\title{
Kernos
}

Revue internationale et pluridisciplinaire de religion grecque antique

$27 \mid 2014$

Varia

\section{Epigraphic Bulletin for Greek Religion 2011 (EBGR 2011)}

\section{Angelos Chaniotis}

\section{(2) OpenEdition \\ Journals}

Electronic version

URL: http://journals.openedition.org/kernos/2266

DOI: 10.4000/kernos.2266

ISSN: 2034-7871

\section{Publisher}

Centre international d'étude de la religion grecque antique

\section{Printed version}

Date of publication: 1 November 2014

Number of pages: $321-378$

ISBN: 978-2-87562-055-2

ISSN: 0776-3824

\section{Electronic reference}

Angelos Chaniotis, « Epigraphic Bulletin for Greek Religion 2011 (EBGR 2011) », Kernos [Online], 27 | 2014, Online since 01 October 2016, connection on 15 September 2020. URL : http:// journals.openedition.org/kernos/2266

This text was automatically generated on 15 September 2020

Kernos 


\title{
Epigraphic Bulletin for Greek Religion 2011 (EBGR 2011)
}

\author{
Angelos Chaniotis
}

1 The 24th issue of the Epigraphic Bulletin for Greek Religion presents epigraphic publications of 2011 and additions to earlier issues (publications of 2006-2010). Publications that could not be considered here, for reasons of space, will be presented in EBGR 2012. They include two of the most important books of 2011: N. PAPAZARKADAS' Sacred and Public Land in Ancient Athens, Oxford 2011 and H.S. VERSNEL's Coping with the Gods: Wayward Readings in Greek Theology, Leiden 2011.

2 A series of new important corpora is included in this issue. Two new IG volumes present the inscriptions of Eastern Lokris (119) and the first part of the inscriptions of Kos (21); the latter corpus is of great significance for the study of Greek religion, as it contains a large number of cult regulations; among the new texts, we single out the 'sacred law of the tribe of the Elpanoridai' in Halasarna. The other corpora present the votive monuments in the Athenian Agora (55), the inscriptions of Andros (101), addenda to the inscriptions of Bostra and the inscriptions of the plain of Nuqrah (114). Among the other publications summarized in this volume we observe an interest in cult regulations (1. 21. 34. 53. 54. 56. 64. 85. 87. 96. 101. 110. 116. 118. 127. 130), the financial aspects of cult (44. 47. 113. 121), and the continuation of pagan worship in Late Antiquity (14. 21. 59. 88. 91. 127. 133. 134). The reader will find in this issue inscriptions that cover all aspects of worship and religious mentality, from expressions of piety to evidence for the neglect of cult. We mention a few interesting texts. A list of ephebes from Tanagra in Boiotia has enriched our knowledge of this city's agonistic culture in the Imperial period (37); the appeal of Greek agonistic festivals among the Roman elite is attested through an inscription from Tarraco in Spain that records victories (of the owner of a villa?) at the Nemea and Aktia (3). An interesting form of divination is revealed through the study of bronze spherulae from Himera (24). An inscription from Limyra in Lykia (136) attests for the first time in Lykia the existence of a Thesmophorion and shows that the cult of Demeter Thesmophoros was introduced in the early Hellenistic period (if not earlier). The salvage excavations for the construction 
of Istanbul's subway have yielded among other interesting finds an inscription that records the dedication of a fishing net, probably to Poseidon (46). An interesting

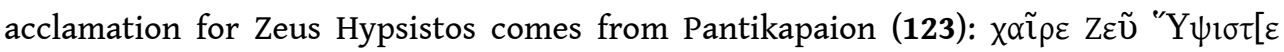

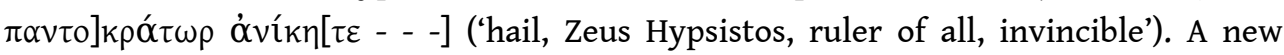
inscription from Itanos on Crete (still unpublished) contains a list of ten girls, members of a chorus that participated in a procession, led by the priestess of Leukothea; the girls should attend the procession in the exact order in which their names appeared on the inscription (130).

3 The principles explained in Kernos 4 (1991), p. 287-288, and Kernos 7 (1994), p. 287, also apply to this issue. Abbreviations that are not included in the list are those of L'Année Philologique and J.H.M. STRUBBE (ed.), Supplementum Epigraphicum Graecum. Consolidated Index for Volumes XXXVI-XLV (1986-1995), Amsterdam, 1999, as well as of later volumes of the SEG. If not otherwise specified, dates are BCE. Jonah Rosenberg (University of Oxford) has improved the English text.

\section{Abbreviations}

$4 \quad$ L'argent dans les concours: B. LE GUEN (ed.), L'argent dans les concours du monde grec, Saint Denis, 2010.

5 La cité et ses élites: L. CAPDETREY, Y. LAFOND (eds.), La cité et ses élites. Pratiques et représentation des formes de domination et de contrôle social dans les cités grecques, Bordeaux, 2010.

6 Epigrammata - Susini: A. INGLESE (ed.), Epigrammata. Iscrizioni greche e communicazione letteraria in ricordo di Giancarlo Susini. Atti del convegno di Roma, 1-2 ottobre 2009, Tivoli, 2010.

7 Late Antique Paganism: L. LAVAN, M. MULRYAn (eds.), The Archaeology of Late Antique 'Paganism', Leiden, 2011.

8 Myths, Martyrs, and Modernity: J. DIJHKSTRA, J. KROESEN, Y. KUIPER (eds.), Myths, Martyrs, and Modernity: Studies in the History of Religions in Honour of Jan N. Bremmer, Leiden, 2010.

Onomatologos: R.W.V. CATLING, F. MARCHAND (eds.), Onomatologos: Studies in Greek Personal Names Presented to Elaine Matthews, Oxford, 2010.

10 Philologos Dionysios: N. BADOUD (ed.), Philologos Dionysios. Mélanges offerts au professeur Denis Knoepfler, Geneva, 2011.

11 Ritual Dynamics in the Ancient Mediterranean: A. CHANIOTIS (ed.), Ritual Dynamics in the Ancient Mediterranean: Agency, Emotion, Gender, Representation, Stuttgart, 2011.

12 Sacred Words: A.P.M.H. LARDINOIS, J.H. BloK, M.G.M. vAN DER POEL (eds.), Sacred Words: Orality, Literacy and Religion, Leiden, 2011.

\section{Index}

\section{Geographical areas (in the sequence adopted by SEG)}

13 Attica: 1. 73. 96. 113; Athens: 16. 30. 42. 55. 64. 83. 85. 105. 113. 118. 128-129. 132. 134; Brauron: 73; Eleusis: 83. 98; Rhamnous: 62. 73. Peloponnese: Corinthia: Corinth: 113. Argolis: Argos: 84. 113. Troizenia:Kalaureia: 131. Epidauria: Epidauros: 84. Messenia: 
Andania: 35; Messene: 10. 12. 36. 122; Pylos: 12; Thouria: 100. Elis: Olympia: 55. 113. Boiotia: 31. 41; Akraiphia: 59. 91; Lebadeia: 88; Tanagra: 37. 88; Thespiai: 9. Aitolia: 86. Delphi: 58. 99. 101. 110. 113. 119. 124. Phokis: 31. Eastern Lokris: 119. Akarnania: Anaktorion: 88. Thessaly: 61. 89. 97; Demetrias: 60. 74; Hypate: 27; Pherai: 109. Epeiros: 26. Illyria: 14; Bouthrotos: 91. Macedonia: Beroia: 95; Chalkidike: 125; Dion: 30; Leukopetra: 36; Thessalonike: 82. 92. Thrace: 48; Augusta Traiana: 25; Byzantion: 46; Constantinople: 46; Philippopolis: 70. Moesia: Tomis: 8. 11. North Shore of the Black Sea: Olbia: 23. 40. 67; Pantikapaion: 123; Tanais: 68. Delos: 21. 82-84. 88. 91. 110. 126. Rhodes: 9; Lindos: 44. Lesbos: Mytilene: 43. Astypalaia: 87. Patmos: 44. Kos: 21. 44. 58. 110. Kalymnos: 44. Naxos: 44. Keos: 127. Andros: 101. Amorgos: 88. Samos: 44. Samothrake: 38. Thasos: 79. Euboia: 82. Crete: 54; Aptera: 81; Idaean Cave: 32. 44; Itanos: 130. Italy: 112; Rome: 36. Sicily: Himera: 24; Tauromenion: 13. 26. Spain: Tarraco: 3. Asia Minor: 22. 72. Karia: Aphrodisias: 39; Attouda: 90; Bargylia: 21. 88; Halikarnassos: 15; Herakleia Salbake: 90; Iasos: 88; Knidos: 110. Phrygia: 90; Tralleis: 58. Ionia: Ephesos: 36. 59. 111; Erythrai: 21. 30; Miletos: 23. Teos: 71. Troas: Ilion: 88. Mysia: Pergamon: 115. Bithynia: Prusa ad Olympum: 6. Paphlagonia: Hadrianopolis: 76; Pompeiopolis: 80. Galatia: Ankyra: 103. Phrygia: Aizanoi: 135; Kelenai/Apameia: 49; Themisonion: 90. Pisidia: Antiocheia: 75. Pamphylia: Sagalassos: 121. Lykia: Limyra: 136. Kommagene: 116. Palestine: 19. Syria: Antiocheia: 65. Kyrenaika: Ptolemais: 108. Egypt: 47. 107; Ptolemais: 30.

\section{Selected topics}

account: 14

acclamation: 3. 19. 34. 36. 104. 114. 121

aesthetic aspects in cult: 98

afterlife: 3. 19. 21. 93. 114

agency: 21.83

agonistic festival: see s.vv. contest, festival

altar: 21. 55. 58. 115. 119; shared: 21.119

amphictyony: 110

amulet: 40. 50.66; see also s.vv. gem, phylactery

ancestral custom: 21.56 ; cult: 21 ; festival: 37 ; tradition: 118

animal, sacrificial: 21. 127. 134; bull: 21; deer: 31; ewe: 21 ; goat: 21. 44; kid: 21; lamb: 21; ox: 21. 127; pig: 21. 127; pregnant: 44; ram: 21; sheep: 21. 127; selection of: 21. 57. 127; yearling: 21

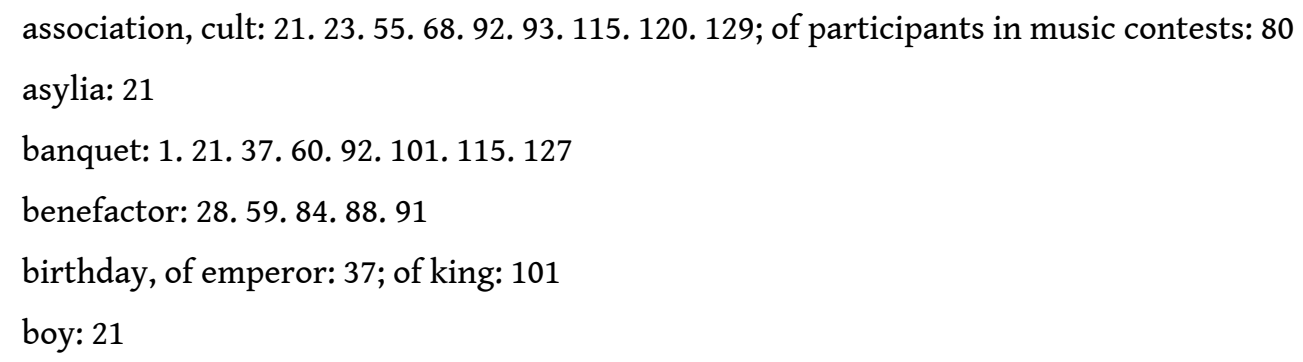


burial practices: 8. 19; funded by association: 92; intra-shrine burial: 83; of newly born babies and fetuses: 87 ; see also funeral, funerary cult

calendar, of Corinthian colonies: 13. 26; festive c.: 21; in Thessaly: 61

cave: 125

chorus: 21.59 .130

Christianity: 44. 47. 113. 114.121; oracle in favor of C.: 44

civic subdivision and religion: 1.21 .55 .96 .105 .110 .133

cleromancy: 24

commemorative contest: 21 ; festival: 36 ; ritual: 21.92

consecration, of sacred place: 21

contest: 21 . 29. 37; bull hunt: 61 ; music contest: 80 ; torch race: 61 ; see also s.v. agonistic festival

crowning: 21

cult, ancestral: 21; exclusion: 45; finances: 21 . 127; interruption of: 98; introduction of: 82. 98. 107. 125; participation in: 21. 98; renewal: 21.44 .59

cult, of deceased family member: 21 ; see also s.vv. heros/heroic cult, imperial cult, ruler cult

cult personnel: agretas 21. 110; archiereus of civic imperial cult: 39. 49.101; archiereus of imperial cult of koinon: 29. 55; agonothetes: 10. 14. 37. 42. 90. 91. 119; archeuon 21; chaleidophoros:10; dadouchos 55; Daliades 21; epimenios 21; epimeletes 55; exegetes 55; Helladarches 29; hestiator 37; hiereia 55. 101. 129. 130; hiereus: 6. 10. 21. 37. 55. 64. 90. 101. 119. 134. 135; hiereus heptaterikos 27; hierokeryx 21. 90; hierophantes 55; hierophylax 21; hieropoios 55. 98. 130. 132; hieropolos 21. 130; hieros 119; hierotamias 21; hierothytes: 10. 100; hypozakoros 55; kanephoros 55. 83; kleidouchos 55; napoiai 21; neokoros 68; paianistes 55; pentameros 119; periegetes 55; phaidyntes 55; pompagogos 130; pyrphoros 55; therapeutes 55; zakoros 55

cult regulation: 1.21 .34 .53 .54 .56 .64 .85 .87 .96 .101 .110 .116 .118 .127 .130

curse: see s.vv. defixio, funerary imprecation

dance: 59

dedication: 69. 79; label on: 22

dedication, motives for: after victory in contest: 55; after victory in war: 16.55 ; upon divine command: 76; in accordance with a dream: 103; in accordance with an oracle: 80; on behalf of emperor: 114 ; on behalf of family members: 114

dedication, agent of: magistrates: 101; magistrates after their term in office: 55.81 .122 ; priest/priestess: 55.90 .101 .119 ; priest/priestess after their term in office: 87 ; soldiers: 89

dedication, object of: anatomical votive: 55; building: 90. 101. 114; cross-torches: 73; ears: 82 ; footprints: 82 ; hand: 122 ; image of one dedicated deity to another: 55 ; painting: 55; one's own statue: 126; wheel: 119

defixio: 18. 40. 43. 46?. 65.112.114. 128

deities: Adrasteia: 101. Agathos Daimon: 21. Aidos: 21. Amphitrite: 14. Aphrodite: 55. 89. 122; Aphrogenes 55; Epekoos 21. 71; Epiteuxidia 92; Kythereia 55; Pandemos 14; Pontia 46. 
Apollo: 21. 41. 44. 55. 90. 118. 119; Agyieus 122; Delios 21. 44. 110; Delphinios 23; Horomedon 21; hyp' Akrais 55; Ietros 23; Ismenios 124; Kendrissos 70; Koropaios 74; Korythos 10; Leukatas 89?; Lykeios 23. 55; Patroios 101; Philios 23; Phyxios 21; Ptoios 59; Pythios 21; Toxophoros 23. Ares: Saprenos 25. Artemis: 31. 44. 55. 73. 86. 89. 101. 119. 122. 126; Akraia 92; Ariste 96; Ephesia 36. 59; Gourasia 92; Iolkia 74; Kalliste 55. 96; Kindyas 21. 88; Koryphasia 12; Limnatis 10; Lochia 87; Phosphoros 89; Soteira 55. Asklepios: 21. 36. 55. 85. 89. 90. 92. 98. 101. 125. 132. Athena: 14. 21. 27. 55. 119; Ergane 55; Ilias 88. 120; Itonia 61; Lindia 21. 44; Mounychia 55; Nike 21; Phratria 55; Polias 21. 55. 101. 105; Soteira 21. Charites: 21. Chiron: 74. Demeter: 21. 55. 58. 73. 76. 83. 98. 101. 119. 121; Chthonia 109; Soteira 58; Thesmophoros 136. Dionysos: 21. 29. 55. 92. 93. 101. 115. 119. 120. 125. 133. 134; Anthios 96; Horophoros 92; Kaprios 89; Kathegemon 115; Megas 101; Sminthios 21. Dioskouroi: 21. Eileithyia: 21. 55. 87. 101. 119; Epilysamena 24. Ennodia: 74. 119. Epione: 21. Eros: 55. Euporia: 55. Ge: 101. Hebe: 55. Hekate: 21. Helios: 9. 21. 80. 93. 101; Basileus 80. Hemera: 21. Hephaistos: 55. Hera: 44. 115. Herakles: 15. 21. 24. 37. 44. 74. 89. 92. 101. 119. 124; Kynagidas 74. Hermaphroditos: 21. Hermes: 15. 21. 37. 101. 119; Chthonios 74. 95; Enagonios 21; Probakchos 21. Hestia: 81; Boulaia 21. 55. 101. Homonoia: 21. 101. Hygieia: 21. 55. 101. 111. Kore: 21. 55. 58. 73. 76. 83. 96. 98. 101. 119. 121; Paphie 55. Korybantes: 115. Kybele: 46. Leukathea/Leukothea: 24. 130. Machaon: 21. Mes: 75. Messene: 12. Meter: Megale: 122;Oreia: 109;Theon: 36. 55. 101. 122. 129. Mnemosyne: 55. Muses: 55. 119. Nemesis: 55. 101. Nike: 21. Nikeros: 21. Nymphs: 11. 85. 101. 125. Pan: 21. 85. Pasikrata: 74. Peitho: 21. Persephone: 114. Plouton: 21. 80. 114. Podaleirios: 21. Poseidon: 14. 46. 58. 92. 122. 131; Apotropos 58; Arges 58; Asphaleios 58; Einalios 58; Erechtheus 105; Gairestios 21; Hippios 58; Isthmios 21; Sosineos 101?; Temenouchos 58. Posphoroi: 55. Priapos: 21. Psithyros: 44. Theoi: Dodeka 21. 55; Katachthonioi 101; Megaloi 38; Pantes 55; Patroioi 21. Theos: Agathe 96; Hagne: 96; Hypsistos 36. 90. 92. Tyche: 114; Agathe 21. Zeus: 14. 21. 58. 80. 101. 114. 122; Akraios 74; Ammon 125; Aniketos 123; Basileus 21; Boulaios 21. 55; Bronton 76; Eleutherios 29. 61; Embaterios 29; Gongylos 92; Horios 21; Hyetios 21; Hypsistos 123; Ithomatas 10; Karaios 27; Karpophoros 101; Kasios 122; Kataibates 21; Kimestenos 76; Kraouandaseon 22; Ktesios 21; Maimaktes 101; Meilichios 55. 101; Nemeios 21; Olympios 29. 61. 97; Ombrios 55; Ourios 21; Pantokrator 123; Patroios 21. 119; Perpheretas 89; Philios 21; Phratrios 55; Polieus 21. 55; Soter 21. 24. 27. 122; Teleios 55 deities, Egyptian: 31. 55. 80. 82. 83. 92. 101. 104. 107. 119; Oriental: Mithras 101; Syrian: Atargatis 87; Dousares 114; Marnas (Zeus) 114; Thracian: Thracian Rider 48. 78. 92.101 deities, assimilation of: 55 (Aphrodite-Kore). 80 (Helios-Zeus-Sarapis). 92 (DionysosZeus Gongylos); eponymous officials: 46; images decorating warships: 21; patrons of fishing: 46; patrons of winds: 110 ; river-god: 68.90

Dionysiac artists: 21. 71. 119. 120

divination: 6.18. 20.24. 33

drama, sacred: 92

dream: 20. 103. 107

earthquake: 58

Eleusinian mysteries: 54. 73. 83. 96. 98

elite: 10. 130; see also s.vv. benefactor, society

emotion: 34. 36; divine anger: 58. 102

endowment: 88. 119; see also s.v. foundation 
ephebes: 29. 55.59

exegesis: 64

exorcism: 18

experience: 36

fate: 3

festival: 35. 127; announcement of: 64 announcement of honors in f.: 21 ; earthquake during f.: 58; funding: 28. 42. 59; interruption of: 59; invitation to: 64 ; order: 34 ; prohibitions: 34; recitals in: 99; see also s.vv. agonistic festival, banquet, procession, sacrifice

festival, agonistic: 8. 14. 35. 106. 119. 120; funding: 28. 77. 84. 88. 91. 119. 120. 133; performances of rhapsodes: 33; prohedria: 90; rewards of victors: 77. 99. 106; Aianteia 120 (Lokris); Aktia 3. 88; Antoneia 29 (Athens); Apollonia 88 (Delos); Asklepieia 21 (Kos). 29 (Epidauros); Basileia 9. 88 (Lebadeia); Demostheneia 35 (Oinoanda); Didymeia 21; Dionysia: 21 (Erythrai, Kos). 29 (Thebes). 42. 133 (Athens). 88 (Iasos). 119 (Opous); Eleusinia 55; Eleutheria 61 (Larisa); Epidauria 55; Epinikia 29 (Athens); Erotidaia 29 (Thespiai); Germanikeia 29 (Athens); Hadrianeia 29 (Athens); Herakleia 29 (Thebes); Hermaia 37 (Tanagra); Isthmia 29; Itonia 88 (Amorgos); Kaisareia 29 (Akraiphia, Athens, Chalkis, Corinth, Epidauros, Gythion, Hyampolis, Lebadeia, Lykosoura, Messene, Patrai, Sikyon, Sparta, Tanagra, Thespiai); Kommodeia 29 (Athens, Sparta, Thebes); Leukophryena 21; Lykaia 29 (Lykosoura); Mouseia 29 (Thespiai); Naia 26; Nemea 3. 9. 29; Nemesia 62 (Rhamnous); Nikephoria 21; Olympia 29 (Athens, Sparta). 97 (Thessaly); Oreionia 37 (Tanagra); Panhellenia 29. 55 (Athens); Philadelpheia 29 (Athens); Posideia 88 (Delos); Ptoa 29; Pythia 90 (Attouda). 99. 124 (Delphi); Rhieia 120 (Physkos); Rhomaia 21 (Kos). 29 (Thespiai); Sarapieia 88 (Tanagra); Sebasta 29 (Athens); Sebasteia 29 (Argos, Demetrias, Echinos, Hypata, Thespiai); Seleukeia 21 (Erythrai); Soteria 99. 101 (Delphi)

festival: Daidala: 35; Hyakinthia: 35; Kynegesia: 37; Thargelia: 118; Thesmophoria: 35.58

finances, sacred: 14. 21.59.84. 88. 91.127.133.134; see also s.v. account

foreigners: 42.43 .92

foundation: 21 ; for cult of family member: 21 ; see also s.v. endowment

founder, of city: see s.v.ktistes; of cult: 75

funeral: 34

funerary cult: 53. 92; see also s.vv. burial, grave

funerary imprecation: 90.102

garden: 21.55

gem: 3; see also s.vv. amulet, phylactery

girl: 130

gladiatorial event: 39.49

grave: 114; protection of: 102

grove: 44

gymnasion: 21.37.93.101. 119

healing: 50.51 .55 .78 ; healing miracle: 90 
hero, heroic cult: 1.21 (Charmylos). 37 (Orion). 55 (heros Iatros, heros Strategos). 67 (Achilleus Pontarches). 78 (Rhesos). 89 (Aineas, Dikaios). 92 (heros Aulonites, Aineias). 97 (Thessalos). 101 (Sosineos, Prophylax?)

Homer: 33.126

humor: 124

hymn: 30.55.58.59. 101

identity: 36.37 .61 .89

impiety: 45

imperial cult: 21.27 .29 .44 .49 .55 .59 .63 .101 .103 .115 .119 ; association with traditional cults: 27. 29; identification of emperor with god: 21 (Claudius-Poseidon). 29 (TrajanZeus Embaterios, Sabina-Demeter); months named after emperors: 37 (Kaisarios)

imprecation, funerary: 90.102

incantation: 50.51

incubation: 21

initiation: 21. 52. 83. 93. 95. 104. 109

incense: 21

invocation: 18.90 .94

ktistes, cult of: 60.74

lamp: 104

lex sacra:see cult regulation

libation: 75

magic: 5. 18. 46. 50. 51. 94. 114; handbook: 50; historiola: 65; image: 46; signs: 40; words: 3. 46. 65; palindrome: 46; resurrection: 94; simila similibus: 65; vowels: 40; see also s.vv. amulet, defixio, exorcism, gem, imprecation, incantation, phylactery

magical papyri: 94

manumission, sacred: 119

miracle: 36 ; see also s.v. healing

music: 124

mystery cult: 36.55 .109 .115 ; see also Eleusinian mysteries, initiation

myth: 33. 119; foundation myth: 8; reenactment of: 92

name, theophoric: 75

night: 73. 96; see also s.v. lamp

norm, ritual: 34.53

numeral: 23

oath: 21.36

oracle: 20.44 .80

orality: 64

Orphism: 3. 50. 52.72.95. 109

paganism in Late Antiquity: 44.113. 121 
personification: Aidos: 21; Euporia: 55; Hemera: 21; Mnemosyne: 55; Psithyros: 44

phylactery: 72; see also s.v. amulet

piety: 21.36. 83; see also s.v. impiety

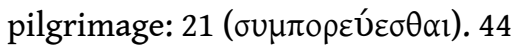

politics: 62.98 .116

prayer: 21.34 .64 .75 .118

priesthood: 83. 96. 116; appointment by lot: 21. 105. 129; financial duties: 134; of genos: 105; for life: 55; funds for: 21; iteration: 129; in Late Antiquity: 44; perquisites: 96.110 ; ritual expertise: 64; sale of: 21; tax exemption: 135

procession: 21. 29.59. 98. 101. 104. 130; arrangement of: 34.118 .130

punishment, divine: 45.87 .102

purification: 55

purity: 21.87 ; of the mind: 44

Pythais: 55

rhapsodes: 33

rituals, change of: 34.53 .59 .83 .98 .118 ; inroduction of: 34 ; neglect of: 21 ; see s.vv. acclamation, banquet, birthday, crowning, cult, dance, drama (sacred), exorcism, festival, hymn, incubation, initiation, incantation, invocation, libation, magic, norm, oath, pilgrimage, prayer, procession, Pythais, rosalia, sacrifice, taurobolium, theoria, vow

river-god: 68.90

rosalia: 92

ruler cult: 21 (Ptolemy I, Arsinoe II, Nikomedes). 34 (Antiochos III, Laodike). 62 (Antigonos Gonatas). 71 (Berenike Thea, Arsinoe Thea, Kleopatra Thea). 74 (Demetrios Poliorketes, Antigonos Gonatas). 115 (Attalos I)

sacrifice: 1. 21. 29. 31. 57. 58. 60. 69. 96. 110. 127. 129. 134. 135; consumption of sacrificial meat at the spot: 21.110 ; decline of: 44 ; glamour of: 21 ; hekatomb: 21 ; funds for: 21 ; raw meat: 96 ; requested by an oracle: 80 ; sacrifice to a god in a sanctuary of another: 21; selection of victims: 21 ; see also s.v. animal (sacrificial)

sanctuary: 21; boundary marker: 85 . 101. 122; decoration of: 21 ; federal: 61 ; funds: 21 . 84. 88. 91; network of: 116; order in: 21.129 ; protection of: 21.101 ; recipient of fine: 21 ; see also s.vv. account, finances

scepter: 102

secrecy: 109

society: 53. 130; see also s.vv. benefactor, elite, foreigner, women

soul: 3

statue: 21.86 ; decoration of: 21 ; dressing of: 119 ; transport of: 44

taurobolium: 113

temple, dedication of: 76. 90; in Late Antiquity: 44. 47. 121; conversion: 44. 121; destruction: 47.113.121

theocracy: 116

theoria: 21. 101. 110; see also s.v. Pythais 
throne: 21

torch: 96; torch-race: 21

treasure-box: 100

vow: 22. 25. 48. 55. 64. 87. 90

water: 85.125

wedding: 126

women: 21.73 .79 .83 .87 .126

\section{Greek words (a selection)}

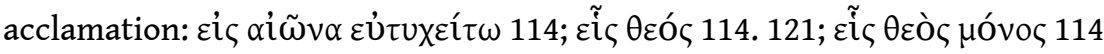

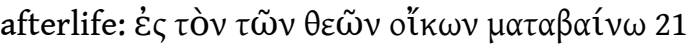

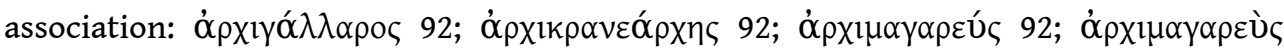

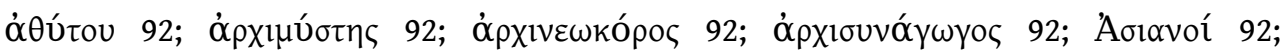

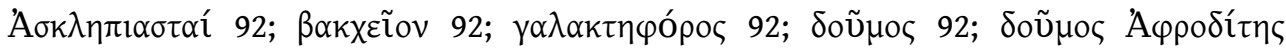

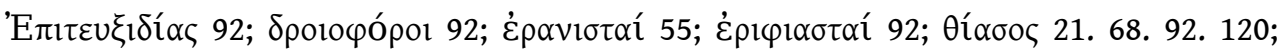

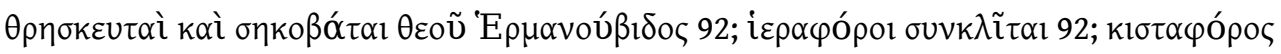

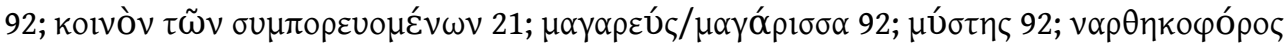

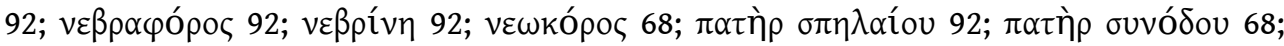

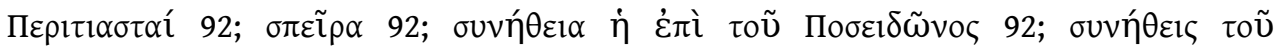

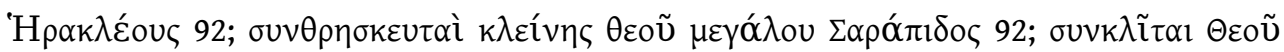

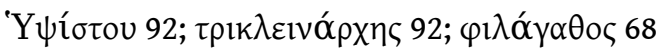

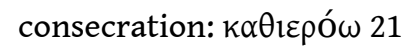

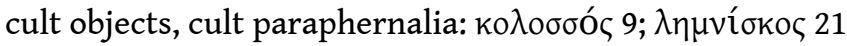

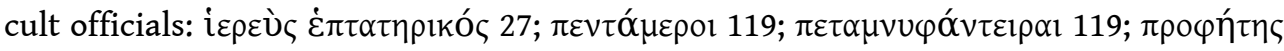

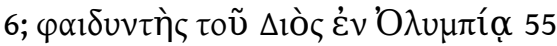

cult regulation: i̇рòৎ vópoৎ 21

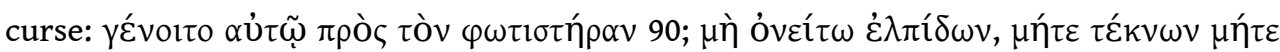

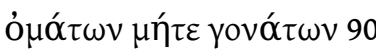

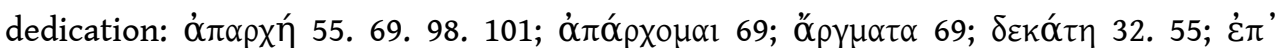

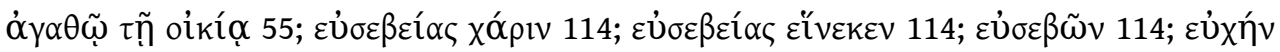

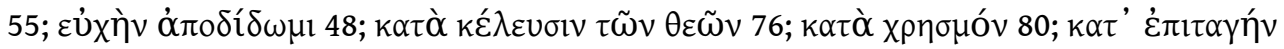

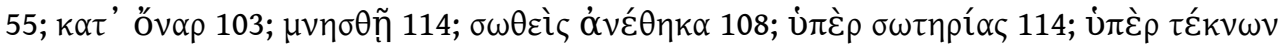

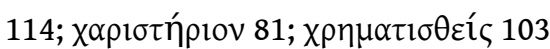

5 dedicatory object: à

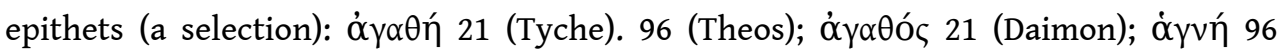

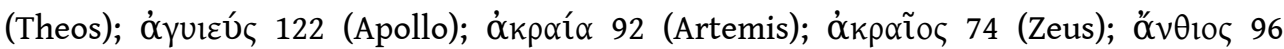

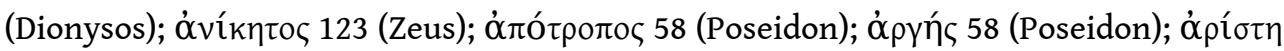

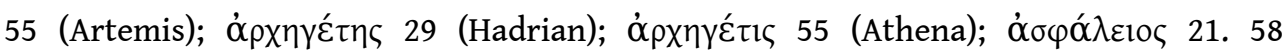

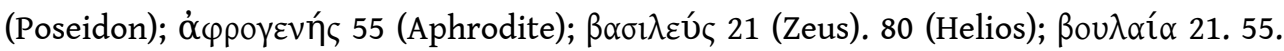

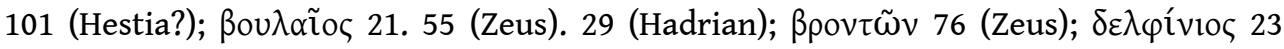

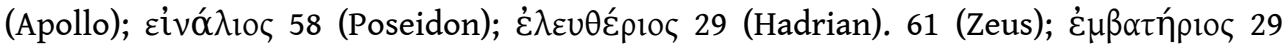

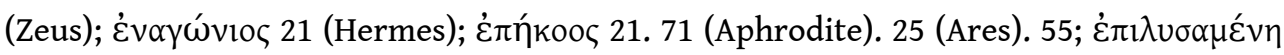




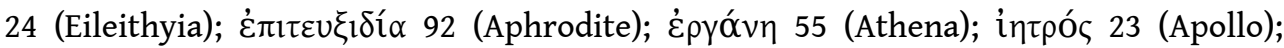

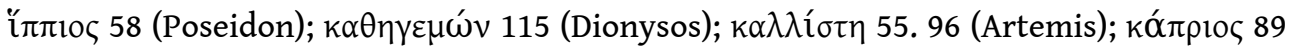

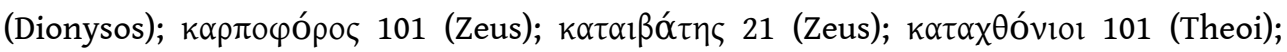

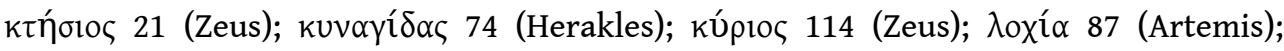

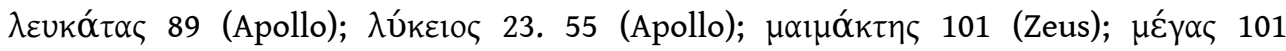

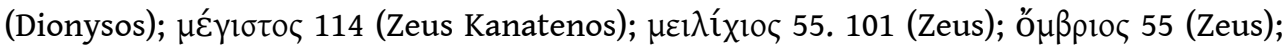

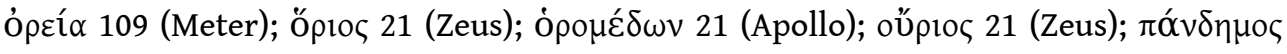

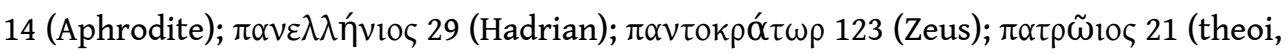

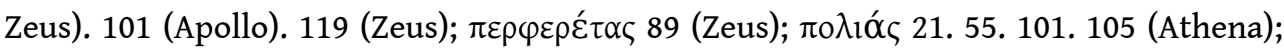

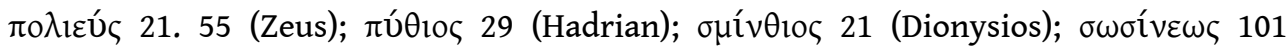

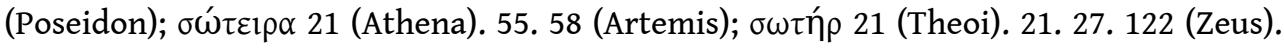

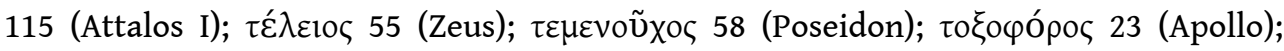
ن́ć

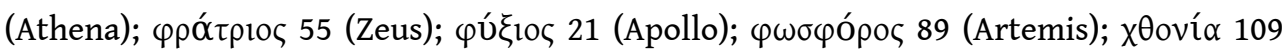

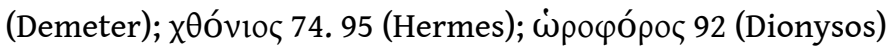

1) D. ACKERMANN, "Un nouveau type de communauté attique. Les pentékostyes du dème d'Aixônè", in Philologos Dionysios, p. 40-78: The cult regulation from Aixone (ca. 400-375; SEG LIV 214; EBGR 2004, 256; 2010, 1-2) attests for the first time pentekostyes in Attica. In Aixone, they offered sacrifices to heroes, providing the food-stuff for the sacrifice

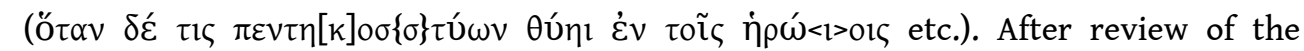
evidence for 'divisions numériques' in the Greek world (especially in Doric areas), A. proposes to interpret the pentekostyes in Aixone and the triakades in Piraeus (IG II ${ }^{2} 1214$ ) as remnants of early civic subdivisions, possibly military in nature. After the reforms of Kleisthenes, such subdivision no longer fulfilled a function as the basis for the 
organization of the citizen-body and the army, but some larger demes retained them in order to structure their population in a better way; they played a part during sacrificial banquets.

2) M. ALONGE, "Greek Hymns from Performance to Stone", in Sacred Words, p. 217-234: After examining in detail the context of inscribed hymns (the paian of Philodamos and Aristonoos in Delphi, Sophocles' hymn to Asklepios, the hymn of Palaikastro to Zeus), A. convincingly argues that the hymns were not inscribed in order to aid future performance but to commemorate a particular performance - the composition and first (and only?) performance or a revived performance (Sophocles' paian in the Imperial period) - or in order to be displayed and reasses local traditions (the reinscribing of the Palaikastro hymn in the 3rd cent. CE).

3) G. ALFÖLDY, "Griechische Inschriften und griechische Kultur in Tarraco", ZPE 178 (2011), p. 87-125: A. collects the Greek inscriptions of Tarraco and discusses their significance as evidence for the penetration of Greek culture in this city; the texts are now also included in the corpus of Tarraco $\left(C I L \mathrm{II}^{2} .14\right)$. The texts include a partly

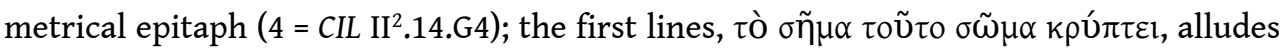
to the Orphic-Pythagorean concept of the body $(\sigma \tilde{\omega} \mu \alpha)$ as the grave $(\sigma \tilde{\eta} \mu \alpha)$ of the soul (3rd/4th cent.). A graffito on a wall-fresco has the magical formula $\varphi \circ \rho \beta \alpha \varphi \circ \rho \beta \eta(12=$ CIL $\mathrm{II}^{2}$.14.G12, Imperial period). A gem with the representation of a lion and the

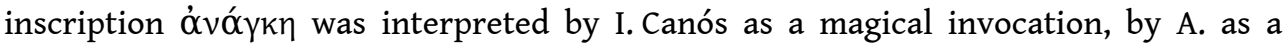
reference to the fatum, the unalterable fate of humans [to judge from the photo, the represented figure is not a lion but a winged figure with a wreath and a distaff or torch]. A painted inscription on a wall-fresco of the villa of $C$. Valerius Avitus is read by

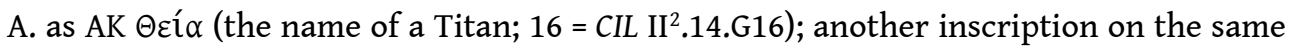
wall-fresco names the Nemean festival ( $17=$ CIL II ${ }^{2} .14 . G 17$ : Nع́ $\mu \varepsilon 1 \alpha$, ca. $\left.150 \mathrm{CE}\right)$; the finds from the villa show the owner's interest in Greek culture. [As C. KRITZAS, "A Greek Inscription from Tarraco (CIL II ${ }^{2} / 14,2$ G16)", ZPE 181 (2012), p. 88-90, has shown, the

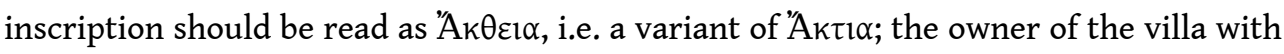
the fresco had been a winner at the Aktia and Nemea]. A bilingual epitaph for an imperial freedman $\left(18=C I L \mathrm{II}^{2} .14 . \mathrm{G} 18\right.$, late 2 nd cent. CE) begins with a Greek acclamation: [- -]TI $\varphi \tilde{\omega} \varsigma \Lambda \imath \tau o p i ́ o v ;$ Litorius was the freedman's supernomen. After

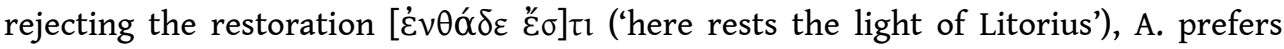

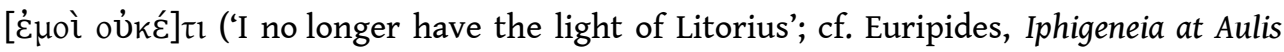
1281f.) [in view of the widespread idea that the deceased became a star (eg. IG XII. 7.123), also attested in the freedmen milieu (e.g. SEG XXXI 846), another possibility

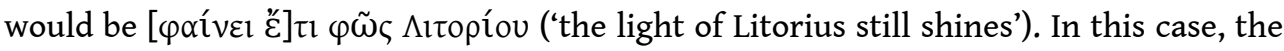
acclamation was not an expression of grief but of consolation].

4) W. AMELING, "Der kleinasiatische Kaiserkult und die Öffentlichkeit. Überlegungen zur Umwelt der Apokalypse", in M. EBNER, E. ESCH-WARMELING (eds.), Kaiserkult, Wirtschaft und Spectacula. Zum politischen und gesellschaftlichen Umfeld der Offenbarung, Göttingen 2011, p. 15-54: Drawing on a large number of inscriptions, A. presents an excellent overview of the various ways in which the imperial cult was visible in the cities of Asia Minor especially. He discusses inter alia the naming of months after emperors, the presence and use of statues of the emperor, the existence of cult associations devoted to the emperor, the private cult of the emperors (domestic altars, prayers, vows, private sponsoring of imperial temples), the civic imperial cult and the occasions for regular and extraordinary celebrations, the 'provincial' cult, and the festivals for emperors and 
their rituals (sacrifices, hymns, orations, venationes, munera). A. stresses that the imperial cult attracted large audiences but did not present a threat to Christianity as is assumed by some studies on the Apocalypse.

181 5) M. ANDREASI, “Implicazioni magiche in Meleagro AP 5.152”, ZPE 176 (2011), p. 69-81: With his epigram AP 5.152, Meleager asks a mosquito to go to his lover Zenophila, wake her, and bring her to him. A. recognizes connections with magical practices, elaborating on K. Gutzwiller's idea that the poem recalls the 'insomnia spell' (see EBGR 2010,73 ). A. discusses the presence of the same subjects (messenger, flight, whisper, insomnia, sleep, oblivion, erotic rivalry, exortation, reward for bringing someone) in this poem and in magical texts.

182 6) M.-F. AUZÉPY et al., "Campagne de prospection 2007 de la mission Marmara", Anatolia Antiqua 16 (2008), p. 413-442 [SEG LVIII 1451; An.Ép. 2008, 1311]: Ed. pr. of a building

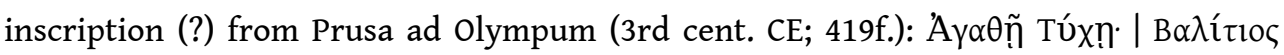

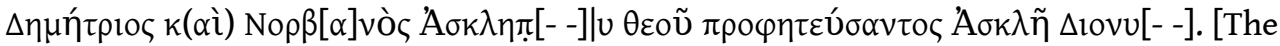
character of the text cannot be determined. It seems that $\pi \rho \circ \varphi \eta \tau \varepsilon \cup \sigma \alpha \nu \tau o \zeta$ refers to Askles. There are several possibilities for the first part of the inscription. The two

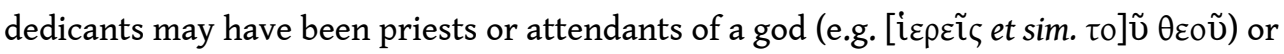

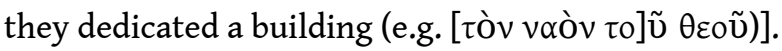

183 7) A. AVRAM, "Sur quelques noms d'Apollonia du Pont", in Onomatologos, p. 368-380: Several names known in Apollonia Pontica, such as names in -themis and -mandros, names deriving from religious practices (cf. names in $\mu \circ \lambda \pi$ - connected with the cult of Apollo), and theophoric names (Letodoros), show that the onomastic material was primarily determined by the Milesian origin of the colonists.

184 8) A. AVRAM, C.P. JONES, “An Actor from Byzantium in a new Epigram from Tomis", ZPE 178 (2011), p. 126-134 [BE 2012, 301-302]: Ed. pr. of a grave epigram from Tomis (ca. 150-200 CE), dedicated to Euelpistos, an actor from Byzantion, who had won dramatic

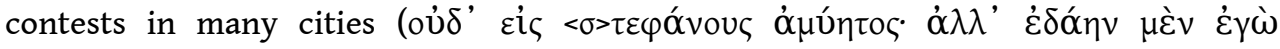

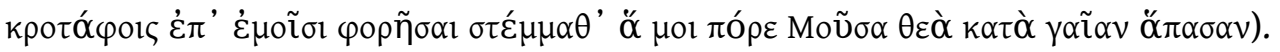
His grave was near a vineyard: 'I dwell in the tomb, in my own lovely plot, within the flowery plot where the beauteous tendrils of Bacchus (are).' The first verses make mythological allusions to Byzas, a descendant of Inachos, king of Argos, the father of Io (FGrHist 390 F1), and to Tomos, the eponymous founder of Tomis: Eivoxías yoí $\alpha \varsigma$

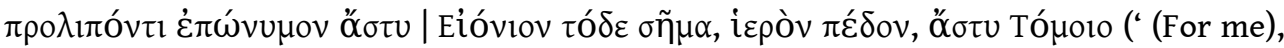
when I abandoned the city named for the Inachian land, that of Io, this tomb, holy ground, (was) Tomus' city') [but G. STAAB, infra $n^{\circ} 117$, proposes a different reading

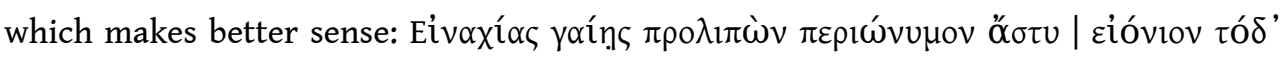

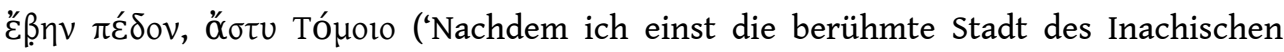
Landes verlassen hatte, kam ich in diese am Meer liegende heilige Ebene, hier, die Stadt des Tomos'); in this reading, the text does not refer to the myth of Io].

9) N. BADOUD, "Les colosses de Rhodes", CRAI (2011), p. 111-150 [BE 2013, 36, 169]: B. discusses the history of the statue of Helios constructed by Chares (ca. 295-283) and destroyed in ca. 227, the alleged attempts to reconstruct it in the Imperial period, the later legends concerning its remains, the sculptor and his work, and the possible appearance of the statue [on this subject, see id., "L'image du colosse de Rhodes", Mon.Piot 91 (2012), p. 5-40]. In this context, he discusses the various interpretations

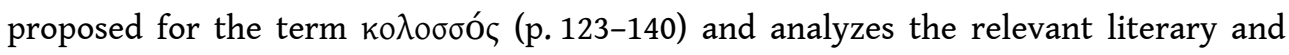


epigraphic sources. He plausibly argues that at the time of the Colossus' construction, in the 3rd cent., the term designated "un type particulier de statue immobile, destinée à fixer en elle un être qui lui était extérieur". It was only after the destruction of the Colossus (ca. $227 \mathrm{BCE}$ ) that the word acquired the meaning of an over-sized image. He further argues that this type originates in the Peloponnese and was diffused in the areas of Dorian colonization. An emblem on Rhodian amphora stamps (ca. 235-198), showing a head with sunrays on a long stem, may be a representation of this statue (p. 140-144). B. also republishes a dedicatory epigram from Thespiai, which records the dedication of a kolossos (a statue of normal dimensions) by a victor (athlete or artist?) at the Basileia and the Nemea (I.Thespiai 333; an improved edition: SEG XXIV 362, late 3rd cent.; p. 146-149).

10) D. BALDASSARA, "Osservazioni prosopografiche sulle famiglie messenie dalla dinastia flavia al III secolo d.C.", in La cité et ses élites, p. 119-144: Continuing her studies on elite families in Messene in the Imperial period [cf. EBGR 2010, 11], B. examines the family relations between prominent Messenians who occupied important offices or were honored for their services. In this context she examines the prosopography of men who occupied religious offices during the Flavian dynasty (priest of Zeus Ithomatas, agonothetes, hierothytai, chaleidophoros, priestess of Artemis Limnatis, priest of Apollo Korythos; p. 125-129) and several families, whose members excelled in public activities occupying offices in the city and the province in the 2nd and 3rd cent. CE, including religious offices (hierothytai, agonothetai, priests).

11) M. BăRBULESCU, L. BozoIANU, "Inscriptions inédites et révisées de la collection du Musée d'Histoire Nationale et d'Archéologie de Constantza. II", Pontica 43 (2010), p. 347376: Ed. pr. of a dedication found at Valea Seacă (area of Tomis), probably addressed to the Nymphs (p. 361-367 n ${ }^{\circ}$, 2nd cent. CE).

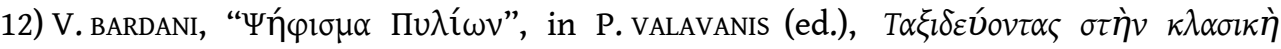

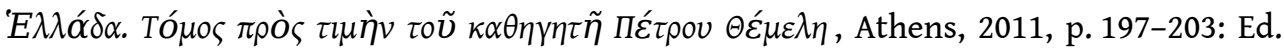
pr. of an honorific decree of the Pylians for a man from Messene (Messene, 1st cent.). The inscription was set up in the sanctuaries of Athena Koryphasia in Pylos and that of Messene in Messene. The honorand was to be crowned at the Dionysia in Messene and

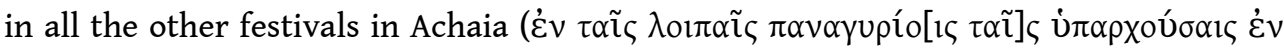
Axoî $\alpha$ l) in that year.

13) F. BAtTistoni, "Time(s) for Tauromenion: The Pilaster with the List of the Stratagoi (IG XIV 421) - The Antikythera Mechanism", ZPE 179 (2011), p. 171-188: B. examines the evidence provided by the Antikythera mechanism for the calendar of Tauromenion (p. 182-184). He observes that the correct form of a Tauromenian month hitherto read

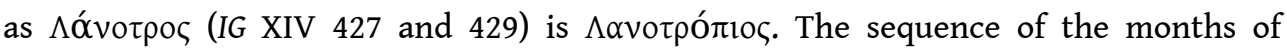
Tauromenion is known; six of them are the same as the months of the calendar used in the mechanism [marked with an asterisk]; the remaining six months have different names [we give the names of the corresponding month in the mechanism in parenthesis]: Artemisios*, Dionysios (Psydreus), Hellokios (Gameilios), Damatrios (Agrianios), Panamos*, Apellaios*, Itonios (Phoinikaios), Karneios*, Lanotropios*, Apollonios (Machaneus), Duodekateus*, Eukleios*. It seems that both calendars had intercalary months, Eukleios in the mechanism, Apellaios in Tauromenion. B. suggests that months with the same name corresponded to different months of the solar year. [When calendars have only small similarities and are of different origins, it can be expected that homonymous months hold different positions in the solar year; not in 
calendars so closely related as the calendar of the mechanism and that of Tauromenion; see also infra $\left.{ }^{\circ} 26\right]$.

190 14) V. BERETI, F. QUANTIN, P. CABANES, "Histoire et épigraphie dans la région de Vlora (Albanie)", REA 113 (2011), p. 7-46 [BE 2012, 36]: The authors study the history and topography of the area of the gulf of Vlora (Aulon) in southern Illyria, collecting the relevant epigraphic evidence (including some inedita, mainly epitaphs). The most important epigraphic finds are from Ploçe (Amantia) and its area. Three inscriptions concern the cult of Aphrodite Pandemos (p. 23-25 $\mathrm{n}^{\text {os }} 10-12$ ). The cult is attested through two dedications (SEG I 265; L.M. UGoLINI, Albania Antica I, Rome-Milan, 1927, p. $195 \mathrm{n}^{\circ}$ 16; 1st - 2nd cent.) and a building inscription recording repairs in an Aphrodision (UGoLINI, op. cit. p. 195f. $\mathrm{n}^{\circ} 17$; 2nd cent.). Another inscription from this area (p. 26f. $\mathrm{n}^{\circ} 13$ ) is only know from an inaccurate copy made by S. ANAMALI, Iliria 2 (1972), p. 91 (cf. $B E 1973, n^{\circ} 261$ ). The text is a decree of the council referring to the account

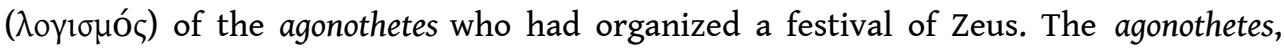
Nikaios, reported that he had received from Lysanias, a benefactor, an amount for this

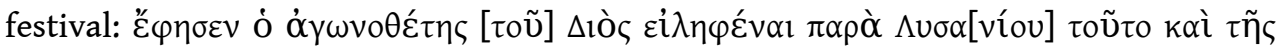

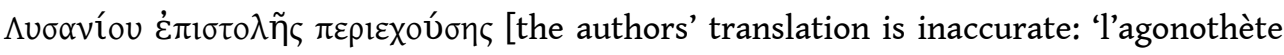
de Zeus a dit avoir reçu cette somme de Lysanias et le message de Lysanias le concernant'; correct: 'the agonothetes of Zeus stated that he had received (a sum) from Lysanias, and this is (also) the content of Lysanias' letter']. The council approved of an

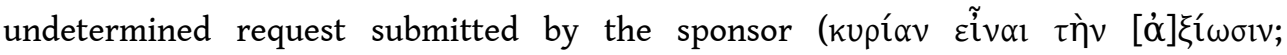
$[\dot{\alpha}] \xi ı \omega$ veıv in Anamali's copy). It seems that the sponsor had pointed out that he had

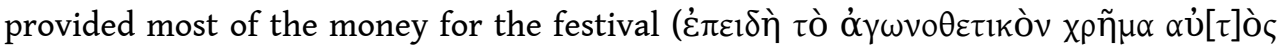
$\dot{\varepsilon} \chi \alpha \rho i ́ \sigma \alpha \tau o)$, whereas Nikaios had only spent 600 denarii, as was written in his account;

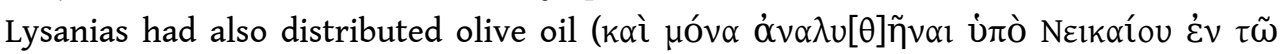

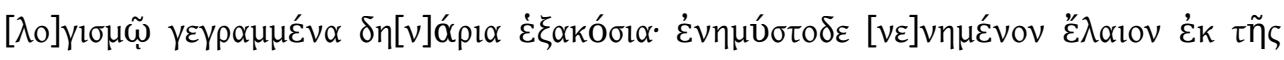

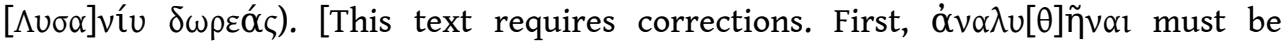

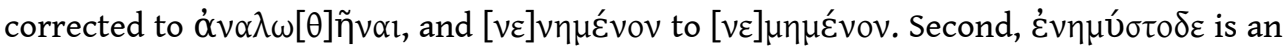

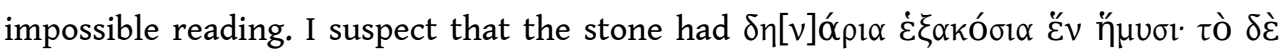

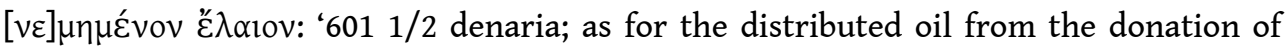
Lysanias, etc'. That the council approved of Lysanias' request implies a conflict between Nikaios and Lysanias, possibly for the credit of having organized the agonistic festival.] Finally, there is a dedication to Poseidon and Amphitrite (SEG XXXIX 553; p. 28f. $\mathrm{n}^{\circ} 15$ ).

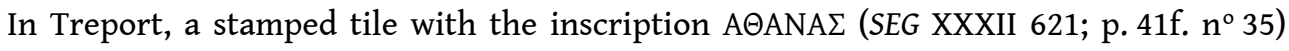

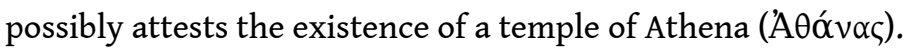

191 15) B. BERKAYA, S. ISAGER, P. PEDERSEN, "The Stadion of Ancient Halikarnassos", in P. PEDERSEN (ed.), Halicarnassian Studies V, Odense, 2008, p. 137-155 [SEG LIX 1201]: The authors present fragments of inscribed blocks from the stadion of Halikarnassos (late Hellenistic). The text, probably a dedication made by a certain Philokles, is very fragmentary. It may have been a dedication to Herakles and Hermes.

192 16) S. BERTI, "La dedica degli Ateniesi per la vittoria su Beoti e Calcidesi del 506 a.C. (IG I ${ }^{3}$ 501) e la data del suo ripristino", Aevum 84 (2010), p. 7-40 [BE 2011, 177]: B. discusses in detail the literary and epigraphic tradition concerning the dedication made by the Athenians on the Acropolis after their victory over Boiotians and Chalkidians (506 BCE). After its destruction by the Persians in $480 \mathrm{BCE}$, the monument was re-erected and the dedicatory epigram re-inscribed, with changes in the sequence of the verses. Various dates have been proposed for the re-dedication (457, 454, 446, or $431 \mathrm{BCE})$. Considering 
the political context, B. endorses the view that the renewal of the dedication was made after the victory of the Athenians at Oinophyta in 457 BCE. Cf. id., 'The Athenian Victory Over the Boeotians and the Chalkidians (506 B.C.) in the Light of the Epigraphical Findings', AHB 24 (2010), p. 3-23, for a discussion of the historical context.

17) G. BevilaQUA, "Due nuovi amuleti contro il mal di testa e altre malattie da Capua", Orizzonti 12 (2011), p. 37-49: After an introduction to amulets used for healing purposes, B. presents two new phylacteries written on silver sheets (Capua, 4th/5th cent.). The first text, written in bad Greek invokes the Christian God against evil spirits, diseases,

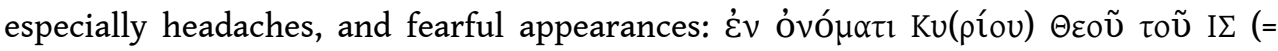

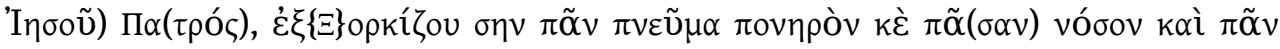

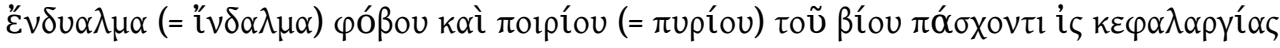

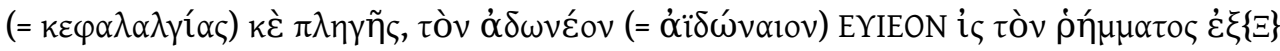

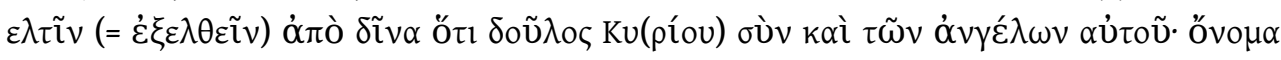

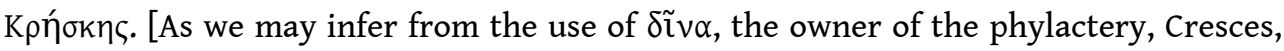
was copying a formula, in which he should have replaced $\delta \tilde{v} \alpha \alpha$ with his own name]. The second phylactery consists of a sheet rolled within a bronze cylinder. The provenance is unknown (kept in the Archaeological Museum in Naples) but the similarity of content

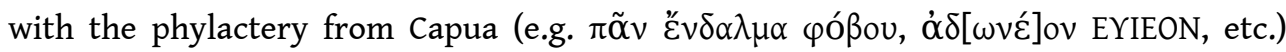
suggests the same provenance.

18) G. Bevilacqua, G. VAlLARINo, M. Centrone, A. Viglione, Scrittura e magia. Un repertorio di oggetti iscritti della magia greco-romana, Rome, 2010 [BE 2012, 67]: This volume presents a representative collection of inscribed objects related with ancient magical practices (defixiones, love magic, protective magic, invocations, exorcism, divination). After two introductory essays by BEVILACQUA, who discusses ancient magical objects and the connections between magic and writing (p.13-20), the largest part of the volume is dedicated to magical practices ('la magia applicata', p. 21-82), in accordance with a typology of inscribed magical objects proposed by VALLARINO. He distinguishes between 'semplici supporti' (objects of metal, stone, selenite, clay, papyrus, wood, linen, and parchment) and 'oggetti autonomi' ('voodoo dolls', nails, jewels, pendants, lamps, tintinnabula, various divinatory devices, pinakes, vases, boxes, books). For each category examples are presented (Greek text and Italian translation). Additional essays cover the following subjects: the writing of magic (by BEVILACQUA, p. 83-85); making words invisible (by VALLARINo, p. 87-94); the layout of the inscribed text on the object, i.e. lists, columns, arrangement of words in the shape of objects, use of images, etc. (by CENTRONE, p. 95-117) [cf. EBGR 2010, 43]; images in magical text (by VIGLIONE, p. 119-131). This selection of essays and a large number of representative objects is an excellent introduction to the study of magic.

19) L.H. BLummel, "A Gold Lamella with a Greek Inscription in the Brigham Young University Collection", ZPE 177 (2011), p. 166-168 [BE 2012, 73]: Ed. pr. of a gold lamella, probably originally from Palestina, where similar objects have been found (Imperial

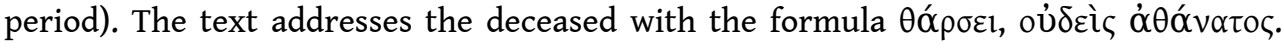
The text offered consolation or, rather, gave courage to the deceased individual in his underworld journey [why not both? Such phrases may originate in acclamations during the funeral].

20) P. BonNeChere, "Oracles and Greek Mentalities: The Mantic Confirmation of Mantic Revelations", in Myths, Martyrs, and Modernity, p. 115-131: B. discusses the interesting phenomenon of Greeks, both publicly and privately, seeking to confirm an oracle or 
sign through additional divinatory consultation. Such cases, attested by literary and epigraphic sources include the request of Agesipolis to Apollo in Delphi to confirm an oracle of Zeus in Olympia (Xenophon, Hellenika 4.7.1-3; Aristotle, Rhetorika 1398b; for a manipulation of an oracular response cf. IG $\mathrm{II}^{2} 204$ ); multiple consultations of the same oracle; the waiting of favorable signs prior to the consultation of an oracle; the confirmation of signs by other signs (IG IV $2.1 .122 \mathrm{~B} 13$ ); the reception of repeated signs and prophetic dreams; repeated oracles (e.g. I.Magnesia 16) [cf. EBGR 2007, 134]; massive appearances of epiphanic dreams (I.Didyma 495).

21) D. BOSNAKIS, K. HALLOF, K. RIGSBY, Inscriptiones Graecae Insularum Maris Aegaei praeter Delum. Fasciculus IV. Inscriptiones Coi, Calymnae, Insularum Milesiarum. Pars I. Inscriptiones Coi Insulae. Decreta, epistulae, edicta, tituli sacri, Berlin, 2010 [BE 2011, 472; 2013, 334]: Hardly any other place in Greece, with the exception of Attica, offers so many inscriptions of religious interest as Kos. The publication of the first part of the corpus of the Koan inscriptions, which assembles the known texts, often with improved readings and restorations, and adds some new ones (marked with an asterisk), should, therefore, be greeted as a great contribution to the study of Greek religion; it has already been exploited by S. PAUL, Cultes et sanctuaires de l'île de Cos, Liège, 2013. The first volume (the second appeared in 2012) presents 423 texts: decrees (1-206), documents concerning the asylia of the sanctuary of Asklepios (207-245), letters (246-263), senatus consulta and edicts (264-273), documents of religious content (274-396), and altars (397-423). We do not summarize the content of many texts that have already been presented in EBGR 1993/94, 219 (IG XII.4.78-80, 122, 166, 269, 290-291, 350-354), EBGR 1998, 111 (IG XII.4.70, 93, 123, 143, 148, 176), EBGR 2001, 139 (IG XII.4.81, 94, 294-295), EBGR 2003, 18 (IG XII.4.69), EBGR 2004, 140 (IG XII.4.91, 95, 358), and EBGR 2008, 20 (IG XII. 4.254-257). Cult regulations: Most cult regulations ('leges sacrae') and similar texts (regulations concerning the sale of priesthoods) have been included in F. Sokolowski's Lois sacrées ( LSCG $150 \mathrm{~A}=283 ; 150 \mathrm{~B}=\mathbf{2 8 4} ; 151 \mathrm{~A}=\mathbf{2 7 7 - 2 7 8 ;} ; 151 \mathrm{~B}=\mathbf{2 7 4} ; 151 \mathrm{C}=\mathbf{2 7 6} ; 151$ $\mathrm{D}=\mathbf{2 7 5} ; 152=\mathbf{2 8 5} ; 153=\mathbf{2 8 2} ; 154=\mathbf{7 2} ; 155=\mathbf{7 1} ; 156=\mathbf{3 3 2} ; 157=\mathbf{3 3 2} ; 158=\mathbf{2 8 8} ; 159=$ 286-287 [two copies of the same text]; $160=\mathbf{3 1 8} ; 161=325 ; 162=\mathbf{3 1 1} ; 163=\mathbf{3 3 0} ; 164=$ 342; $165=\mathbf{2 8 1} ; 166=326 ; 167=327 ; 168=293 ; 169 \mathrm{~A}-\mathrm{C}=\mathbf{2 8 0} ; 170=359 ; 171=\mathbf{3 4 9} ; 172=$ 303; $173=\mathbf{1 0 3} ; 174=\mathbf{3 6 5} ; 175=\mathbf{3 5 6} ; 176=\mathbf{3 3 3} ; 177=\mathbf{3 4 8}$ ). Several texts have been presented in EBGR 1993/94, 219 (80, 334-339, 343, 345-347, 350-353, 367-368, 379-382), 2001, 139 (81, 294-295), and 2004, $140(91,358,364)$. We only summarize new texts and texts not included in the aforementioned publications. A small fragment, written by the same mason as LSCG 158 (cult regulation concerning Asklepius' temple), possibly concerns the establishment of the Asklepieia (289, ca. $242 \mathrm{BCE})$. One recognizes the dedication of an object [a phiale?] to Asklepios; prayers to be made by the priest and

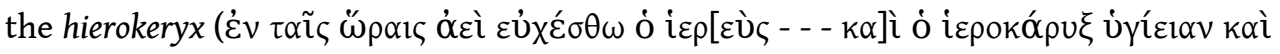
$\sigma \omega \tau \eta \rho i ́ \alpha[v--])$; the establishment of an athletic and musical contest ( $\dot{\alpha} \gamma \tilde{\omega} v \alpha \delta \delta \dot{\varepsilon} \tau \imath \theta \dot{\varepsilon} \tau \omega$

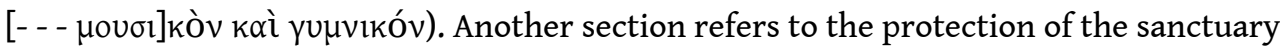

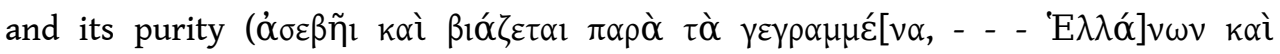

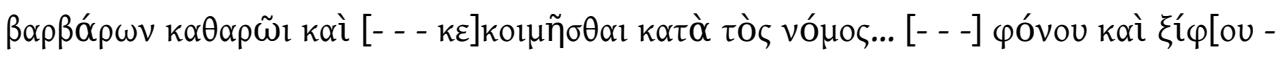
-]) [since the text concerns the Asklepieion, where incubation was practiced,

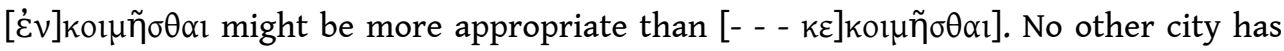
such a large group of regulations concerning the sale of priesthoods (296-324; cf. *383); they have been summarized in EBGR 1993/94, 219; 2001, 139; and 2005, 20. In two cases, inedita present further copies of already known sales of priesthoods: that of Homonoia (*324, early 1 st cent.; the other copy is earlier, dating to the 2 nd cent.: 315$)$ and that of 
Hermes Enagonios $\left({ }^{*} 331\right.$; two further copies: 298 and 307). Two new fragments do not contain the name of the priesthood $(* 300, * 313)$. From Kos we have detailed evidence for the agonistic and religious life of the gymnasion (see EBGR 1993/94, 219 and $1994 / 95,143)$. To this evidence, the corpus adds a new small fragment with regulations concerning contests, processions, and sacrifices in the gymnasion $\left({ }^{*} 292\right.$, ca. 150 BCE; cf. 298 and 308); an interesting detail is the mention of $\Delta \alpha \lambda \imath \alpha$ ó $\delta \alpha$, i.e. choruses of girls to be sent to Delos [I. RUTHERFORD, infra $\mathrm{n}^{\circ} 110$, p. 673f. with note 72 , distinguishes between the Daliadai and the $\dot{\alpha} \gamma \rho \varepsilon \tau \alpha i$, group of women possibly with an initiatory dimension]. A fragment deals with order in the sanctuary (*340, ca. $150 \mathrm{BCE})$. It stipulates that there

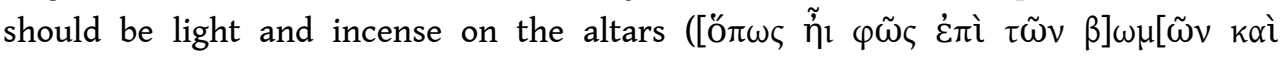
$\left.\dot{\varepsilon} \pi \imath \theta_{\mu} i \tilde{\eta} \tau \alpha 1\right]$ ] [probably not light but fire: e.g. [ö $\left.\pi \omega \varsigma \tilde{\hat{\eta}} 1 \pi \tilde{u} \rho\right]$ ]; fines should be paid for acts of injustice under responsibility of the hierophylakes; animals caught pasturing in the sanctuary should be sacrificed. Another small fragment provides instruction for the appropriate crowning [of statues or altars?] (341, 2nd cent.). Numerous small fragments (370-378, 383-384, 386-390) do not provide significant information; one only recognizes references to sacrifices $\left(*^{*} 370, *_{387} *_{389}\right)$ and gods (Zeus Soter and Athena Soteira: ${ }^{*} 370$; Asklepios: ${ }^{*} 371, *^{*} 378$; Dionysos: $\left.{ }^{*} 389\right)$. Three important texts provide information for the religious life in the Koan demes and civic subdivisions. An octagonal column, inscribed on five sides, contains the festive calendar of the deme of the Phyxiotai on three of its sides (279 A-C, 3rd cent.). Hardly anything is preserved on side A. Sides B/C list sacrifices that were to be offered on specific days, as follows: 1) Anonymous month (Petageitnyos?): on an unknown day, to an unknown goddess, a grown goat; to Athena, a grown goat and another grown animal; 12th day, to Apollo a grown victim, to Epione a goat, to Dionysos a kid or a he-goat or a grown sheep on the altar of the Symmachidai. 2) Kaphisios: 12th day, to the hero in Pylai, grown victims not selected by the priest; the meat should be consumed at the spot (oủ $\kappa$ ó $\pi \circ \varphi \circ \rho \alpha$ ); a

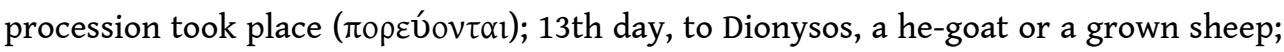
14th day, to Dionysos Sminthios, in the sanctuary of Herakles, a kid. 3) Artamitios: 20th day, to Hekate in Alenta, a sheep, a pig; to Zeus Horios, a he-sheep, grown ewes; to Apollo Horomedon, a kid; to Apollo Phyxios, a kid, an obeliskos, a goat; in the sanctuary of Herakles, to Apollo Phyxios, a kid; to Dionysos, in the sanctuary of Herakles, a kid; to Hermes, a yearling kid, grown goats; 25th day: to Zeus Soter, a grown victim; to Athena Soteira, a yearling, on the same altar; to Hekate, a pig. 4) Agrianios: 15th day, to the Hero in Pylai, a grown lamb, with procession, consumption at the spot; 22nd day: to the Hero in Amaxitos, the same offerings; 25th day: to the Hero in Nasiota, a lamb; 27th day: to the Hero in an anonymous place, an undetermined sacrifice. The calendar breaks with the beginning of Hyakinthios. The 'sacred law' of the tribe of the

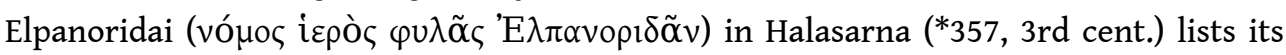
rituals. During meetings of the tribe a cult official (archeuon) offered a sacrifice of sheep; the information about the appointment of a priest is not preserved. The back side contains the proposal of a man concerning sacrifices $(\theta \varepsilon \omega \rho \tilde{\omega} v \tau \varepsilon \mu \varepsilon \dot{\varepsilon} \eta \mu \varepsilon \dot{\nu} v$

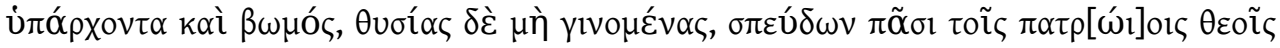

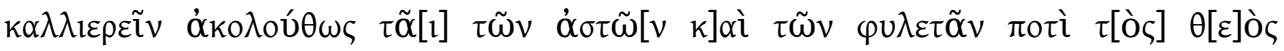

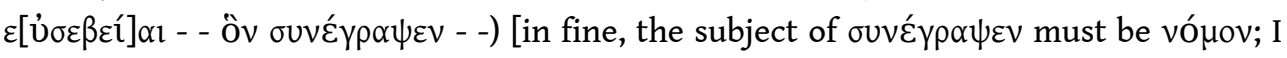
also use the lower case for $\pi \alpha \tau \rho \tilde{\omega} 101$ $\theta \varepsilon o$ í because this is not a divine name but a general reference to all the ancestral gods of the Elpanoridai: 'as he saw that there are precincts and altars but no sacrifices take place, eager to offer sacrifices to all the ancestral gods in accordance with the piety of the citizens and the members of the tribe 
- - he proposed a law']. The rest of the text is too fragmentary to make sense, but it is

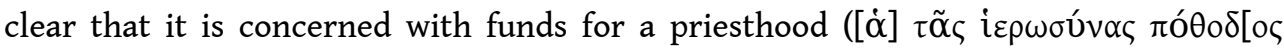

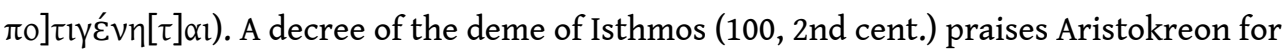
donating money to be used for sacrifices to the Theoi Patroioi. A two-day feast (ن்rodoxó) took place on 25 and 26 Hyakinthios; any violation of the terms of the endowment was punished with a fine of 1000 drachmai, payable to the Theoi Patroioi.

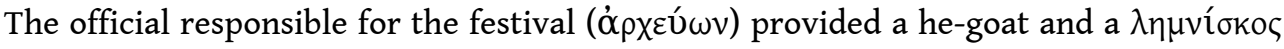
(wooven fillet) for the boys, who competed in a torch-race. The rest of the document (or another document pertaining to the same cult) is written on the back of the stele. In the fragmentary text one recognizes references to the funding of a sacrifice in the month Hyakinthios, to a panegyris, the election of epimenioi, activities on 9 Agrianios and in Artamitios, a fine of 1000 drachmas payable to the Theoi Patroioi, and financial stipulations. Cults: A large group of altars (397-423) evidences the variety of cults in Kos [we note the existence of many shared altars; for this phenomenon see EBGR 2010, 144]:

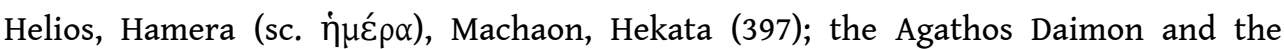
Agathe Tyche of a man and a woman (*398); Helios and Hamera (*399); Zeus Basileus (400); Hygieia (*401); Podaleirios (402); Aidos (403); Eileithyia (404); Zeus Patroios (405); Apollo, Asklepios, Herakles, the Dioskouroi, Helios, Hamera; Horai, Charites, Nymphs, Priapos, Pan, Hermaphroditos, Zeus Philios, Theoi Soteres, Hermes Probakchos, Peitho,

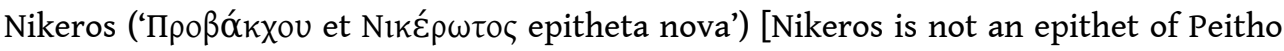
but (like Anteros) an aspect of Eros]; Zeus Nemeios, Poseidon Isthmios, Athena Nike, for

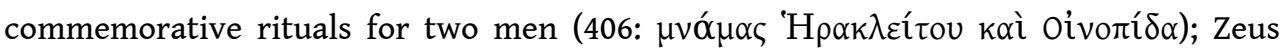
Soter and Athena Soteira (407); Poseidon Geraistios (408); Asklepios and Hygieia (409); (Zeus) Ourios (410); Zeus (411); Zeus Kataibates (412), Aphrodite Epekoos and Nike (413); Zeus Ktesios and Zeus Ourios (415); Zeus and Athena Lindia (416); Claudius Caesar Poseidon Asphaleios (417); Demeter, Plouton and Kore (418); Hadrian (419); Hygieia (420); Apollo Pythios (421); and Zeus Soter (422-423). Sanctuaries and sacred property: Many inscriptions refer to the erection of inscribed stelai in the sanctuaries of Apollo, Asklepios, Herakles, and near the altar of Dionysos, and in Kalymnos in the sanctuary of Apollo Dalios, but we do not list them for reasons of space. 14 new fragments can be added to the dossier of decrees and royal letters recognizing the asylia of the Asklepieion (207-245) but their authors cannot be determined $\left({ }^{*} 219,{ }^{*} 229,{ }^{*} 233-234\right.$, *236-245). Four fragments deal with sacred money $(73,96,361-363)$. A list from Halasarna contains the names of men and women who were allowed to participate in a deme's cult (104, 2nd cent.). A fragmentary text mentions the sanctuary of Apollo in Halasarna $\left({ }^{*} 111\right)$. An inscription records the dedication of land, gardens and buildings to the cult of the Twelve Gods and the hero Charmylos ( 355 , late 4 th cent.). One of the most interesting inscriptions is a dossier of documents concerning the arbitration of Kos in an internal conflict in Telos (132, ca. 300). Part of the conflict concerned i $\varepsilon \rho \alpha i$ $\delta$ íkal. The Koan arbitrators decided that the defendants in a lawsuit concerning the

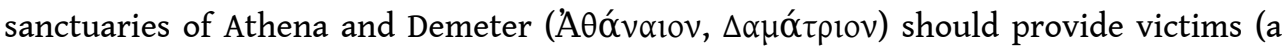
bull, a ram, an ewe) to the hekatomb that was to take place in the year of the monarchos Threagoras. Two defendants in public lawsuits were obliged to restore the altar of Asklepios. After a lacuna, the verdict continues with fines for violations of the verdict; fines by the treasurers and the hieropoloi were to be paid to Zeus Polieus and Athena Polias. The dossier concludes with an oath of the Telians, who obliged themselves to preserve the constitution and the amnesty. Festivals: Many texts refer to the announcement of honors during festivals (Pentaeteric or Megala Asklepieia, 
Dionysia, Rhomaia) but we do not list them for reasons of space. Foreign decrees found in Kos also mention this practice: in Erythrai honors were announced at the Dionysia and the Seleukeia (162, early 2nd cent.), in Bargylia in the agon for Artemis Kindyas (178). The decrees of Kos concerning the celebration for the defeat of the Gauls (68) and the recognition of the Leukophryena (90), the Nikephoria of Pergamon (251), and the Didymeia (153-154) were already known. A fragmentary decree $\left({ }^{*} 83,2\right.$ nd cent.) refers to a successful theoria sent to another city and the offering of sacrifices to a goddess with the epithet Boulaia [Hestia?], Zeus Boulaios, another god [Apollo?], and Artemis. A decree of the deme Antimacheia praises two hierotamiai for their successful efforts in increasing the funds available to the priest and the hieropoioi for sacrifices to the gods in accordance with the hiera diagrapha and for the annual feast (ن் demesmen; they also provided funds to the other demoteleis priests and priestesses (102, ca. 190 BCE). A decree, again of Antimacheia ( ${ }^{*} 105,2$ 2nd cent.), honors an individual for his services in the local cults; he conducted the sacrifices ( $(\dot{\varepsilon} \xi \dot{\varepsilon} \theta 0 \sigma \varepsilon)$ to Apollo and Demeter in accordance with a decree; he took care of the decoration of a sanctuary and

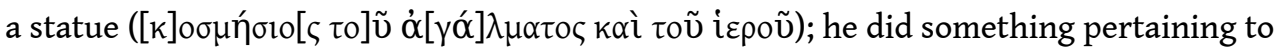
a pentaeteric celebration; he increased the funds of Apollo. Antimacheia also honored

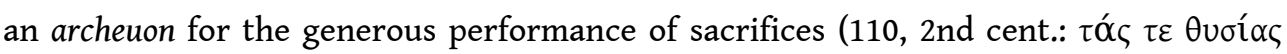

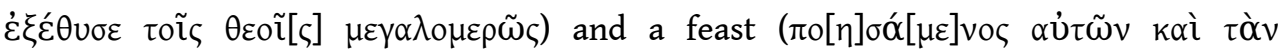

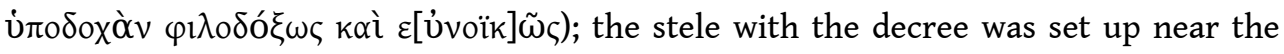

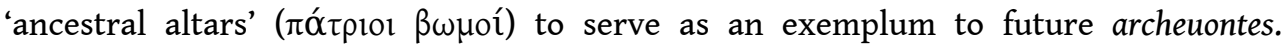
Halasarna honored a man who increased the deme's revenues, was appointed priest (of

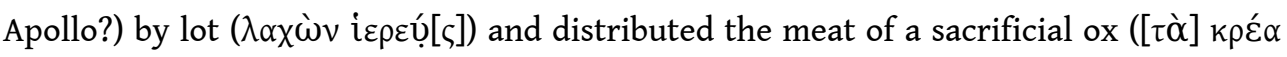

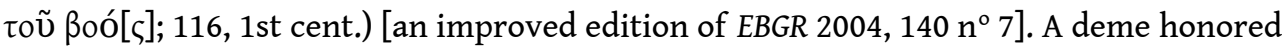
a man for his efforts for the performance of sacrifices according to the ancestral custom; the decree was set up in the sanctuary of the Theoi Patroioi (106, 2nd cent.). Rituals: An honorary decree for the doctor Philippos of Kos reports that he was sent by king Ptolemy III (?) to Kos together with other theoroi in order to bring a sacrifice to Asklepios and the other gods (31). A document concerning the restoration of the homopoliteia of Kos and Kalymnos details the procedure of the oath ceremony (152). Cult officials: Decrees of Halasarna were proposed by the napoiai $(109,117)$. Ruler cult: A very fragmentary letter by a Ptolemy (III?) mentions sacrifices, Arsinoe (II?), and a panegyris; it may be connected with a festival in Alexandria (249). A fragmentary regulation concerns the cult of Arsinoe (290). An honorific decree for Naxian judges mention a sacrifice offered to Ptolemy Soter (135, ca. $280 \mathrm{BCE}$ ). A fragmentary text (PH 8 $=61$, 2nd cent.) concerns the cult of a ruler, possibly Ptolemy V or VI; the decree refers to the dedication of an equestrian statue and of other images, it mentions a gilded

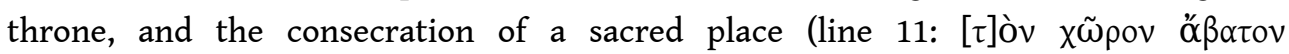
$\kappa \alpha \theta_{1 \varepsilon \rho} \tilde{\omega}\left[\sigma \alpha_{1}\right]$ ). A fragmentary decree (of the gerousia?) concerns the imperial cult $\left({ }^{*} 128\right.$, late 2 nd cent. CE); one recognizes a reference to an imperial image (line 8: घikóv[oc]). A small fragment provides instruction for the establishment of a festival ( $\dot{\alpha} \mu \varepsilon ́ \rho \alpha)$ for King Nikomedes I or II (344). Associations: There are two decrees of the Dionysiac artists $(120,124)$ and a letter of Sulla granting them privileges $(252)$. A decree

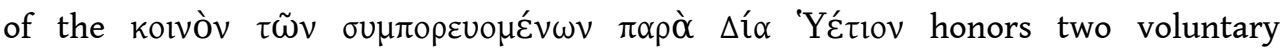
( $\alpha \dot{\tau} \tau \alpha \pi \alpha ́ \gamma \gamma \varepsilon \lambda \tau o l)$ epimenioi, who "conducted the sacrifices to Zeus and renewed the

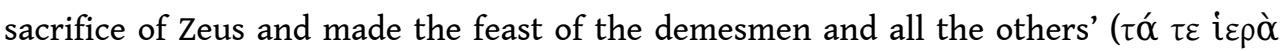

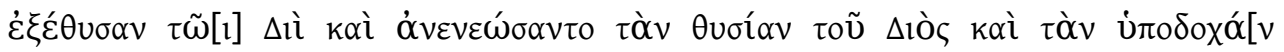




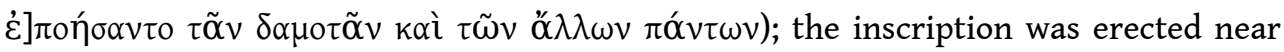
the altar of Zeus $(121$, ca. 200). A fragmentary decree of an association ( $\theta i ́ \alpha \sigma o \varsigma)$ invites those who wished to contribute to a sanctuary to make contributions for amounts of no less than 100 drachmas, $\left({ }^{*} 125\right)$. Foundations: The private endowments for cultic purposes include the well-known foundations of Diomedon (LSCG $177=348$ ), Pythion (LSCG $171=349$ ), and Pythokles (350), a foundation for a man's deceased child (351), an endowment concerning an exedra and a contest in memory of a man's son (353), and a similar endowment (354) as well as an endowment for the cult of Asklepios and the

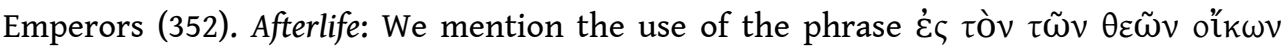
$\mu \varepsilon \tau \alpha \beta \alpha i v \omega$ (61 line 4, 2nd cent.) as a metonym of death. Varia: A decree concerning warships $(72,205 / 4 \mathrm{BCE})$, attests the practice of decorating their prows with divine

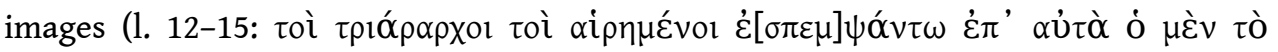

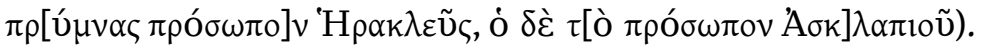

22) S. BRACKMANN, "Ein Votivtäfelchen mit einer ungewöhnlichen Weihinschrift für Zeus", ZPE 178 (2011), p. 221-222 [BE 2012, 77]: Ed. pr. of an inscribed bronze tablet in the form of a tabula ansata, probably from Asia Minor (Imperial period). The object has a dedicatory inscription addressed to Zeus Kraouandaseon in fulfilment of a vow [it seems to be the label for a dedication, not a dedication itself].

23) B. BRAVo, "Una tavoletta d'osso da Olbia Pontica della seconda metà del VI secolo a.C. (SEG XXXVI, 694): Apollo di Didyma e la nascità di Olbie polis", ZPE 176 (2011), p. 99119 [BE 2012, 309]: B. presents a very significant contribution to the better understanding of a puzzling text from Olbia (SEG XXXVI 694; IGDOP 93) which has been interpreted in the past as an oracle, a hymn, and a text connected with Orphism.

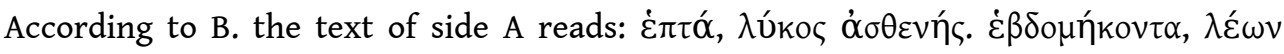

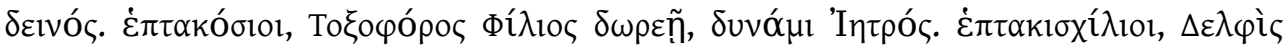

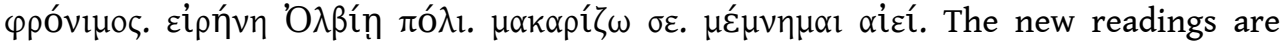

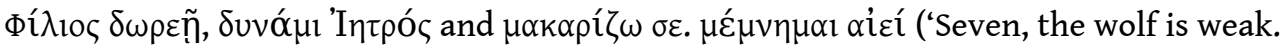
Seventy, the lion is terrible. Seven hundred, the archer is friendly through his gift, through his power he is a healer. Seven thousand, the dolphin is prudent. Peace for olbia. I regard you blessed. I always remember'). In B.'s interpretation, the tablet with the text belonged to a member of an association in Olbia devoted to Apollo's cult; it has nothing to do with Orphism. The text implies three individuals. He assigns the phrase

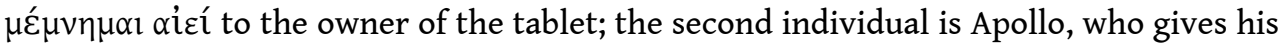
oracle ( $\dot{\varepsilon} \pi \tau \alpha$.... $\mu \alpha \kappa \alpha \rho i ́ \zeta \omega \sigma \varepsilon)$; the third individual is the recipient of the oracle, i.e. the Milesian founder of Olbia. The text reflects the various stages of Olbia's foundation and development, under the patronage of Apollo Lykeios, Apollo Ietros, and Apollo

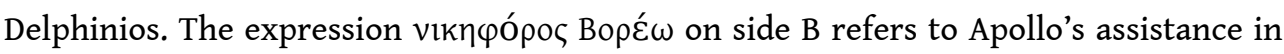
the defense of Olbia from Skythian attacks.

24) A. BRUGNONE, "Le sferette bronzee iscritte da Himera", Kernos 24 (2011), p. 77-94: Small bronze spheres found in the sanctuary at Piano in Himera (late 5th cent.) are sometimes inscribed with divine names. The word $\dot{\varepsilon} \imath \lambda \nu \sigma \alpha \mu \dot{\varepsilon} v \alpha \varsigma$ in an ineditum should be understood as an epithet of Eileithyia. The already published spherulae are inscribed with the names of Zeus Soter, Herakles, and Leukathea in the genitive. B. plausibly suggests that these objects were used in some form of divination (cleromancy).

25) H. BUjUKLIEV, M. KAMIŠEVA, "Novootrit Posvetitelen Nadpis ot Avgousta Trayana", Studia Classica Serdicensia 1 (2010), p. 409-413 [non vidimus; see N. SHARANKov, An.Ép. 2010, 
1458]: Ed. pr. of a dedication to Ares Saprenos غ̇ $\pi$ ńкoo in fulfillment of a vow (Augusta Traiana, 3rd cent. CE).

26) P. CABANES, "Le mécanisme d'Anticythère, les Naa de Dodone et le calendrier épirote", Tekmeria 10 (2011), p. 249-260: The inscriptions of the Antikythera mechanism, which became visible after its cleaning (see SEG LVI 392), provide important information for the Epirotan calendar and the agonistic festival of the Naia of Dodona. Since the Naia are mentioned along with the major contests of the periodos, the mechanism dates to the period between the promotion of the Naia to a crownawarding agon (ca. 192) and the Third Macedonian War (167 BCE). The agon took place in the second year of the Olympic pentatereris, i.e. in the year after the Olympic Games and immediately after the Nemea, which were celebrated in the early summer. The mention of the Naia together with the great panhellenic contests shows that the mechanism was created in a place near Dodona, probably in one of the Corinthian colonies, perhaps by a scholar from the school of Archimedes. The month names that appear on the mechanism cannot yet be attributed to a specific city; but they certainly belong to the calendar of a Corinthian colony in Epirus or its vicinity. The month names on the mechanism (Artemisios, Psydreus, Gamelios, Agrianios, Panamos, Apellaios, Phoinikaios, Kraneios, Lanotropios?, Machaneus, Dodekateus, Eukleios) have great similarity with the months attested in south Illyria and Epirus. The place of Dodekateus between Machaneus and Eukleios shows that Dodekateus was not an intercalary month but the 11th month of the year. As regards the month that had been read as

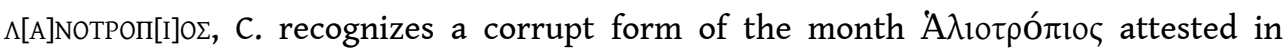

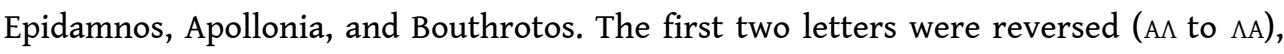

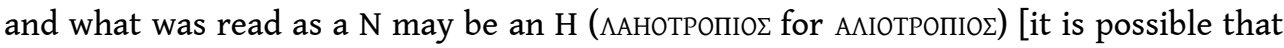

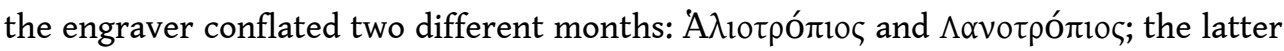
is attested in Tauromenion (see supra ${ }^{\circ} 13$ )]. The month $\Delta$ ?????? (cf. theatúıৎ (cf. the Macedonian Daisios?), attested in Dodona in the early 4 th cent. and possibly connected with the cult of Dionysos, no longer existed at the time of the mechanism, probably because it had been replaced by Agrianios. C. suggests the following correspondences between the months in the mechanism and the months of the Epirotan year, which started in February/March (in case of divergences, the name in a parenthesis is the one attested in Epirotan inscriptions): 1) Artemisios; 2) Psydreus; 3) Gamelios; 4) Agrianios; 5) Panamos (Phoinikaios); 6) Apellaios (Haliotropios); 7) Phoinikaios (Kraneios); 8) Kraneios (Panamos); 9) Lanotropios (Apellaios); 10) Machaneus; 11) Dodekateus/ Deudekateus; 12) Eukleios. [This result is not convincing because too many months with the same name appear in different sequence in the two calendars. Since the mechanism is the product of technical sophistication and astronomical research, its sequence of months must be trusted. For this reason, the arguments used by Cabanes in the past to determine the sequence of the months in the Corinthian/Epirotan calendar (see EBGR 200 , 37) should be revisited. It is noteworthy that C. TRÜMPY, Untersuchungen zu den altgriechischen Monatsnamen und Monatsfolgen, Heidelberg, 1997, p. 163, has proposed a radically different month-sequence (p. 155-164). See supra $\mathrm{n}^{\circ} 13$ ].

27) F. CAMIA, "Lykos, Son of Hermolaos, hiereus heptaeterikos of the Sebastoi. Emperor Worship and Traditional Cults at Thessalian Hypata (SEG 54, 556)", ZPE 179 (2011), p. 145-154 [BE 2012, 254]: An inscription from Hypata (SEG LIV 556; EBGR 2003, 188)

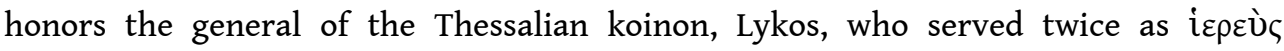

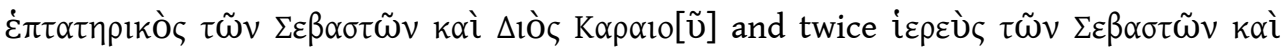




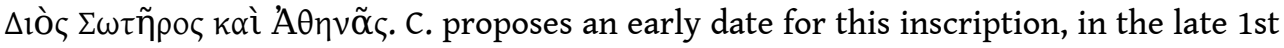

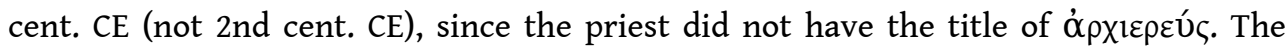
designation of the priest as $\dot{\varepsilon} \pi \tau \alpha \tau \eta \rho \kappa o ́($ indicates that he served during the celebration

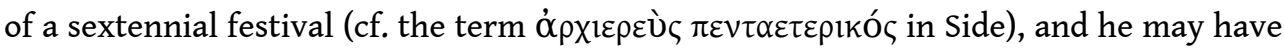
stayed in office for the entire period of the heptaeteris (i.e. a total of 12 years). This sextennial festival of the imperial cult, celebrated in connection with the cult of Zeus Karaios, was different from the annual festival of the imperial cult (Sebasta); it may have had the character of a festival of the Thessalian Koinon. The designation of Lykos' priesthoods show that the imperial cult was connected with traditional cults in Hypata, the cult of Zeus Karaios and the cults of Zeus Soter and Athena.

28) F. CAMIA, "Spending on the agones. The Financing of Festivals in Roman Greece", Tyche 26 (2011), p. 41-76 [BE 2012, 132]: C. gives an overview of the types of festivals in Roman Greece, the expenses connected with them, and the various ways through which the expenses were covered (public spending, agonistic foundation, private funding, donations of benefactors).

29) F. CAMIA, Theoi Sebastoi: il culto degli imperatori romani in Grecia (Provincia Achaia) nel secondo secolo D.C., Athens/Paris, 2011: C. studies the cult of the emperors of the Antonine dynasty in Greece, which is primarily attested through inscriptions. He collects the evidence for the cult of Trajan in Athens and Hermione (as Zeus Embaterios); of Hadrian in Athens, Eleusis (Theos Panhellenios), and other places of Achaea; of Sabina (as neotera Theos?, i.e. Demeter or Kore); of Antoninus Pius in Athens and Sparta; and of Marcus Aurelius, Lucius Verus, and Commodus (p. 25-83). The cultic activities and celebrations in connection with the imperial cult followed the model of the traditional civic festivals and included sacrifices, processions, and contests. C. discusses the evidence for contests dedicated to the emperor in Athens and the Peloponnese, and especially the ephebic contests in Athens in connection with the imperial cult (Hadrianeia, Antoneia, Philadelpheia, Kommodeia; p. 85-131). Finally, C. discusses the high priests of the imperial cult in the cities and the Achaian, Boiotian, and Thessalian koina (p.133-188), the association of the emperors with traditional cults and cult places (p. 189-228), and the imperial cult in the koina of Greece (p. 229242; on 236-242, discussion of the thorny issue of whether the archiereus of the Hellenes/helladarches can be considered as a provincial high priest). In a series of tables, C. collects the epigraphic evidence for dedications to emperors and members of the imperial family (p. 249-269), divine and honorific epithets of emperors (Trajan: Theos, Zeus Embaterios; Hadrianos: Archegetes, Boulaios, Neos Dionysos, Neos Pythios, Olympios, Theos, Zeus Eleutherios; Antoninus Pius: Theios, Zeus Eleutherios and Olympios; p. 270-274), agonistic festivals for emperors (Athens: Sebasta, Hadrianeia, Olympia, Panhellenia, Germanikeia, Antoneia, Philadelpheia, Epinikia, Kommodeia, Kaisareia; Corinth: Kaisareia/Isthmia; Sikyon: Kaisareia; Epidauros: Kaisareia/ Asklepieia; Argos: Sebasteia/Nemea; Sparta: Kaisareia, Olympia Kommodeia; Lykosoura: Kaisareia/Lykaia; Akraiphia: Megala Ptoa Kaisareia; Thespiai: Sebasteia Mouseia, Kaisareia Erotideia Rhomaia; Thebes: Kommodeia Dionysia Herakleia; Hyampolis: Megala Kaisareia; Kaisareia in Gythion, Messene, Patrai, Lebadeia, Tanagra, and Chalkis; Sebasteia in Hypata, Echinos, and Demetrias; p. 274-278), municipal high priests (p. 278-282), and high priests of the Achaian, Boiotian, and Thessalian Koinon (p. 282283). 
206 30) E. CERBO, "Il peana eritreo: layout e versificazione", in Epigrammata - Susini, p. 221249: C. discusses the metrical structure and epigraphic layout of a hymn to Asklepios, which is preserved in four copies, in Athens, Dion, Eryrhrai, and Ptolemais (FURLEYBREMER, Greek Hymns II p.160). She observes that dactylic and iambic verses were combined; the poem continues the tradition of cultic songs; in the performance, the soloist and the chorus alternated; the layout on the stone is connected with the poem's structure; one observes a development from a monostrophic structure (repetition of the same strophe three times) to the sequence of three similar but not identical strophes.

31) C. ChAndezon, "Particularités du culte isiaque dans la basse vallée du Céphise (Béotie et Phocide)", in Philologos Dionysios, p. 149-182 [BE 2013, 211]: C. examines the votive reliefs related with the cult of the Egyptian gods from Boiotia and Phokis. The reliefs on an altar with manumission records of slaves dedicated to Sarapis and Isis in Orchomenos (IG VII 3200-3204)and an inscribed altar from Chaironeia (IG VII 3308) attest the sacrifice of deer in the cult of the Egyptian gods; this practice also existed in the sanctuary of Isis in Tithorea (Pausanias 10.32.13). Literary sources and archaeological evidence from Kalapodi suggest that this practice may have been influenced by the cult of Artemis. C. collects further evidence for this type of sacrifice in the Hellenistic and Imperial period.

32) A. CHANiotis, "Phaistos Sybritas. An Unpublished Inscription from the Idaean Cave and Personal Names Deriving from Ethnics", in Onomatologos, p. 15-21 [BE 2011, 484]: Ed. pr. of a dedicatory inscription engraved on a cauldron from the Idaean Cave (ca. 550-

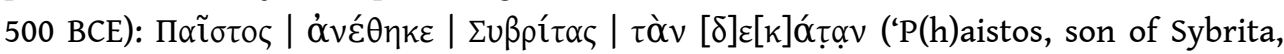
dedicated this tithe'). The dedication was made by Phaistos, son of Sybrita, as a tithe (from war booty? from agricultural produce or trade?). Both Phaistos' name and that of his mother reflect connections with cities around Mt. Ida, not far from the sanctuary, where he brought his dedication.

33) A. CHANIOTIS, “'The Best of Homer': Homeric Texts, Performances, and Images in the Hellenistic World and Beyond. The Contribution of Inscriptions", in E. WALTER-KARYDI (ed.), Homer: Myths, Texts, Images: Homeric Epics and Ancient Greek Art. Proceedings of the 11th International Symposium on the Odyssey, Ithaca, September 15-19, 2009, Ithaca 2010, p. 257-278: In the Hellenistic and Imperial periods we may observe a trend towards a fragmentation of Homeric poetry: the separate performance of parts of the epic poems, the perception of sequences of verses as epigrams, mythological compilations, the use of selected passages in education, presentation of Homeric scenes by pantomimes, the selection of individual hexameters and their use as answers to oracular enquiries (Homeromanteion) [on the Homeromanteion see also A. KARANIKA, "Homer the Prophet: Homeric Verses and Divination in the Homeromanteion", in Sacred Words, p. 255-277], and the use of Homeric verses as proverbial sayings. Since Homer's poetry was in a sense the voice of the Muses, it could easily be elevated above the status of 'normal', mortal poetry. Zosimos, a worshipper of Theos Hypsistos in Phrygia, declared in an epigram that he "wrote whatever the mortals need on a folded tablet with spiritual writings and Homeric verses, predicting the future for the wise" (SEG XLIII 945, 3rd cent. CE). Zosimos' text was not a collection of gnomic wisdom, but a collection of Homeric verses used as oracular responses. Performances by rhapsodes and their participation in agonistic festivals continued in the Hellenistic period, although they 
were not as popular as other forms of entertainment, competition, and spectacle [see also EBGR 2010, 2006].

210 34) A. Chaniotis, "Dynamic of Emotions and Dynamic of Rituals. Do Emotions Change Ritual Norms?", in C. BRosius, U. HÜSKEN (eds.), Ritual Matters: Dynamic Dimensions in Practice, London, 2010, p. 208-233: Rituals are emotionally loaded occasions, in which the spontaneity of emotions may collide with the normative power of rituals. As rituals may intensify pre-existing tensions, it occasionally occurred that festivals and other celebrations were disturbed by violent events. A study of cult regulations shows that the close observation of emotional responses to rituals was one of the factors that led to the modification of pre-existing rituals or even to the creation of new ones. Ritual practices ( $\varepsilon \dot{\mathbf{U}} \varphi \eta \mu i ́ \alpha$, acclamations, abstinence from food and sex, etc.) aimed at creating the proper emotional frame for a celebration (e.g. LSAM 81) but also at manipulating the emotions of gods and other supernatural powers (prayers, magical prayers). Some of the measures in cult regulations, such as prohibitions against the wearing of seethrough clothes, expensive jewelry, and weapons, measures for order and against drunkenness, rules concerning the arrangement of processions, or prohibitions against the presence of traitors in sanctuaries or the participation of an adulteress in a mystery cult, diminished the danger of tensions caused by envy, anger, hatred, pride and other emotions (e.g. LSAM 6, 20, 58, 61; LSCG 51, 59, 60,65, 83, 94, 124, 173; E. LUPU, Greek Sacred Law. A Collection of New Documents, Leiden, 2005, $\mathrm{n}^{\text {os }} 5,14$ and 22). Emotional excesses in funerals were one of the reasons for the introduction of strict limitations concerning funerary rituals (e.g. LSCG 77; LSAM 16; LSCG Suppl. 64). The emotional response to the death of benefactors or prominent citizens introduced a new ritual: the population seized the corpse and transformed the private funeral into a public event (I.Knidos 71) [see EBGR 2006, 26; 2007, 30 bis]. The experience of extreme violence during civil war led to the introduction of elaborate rituals for the establishment of concord (e.g. measures after the civil war in Nakone: Lupu, ibid. $\mathrm{n}^{\circ} 26$ ) [on this subject see now A. CHANIOTIS, "Normen stärker als Emotionen? Der kulturhistorische Kontext der griechischen Amnestie", in K. HARTER-UIBOPUU, F. MITTHOF (eds.), Vergeben und Vergessen? Amnestie in der Antike. Akten des ersten Wiener Kolloquiums zur Antiken Rechtsgeschichte, Wien, 27.-28.10.2008, Vienna, 2013, p. 47-70]. New rituals were also introduced in order to display the gratitude of a city towards a benefactor (new rituals in Teos for Antiochos III and Laodike: SEG XLI 1003; EBGR 2007, 31].

211 35) A. Chaniotis, "Festivals and Contests in the Greek World", in Thesaurus Cultus et Rituum Antiquorum VII, Los Angeles, 2011, p. 1-43 and 160-172: This general introduction to the main features of Greek festivals (definition, general characteristics, program, funding, officials, order, preparation, socio-political aspects, historical development, dynamics) draws primarily on the epigraphic evidence. Five festivals are summarized as case studies: Thesmophoria, Hyakinthia, Daidala, the festival of the Great Gods in Andania (LSCG Suppl. 65), and the Demostheneia of Oinoanda (SEG XXXVIII 1462).

212 36) A. CHANIOTIs, "Emotional Community through Ritual. Initiates, Citizens, and Pilgrims as Emotional Communities in the Greek World", in Ritual Dynamics in the Ancient Mediterranean, p. 264-290: Emotions were an inherent feature of every Greek festival, and various media were applied to arouse the desired emotions in and among the participants. This study is devoted to a specific kind of emotionality which can best be observed in the Hellenistic and Imperial periods: the conscious arousal of emotions that 
aimed to construct a close relationship between the cult community and the divinity. "These emotions shaped the cult community as an "emotional community", that is, a community of people who were expected to feel the same emotions (hope, fear, anger, affection, pride, etc.) in the worship of a deity.' Cult communities were 'emotional communities' in more than one sense: the emotions of hope and fear dominated their relation to gods; emotions were excited by rituals; communication with divine powers had an emotional background; and specific emotions were connected with the cult of particular gods. Selected case studies illuminate these aspects: the measures taken by a Roman magistrate in order to create the proper emotional atmosphere for the celebration of a victory of Caius Caesar in Messene (SEG XXIII 206, 2 CE); the establishment of emotional community through the shared emotional experience of initiation (cf. Apuleius, Metamorphoses 11; Firmicus Maternus, De errore profanarum religionum 23.5; the Isis praise from Maeoneia: I.Thrac.Aeg E205; P.Oxy. XI.1382; Lucian, Alexander 38); the creation of a bond of affection between the Ephesians and their Artemis in the Imperial period (LSAM 31 = I.Ephesos 24; I.Ephesos 27 A lines 12f.; SEG XLIII 756; cf. the attribute philartemis); and the emotional interaction among the worshippers of the Mother of the Gods at Leukopetra during her festival (I.Leukopetra 3, 35, 39, 47, 53, $63,65,69,78,90,153)$ and among the pilgrims to the Asklepieion in Rome (IGUR I 148; cf. Aelius Aristides, Hieroi Logoi 2.21). The means through which the construction of an emotional community was enhanced included priestly proclamations (e.g. LSCG Suppl. 91), acclamations (cf. EBGR 2010, 37), and the publications of textual and visual narratives of miracles (e.g. SEG XLIII 435; LIII 1344; LVII 1186; cf. SEG XXX 1480). The impact of inscriptions increased when they were embedded in rituals, esp. in oath rituals (e.g. TAM V.3.1539). The creation of such emotional communities did not apply to all cults and religious practices but characterized cults with soteriological aspects (mystery cults), civic cults that forged identity, and cults that were based on the personal experience of the worshippers with divine power. Originally limited to mystery cults, in the Imperial period this kind of emotionally-loaded faith characterizes cult communities beyond the exclusive circles of the initiates and the devotees of monotheistic religions. The worshippers of the 'Highest God' (Theos Hypsistos) were known by a name that unequivocally designated them as an emotional community: thesosebeis, 'those who fear god'.

37) A. CHARAMI, "Fêtes et concours au gymnase de Tanagra", CRAI (2011), p. 853-873 [SEG

LIX 492]: C. publishes a stele from Delion (territory of Tanagra) inscribed with the names of ephebes and officials of the gymnasium (ca. 222-235 CE). Two similar inscriptions in the Museum of Chalkis (IG XII Suppl. 646; OMS II 1275-1281) and in the Museum of Thebes (IG VII 2450; OMS II 1390-1393) must be pierres errantes from Tanagra. The list, inscribed upon the initiative of the gymnasiarchos and kosmetes, contains the names of ephebes, probably belonging to two or three age classes (ca. 18-20 years); they were divided into two sections (tagmata), each under an ephebe who served as a tagmatarches. The gymnasiarchos reports that he had provided olive oil in the month

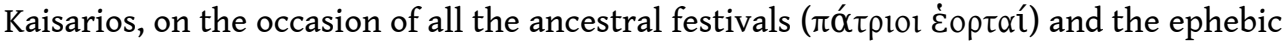

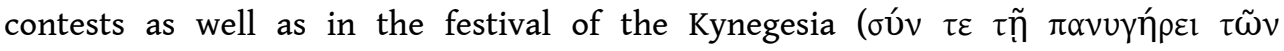

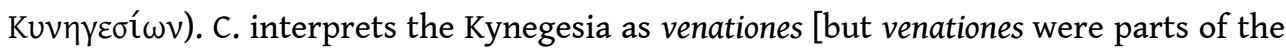
celebration of the imperial cult and not independent events that can be characterized as a panegyris; perhaps this festival was connected with the cult of a hunter-deity, e.g. Artemis, Herakles, or Orion (see below)]. Ephebes also occupied offices connected with religious and agonistic activities (the priest of the imperial cult, the priest of the 
ephebes, the $\dot{\varepsilon} \sigma \tau 1 \alpha$ $\tau \omega \rho$, i.e. supervisor of the banquets, and the agonothetai). The new text provides important information for the religious and agonistic life in Tanagra. 13 agonothetai, recruited from among the ephebes were responsible for eight agones. There were three agonothetai for the Delia, which must have been the most important contest [perhaps with events on three days, with one agonothetes responsible for each day]; the son of the gymnasiarchos served among the agonothetai for this contest. There were two agonothetai for three contests: on the birthday of the emperor, for the enigmatic Hekatephoria, and for the boarsion, i.e. the carrying of an ox for a certain distance, a contest attested in Athens and Rhodes (IG XII.1.102). The agon $\pi \varepsilon p i ̀ ~ \alpha \dot{~} \lambda \kappa \tilde{\eta} \varsigma$, which was probably connected with the cult of Herakles, the Hermaia, the military contest $\pi \rho \circ \sigma \delta \rho \mu \alpha i$, and the enigmatic $\delta i ́ \xi \varepsilon \sigma \tau о \varsigma$ were under the responsibility of one agonothetes each. The new inscription does not mentions three contests mentioned in

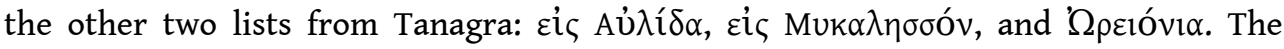
agonistic culture in Tanagra shows a certain prosperity in this period and the effort of the citizens to preserve a local identity. Some of the ephebic festivals celebrated in Tanagra are also attested for Athens; it seems that the ephebic institutions of Tanagra followed the Athenian model. D. KNOEPFLER, ibid., p. 867-871, comments on the importance of the new find. He suspects that the omission of two 'lieux de mémoire', Aulis and Mykalessos, is due to the fact that the ephebes did not visit these sites every year. The festival $\Omega \rho \varepsilon ı$ óvi $\alpha$, perhaps the contest for the hero-hunter Orion, was

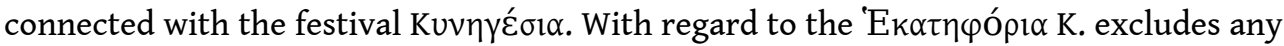
connection with Hekate and suspects that the name of the festival derives from the

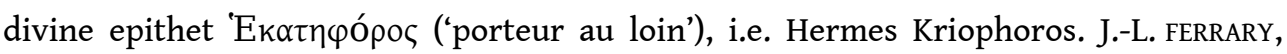
ibid., p. 871-873, observes that the emperor mentioned in line 17 may be Severus Alexander or Gordian III. The month Kaıoópios (line 58) must have been the first month of the year, as in Asia, and this explains why the gymnasiarch offered olive oil during this month. The introduction of this month in Tanagra must be attributed to a decision of the city. The mention of 13 agonothetai explains why in an inscription from Klaros, commemorating a delegation from Kyme $(144 \mathrm{CE})$, four or five of the six members of the chorus are designated as $\dot{\alpha} \gamma \omega v 0 \theta \varepsilon$ z $\alpha \mathrm{l}$ : the chorus consisted of the scions of élite families.

214 38) K. Clinton, N. Dimitrova, "Maroneia Honors Q. Lutatius Catulus in Samothrace", in O. PALAGIA, B.D. WEscoAT (eds.), Samothracian Connections. Essays in Honor of James R. McCredie, Oxford, 2010, p. 185-192: Ed. pr. of a dedication from the sanctuary of the Great Gods in Samothrace (ca. 80 BCE). The city of Maroneia dedicated a statue of Q. Lutatius Catulus (the consul of $78 \mathrm{BCE}$ ) to the Theoi Megaloi, probably for services rendered during the Mithridatic War.

39) K.M. COLEMAN, "Exchanging Gladiators for an Aqueduct at Aphrodisias (SEG 50.1096)", Acta Classica 51 (2008), p. 31-46: In a recently published letter of Hadrian from Aphrodisias (SEG L 1096; EBGR 2001, 152), the emperor asks the city to reconsider the claim of some citizens that they were unable to carry the financial burden of the high priesthood and approves of the proposal to allow high priests to make cash payments toward the construction of an aqueduct instead of organizing gladiatorial contests. C. argues that this proposal originated in nominees for this priesthood, who were reluctant to assume the traditional liturgy of sponsoring gladiatorial games because of its high cost. 
216 40) O. COLORU, “Old and New Magical Inscriptions", ZPE 176 (2011), p. 135-138: C. presents a new edition of a defixio allegedly from the necropolis of Olbia, now in a private collection (ca. 350-300 BCE; SEG L 702; EBGR 2001, 175). The text consists of 8 names. C. recognizes remains of magical signs on the lead tablet. He also presents the ed. pr. of an amulet in the form of a prism (5th cent. CE). The four sides have a representation of Anoubis with staff or kerykeion and the name I $\alpha \omega$ (A), the number 19 ( $1 \theta$ ) followed by the name $P \alpha \theta \alpha v \varepsilon \eta \lambda$, and a sequence of vowels (B-C), and an invocation

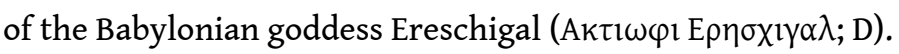

41) N. CORfù, R. WACHTER, "Eine böotische Scherbe mit Graffito", ZPE 179 (2011), p. 141144: Ed. pr. of an inscribed fragment of a Boiotian kantharos (ca. 450-400 BCE), now in the Collection of the University of Basel. The graffito on the vase is a dedication to Apollo ( $\tau$ ' $\pi \dot{\varepsilon} \lambda o y[1])$. The vase's provenance is either Thebes or, more probably, the sanctuary of Apollo Ptoios in Akraiphia.

218 42) E. CSAPO, P. WILSON, "Le passage de la chorégie à l'agonothésie à Athènes à la fin du IV ${ }^{\mathrm{e}}$ siècle", in L'argent dans les concours, p. 83-105 [BE 2011, 240]: The last attestation of choregoi in Athensdates to $319 \mathrm{BCE}$, the first attestation of agonothetai to 306; consequently, the abolishment of the choregia is usually attributed to Demetrios of Phaleron. An inscription from Acharnai (SEG XLIII 26B), which honors an epimeletes in charge of the Dionysia in $315 \mathrm{BCE}$, has been regarded as evidence for the abolishment of choregia early in Demetrios' rule. The authors argue that the presence of an epimeletes in the deme does not prove the existence of an agonothetes in the city already at that time; Menander's Samia implies the existence of choregia until the time of the work's composition (ca. 315-309); choregoi are attested in Aixone until 313 BCE (SEG XXXVI 186) [but C. FEYEL, BE 2011, 240, points out that this date has been moved to 340/39 by D. Ackermann in an unpublished study]; the agonothesia for the Panathenaic festival cannot have started earlier than $310 \mathrm{BCE}$. They argue that the inscription from Acharnai attests procedures used in a period of transition from the one system to the other. They also assign to this process of transition an honorific decree for Nikostratos for his contribution to the Dionysia (IG II ${ }^{2} 551$ = SEG XXIV 109, 318/7 BCE). They argue that the $\dot{\varepsilon} \pi \mu \varepsilon^{\prime} \lambda \varepsilon 1 \alpha$ exercised by Nikostratos covered the music contests of the Dionysia. 'Le décret nous apprend qu'il détient une épiméleia, laquelle inclut des relations avec des chorèges' (p. 95). They assume that Nikostratos was appointed as special epimeletes for the Dionysia earlier than $318 \mathrm{BCE}$, when the regime of Demetrios tested the model of a single administrator of the contests. In this interpretation, the choregia continued

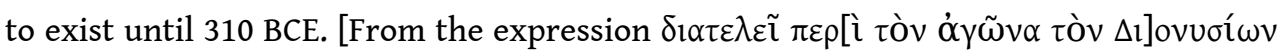

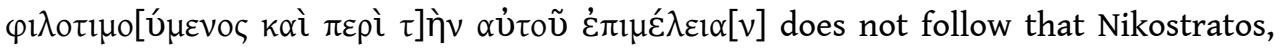
who was not a citizen, had an $\dot{\pi} \pi \mu \varepsilon \dot{\varepsilon} \lambda \varepsilon 1 \alpha$, a 'responsabilité exercée à titre officiel'. He only offered services pertaining to the $\dot{\varepsilon} \pi \mu \varepsilon \dot{\varepsilon} \lambda \varepsilon 1 \alpha$. Cf. C. FEYEL, BE 2011, 240, who also observes that the date ( $318 \mathrm{BCE})$ is not certain]. The authors collect evidence for the part played by foreigners in the funding and administration of the Athenian theater in the second half of the 4 th cent.

219 43) A. DALE, A. ELlis-EVANS, “A Cypriot Curser at Mytilene”, ZPE 179 (2011), p. 189-198: The authors republish three defixiones from Mytilene (4th/3rd cent.; SEG XLVIII 10551057; EBGR 1998, 136). On the basis of linguistic features, they argue that they were written by a Cypriot with a period of residence among Aeolic speakers. The context may be a legal conflict or problems connected with the integration of an immigrant in a foreign place. 
44) G. Deligiannakis, "Late Paganism on the Aegean Islands and Processes of Christianisation", in Late Antique Paganism, p. 311-345: D examines the latest evidence for pagan worship in the provincia Insularum (3rd-6th cent.). Although there is a decline in inscriptions displaying piety towards the traditional gods after ca. $260 \mathrm{CE}$, the physical condition of temples deteriorated, and blood sacrifice was dramatically restricted, there are indications of continuing cult activity. In the sanctuary of Athena Lindia, a podium temple near the north corner of Athena's temple may be identified with either the temple of Psithyros (I.Lindos 484) or that of the imperial cult; during the 3rd cent. CE members of elite families supported the cults and assumed priesthoods; there are also purity regulations that give emphasis to the purity of the mind (LSCG Suppl. 91, 139) and, around $300 \mathrm{CE}$, elaborate dedicatory epigrams by the priest Aglochartos mention the renewal of the sacred olive grove (I.Lindos 496, 498; IG XII. 1.779). Statues of Athena Lindia decorated the senate in Constantinople and the collection of Lausus, chamberlain to Theodosius II; their removal may be connected with the closure of the cult (late 4th cent. CE?). The Heraion of Samos is the best documented late Antique sanctuary. The evidence includes epigrams dedicated to Hera that mention repairs of the temple and the pilgrimage of a governor to the Idaean Cave (IG XII.6.584 and 610); governors were honored through dedication in the sanctuary (IG XII.6.585, 605-607); Julian's accession was hailed with enthusiasm (IG XII.6.427). A statue of Hera was transferred to Lausus' collection in the late 4th cent.; the temple was converted to a Christian basilica after ca. 450 CE. In Patmos, the cult of Artemis was supported by the priestess Vera (SEG XXXIX 855, 4th/5th cent. CE?), who performed the traditional sacrifice of a pregnant she-goat, possibly in defiance of anti-pagan legislation. Archaeological evidence from the sanctuary of Apollo and Herakles in Halasarna on Kos indicates pagan activity after the destruction of the temple. In connection with temple conversion, D. adduces an inscribed oracle of Apollo that predicts the conversion of a temple into a church of Mary (IG XII.6.1265) and archaeological evidence from Naxos (temple-church at Gyroula) and Kalymnos (conversion of the temple of Apollo Dalios). There is no evidence for systematic Christian iconoclasm.

45) A. DELLI PIZZI, "Impiety in Epigraphic Evidence", Kernos 24 (2011), p. 59-76: Impiety ( $\dot{\alpha} \sigma \varepsilon \varepsilon \beta 1 \alpha)$ is mentioned in two types of inscriptions: in legal texts in which the violation

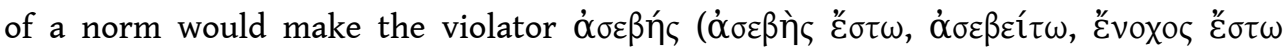

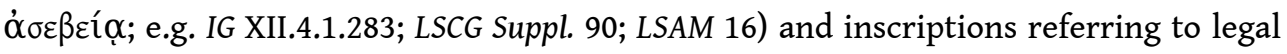
prosecution of individuals for impiety, usually for serious offences (IG I ${ }^{3} 426$; IG II ${ }^{2} 1635$; I.Ephesos 2). The formula ó $\sigma \varepsilon \beta \grave{\eta} \varsigma$ ह̌ $\sigma \tau \omega$ should be considered as a deterrent, informing a violator that in the future he might face the consequences (divine punishment, exclusion from a cult).

46) F. DEMIRKÖK, "Four Inscriptions Discovered in the Marmaray Excavations", in U. KосABAş (ed.), Istanbul Archaeological Museums. Proceedings of the 1st Symposium on Marmaray-Metro Salvage Excavations, 5th-6th May 2008,Istanbul, 2010, p. 161-174: Ed. pr. of a very interesting dedication (late 1st cent.) found during the construction of the Istanbul subway. It is a statuette representing Kybele on her throne, flanked by two lions and with a lion on her lap. A dedicatory inscription is on the base. C. Lollius Cato

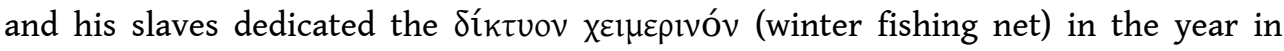
which Poseidon held the eponymous magistracy of basileus (probably in Byzantion); the name of the recipient of the dedication was written on the missing part of the base 
(Poseidon?). This dedication is paralleled by the dedication of a Hellenistic stele with a representation of Kybele to Poseidon and Aphrodite Pontia by fishermen and farmers in Kyzikos. Another Hellenistic votive stele from Parion mentions a diktyarches (the man in charge of the nets; L. ROBERT, "Inscriptions de l'Hellespont et de la Propontide", Hellenica IX, Paris, 1950, p. 81, 94-97). The dedication's background is a fishing practice in the Bosporus: the use of fixed nets in order to catch migrant fish. The winter fishtraps were dedicated at the end of the season. D. also presents two fragmentary lead tablets (p. 169: 'curse tablets'; 4th/5th cent.). On one of them D. recognizes a palindrome and the drawing of a woman rising from a ship, with her arms raised like the claws of a crab; on the reverse, there is the drawing of a demon with animal head and human body, surrounded by magical words 'thought to be astrological'. Images (a naked figure, two tables), palindromes, and magical words are also engraved on the second tablet. [As one sees in the drawing, the palindrome $\alpha \beta \lambda \alpha v \alpha \theta \alpha v \alpha \lambda \beta \alpha$ (twice) and the magical word $\alpha \kappa \rho \alpha \mu \mu \alpha \chi \alpha \mu \alpha \rho$ are repeated, each time with the last letter omitted, so that the three inscriptions have the form of triangles. The word $\varepsilon v \lambda \alpha \mu \omega t$ is repeated in the same manner under one of the tables; it is found both on curses (e.g. SEG LVII

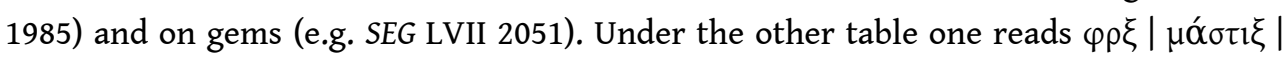
$\imath \alpha \beta \alpha \mid \sigma \beta \cup \theta$. One also recognizes the magical sign, which appears on gems in connection with Chnoubis and Solomon (e.g, EBGR 2000, 215; 2008, 28). D. reports that also $\mu \alpha \rho \mu \alpha \rho \alpha \omega \theta$ and $\alpha \beta \rho \alpha \sigma \alpha \xi$ are written on the tablet, but they are not in the drawing. A more detailed study of these objects will probably reveal more].

47) J.H.F. DIJKSTRA, "The Fate of the Temples in Late Antique Egypt", in Late Antique Paganism, p. 389-436: The archaeological, epigraphic, and papyrological evidence for the decline of temples in Late Antique Egypt does not confirm the stories of violent temple destruction narrated by Christian literary sources. Temples were more often used as "quarries" than converted into Christian churches. A weakening of their financial foundation was often responsible for their decline. Regional studies are necessary for a differentiated and reliable picture.

48) N. Dimitrova, K. Clinton, “A New Bilingual Votive Monument with a 'Thracian rider' Relief”, in Studies Tracy, p. 55-61: Ed. pr. of a votive relief with the Thracian Rider God, now in a private collection, probably from Thrace (Imperial period). A bilingual inscription records that the dedication was made by a slave in fulfilment of a vow

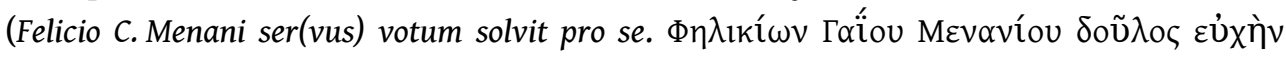

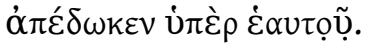

49) T. DREW-BEAR, A. IVANTCHIK, "Honneurs à Apamée pour Proclus Manneius Ruso", in L. SUMMERER, A. IVANTCHIK, A. VON KIENLIN (eds.), Kelenai - Apameia Kibotos. Développement urbain dans le contexte anatolien, Bordeaux, 2011, p. 281-293 [BE 2012, 409]: Ed. pr. of three inscribed bases of statues for Proclus Manneius Ruso, a benefactor of Apameia (late 2nd cent. CE); a fourth base was already known (IGR IV 791). The four statues of Ruso had been erected in different locations within the city. The inscription lists his services, one of which is of interest with regard to the imperial cult. Ruso was sent as envoy to the emperors (probably during the reign of Marcus Aurelius) 'and succeeded

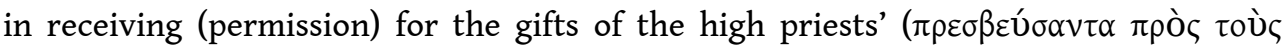

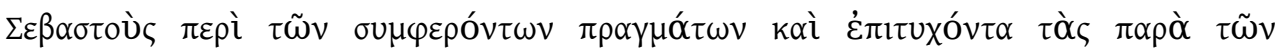

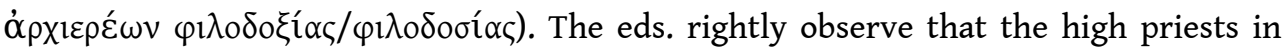
question are not those of Asia but the local priests of the imperial cult. Ruso probably 
acquired through his embassy permission for the organization of munera ( $\left.\varphi \imath \lambda_{\circ} \delta \circ \xi \xi \alpha_{l}\right)$ by the high priests.

50) C.A. FARAONE, "A Socratic Leaf Charm for Headache (Charmides 155b-157c), Orphic Gold Leaves, and the Ancient Greek Tradition of Leaf Amulets", in Myths, Martyrs, and Modernity, p. 145-166: In Plato's Charmides Socrates describes a remedy for headache that combines the application of a leaf and the singing of an incantation; he attributes this procedure to Thracian healers, and explains that the pain should also be treated with incantations. F. argues that the background of this procedure is provided by the Orphic gold leaves of the late Classical or early Hellenistic period, which were ivyshaped and inscribed with hexametrical verses (see texts from Pelinna, Aigion, Elis, and Pella: SEG XXXIV 338; XXXVII 497; XLI 401; XLII 619; LII 470/471). With regard to two

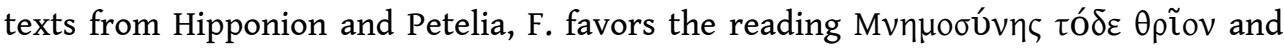
recognizes here a reference to a large leaf ('this is the leaf of Memory. Whenever he is about to die, let him write this on a golden tablet and carry it'). The text of Petelia was found worn as an amulet by its final owner, who had inherited it as heirloom; the owners of this leaf must have thought these verses to mean that they would protect the owner when his life was in danger. Therefore, the extant Orphic leaves had the same range of therapeutic and eschatological powers as Socrates' combination of leaf and incantation. In the Roman period, leaf amulets with prophylactic and healing properties were often recommended by magical handbooks. Interestingly, the earliest leaf amulet invokes a Dionysian myth about the Thracian king Lykourgos.

51) C. FARAONE, "Hexametrical Incantations as Oral and Written Phenomena", in Sacred Words, p. 191-204: The oral performance of hexametrical incantations is an early phenomenon attested through literary sources. E.g., in the Homeric Hymn to Demeter 227-230, Demeter boasts about her knowledge of protective magic; these verses (esp.

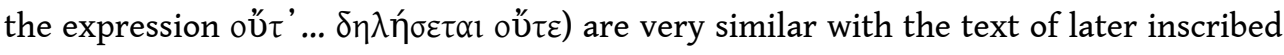
amulets. The amulets do not derive from the hymn but rather the hymn's poet draws on an existing popular tradition. The variety of content and wording suggests that the individual healer had the freedom to adapt an incantation to specific needs. Such incantations were widely diffused from the late Classical period on. Also Aristophanes, Amphiaraus fr. 29 ed. K.-A. seems to be a parody of a hexametrical incantation (cf. Euripides, Cyclops 646-648). By the end of the Classical period hexametrical incantations begin to be treated as written performances as well. The efficacy of the text lies solely in its physical presence as an inscribed text [cf. supra $\left.n^{\circ} 50\right]$. However, the oral performance of hexametrical incantations continued.

52) F. FERRARI, "Oral Bricolage and Ritual Context in the Golden Tablets", in Sacred Words, 205-216: F. asks whether we should respect epichoric versions of the texts on the Orphic tablets or whether we should try to reconstruct an original model. After examining differences between selected tablets, he rejects the existence of a fixed archetype. E.g., the justaposition of two versions of what expects the deceased initiate in the underworld reveals the co-existence of two incompatible concepts: the concept

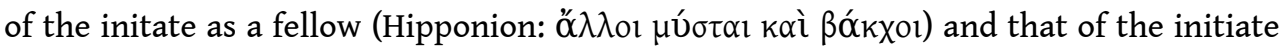
as a ruler (Petelia: $\left.\mu \varepsilon \theta^{\prime} \dot{\eta} \rho \omega \dot{\varepsilon \sigma \sigma l} \dot{\alpha} v \alpha{ }_{\alpha} \xi \varepsilon 1 \zeta\right)$. Instead of attempting to reconstruct an archetype, F. proposes to look for a more flexible model, a 'paleotype', that accounts for the wide range of common traits without suppressing alternatives and variations. His second question concerns the possibility to reconstruct the ritual context of the tablets. He argues that the texts from Pelinna are addressed to the deceased initiate but the 
speakers are two: an earthly one who is instructing the initiate and an underwordly one (Persephone?) who welcomes him. The different speakers and the different rhythmic forms help to establish different scenarios and different pragmatic purposes in the ritual.

53) F. FRISONE, "Construction of Consensus: Norms and Change in Greek Funerary Rituals", in Ritual Dynamics in the Ancient Mediterranean, p. 169-201: F. studies Greek funerary legislation, especially a law from Ioulis (LSCG 97), as evidence for changes and normative interventions in rituals, for the repeated review of existing norms, and for the very diverse agency behind these interventions (R. ARENA, Iscrizioni greche arcaiche di Sicilia e Magna Grecia. III. Iscrizioni delle colonie euboiche, Pisa, 1994, $\mathrm{n}^{\circ}$ 15; CID I 9; LSCG Suppl. 64 + SEG LVII 820; LSAM 16). Funerary rituals represent one of the most important moments in which pride, wealth, and support could be displayed in public; this display of social prestige and rank had to be adjusted to the prevailing social values. The polis, as a community of shared values, had the strength to assert new norms, punishing individual behavior that violated the rules; in some cases the punishment was exclusion from the community.

54) M. GAGARIN, "Writing Sacred Laws in Archaic and Classical Crete", in Sacred Words, p. 101-111: Examining the inscribed cult regulations from early Crete, G. observes that there is no discernible difference between sacred laws and other kinds of laws with regard to the reasons why they were inscribed in public places, the institutions which authorized the inscribing, and the audience of the inscriptions; there is also no indication that what we call today 'sacred laws' were treated in Crete as different in nature from other laws, although the Cretans did differentiate between the sacred and the secular realm. Not only did sacred laws sometimes contain secular provisons but sacred matters were often treated within the context of secular laws. He attributes the publication of laws to the growing size of communities and the need to publicize rules. He examines inscriptions concerning sacrifices from Dreros, Gortyn, and Axos (Dreros: M. BILE, Le dialecte crétois, Paris, 1988,p. 31 no. 8; Gortyn: I.Cret. IV 3; Axos: I.Cret. II.v.9).

55) D.J. GEAGAN, The Athenian Agora. Volume XVIII. Inscriptions: The Dedicatory Monuments, Princeton, 2011 [BE 2012, 42]: This important epigraphic corpus assembles the inscribed dedicatory monuments found in the Athenian Agora, some of which originally stood on the Acropolis (new texts are marked with an asterisk). 27 texts belong to the Archaic and Classical period (A1-27). They include the epigram attributed to Simonides in honor of the tyrannicides (A1), a dedication after the victory of the Athenians in Pylos (A2), choregic monuments (A3-A5), an altar dedicated to Athena (A6), and dedications to Apollo (A8: $\delta \varepsilon \kappa o ́$ in), Athena (A13), the Twelve Gods (A9), and anonymous deities (A7, A11* A12, A13*, A15*, A22). An epigram commemorates the dedication of a priestess of Demeter $(A 10=C E G$ 317). A basin for ritual aspersions belonged to the Old Bouleuterion (A25; cf. the ritual basins A26-A27*). With regards to religious matters, the most important group consists of the votive monuments from the late Classical to the Imperial period (V559-704). The recipients are Aphrodite (V559-561; V560: tò $\pi \rho o ́ \sigma \omega \pi \mathrm{ov})$; Apollo (V563, 564, 565*) and Apollo Lykeios (V562); Artemis (V569), Artemis Soteira (V566), Artemis Mounychia (V567), and (Artemis) Kalliste and Ariste (V568); Asklepios (V570, V572*-574*, V575-576; V572* is an anatomical votive representating

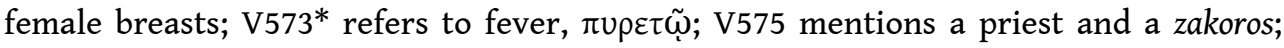
V576 is the paian of Sophocles), Asklepios and Hygieia (V571*), and a healing deity (V577*); Athena (V581; V583: the votive is a statue of Aphrodite and Eros: A $\varphi \rho \circ \gamma \varepsilon v \tilde{n}$ 


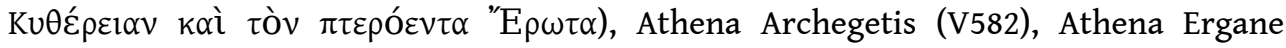

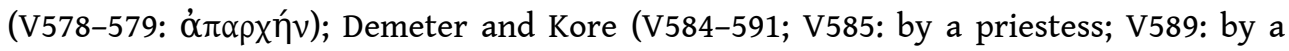
zakoros) [in V591 (2nd cent. CE) one should probably read the names of the deities in the

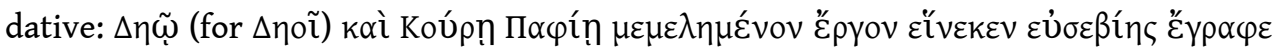

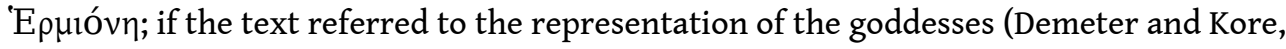
who are assimilated with Aphrodites), their names would be in the accusative, not in the nominative; '̌ $\gamma \rho \alpha \varphi \varepsilon$ cannot be 'sculpted out'; the dedicated work must have been a painting]; Dionysos (V592*-593*: altars); Eileithyia (V594); Euporia (V595); Hebe (V596*); heroes and heroines (V597-598, V599*-601*); Heros Iatros (V602); Mnemosyne

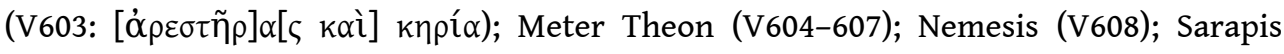

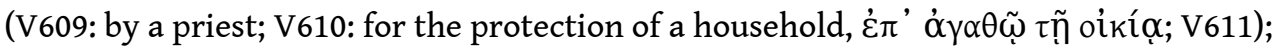
Pantes Theoi (V612: by a priest); a Thea Epekoos (V671); Zeus Hypsistos (V613-617,

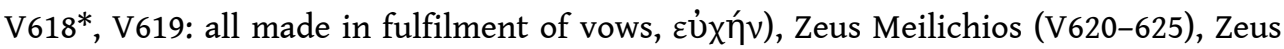
Ombrios (V626-627), Zeus Phratrios and Athena Phratria (V628-629), and Zeus Teleios

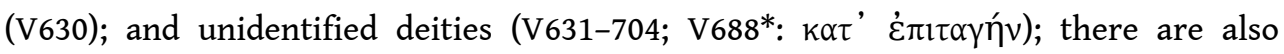
dedications to an eponymous hero of a tribe (C80), Zeus Boulaios and Hestia Boulaia (C109). G. collects separately dedications made on by private and public religious bodies (c113-122). They refer to the sanctuary of Herakles of the genos of the Praxiergidai (C113), the cult of heroes (C114-116: C115: by eranistai; C117: by a group of $\theta \varepsilon \rho \alpha \pi \varepsilon v \tau \alpha i ́$ in connection with either the cult of Asklepios or that of the Egyptian gods), the Eleusinian mysteries (C121: list of initiates $\left.\alpha^{\prime} \varphi^{\prime} \dot{\varepsilon} \sigma \tau i ́ \alpha \varsigma\right)$, the cult of Asklepios (C122: list of paianistai and reference to the inscribing of a paian for Asklepios and Koronis).

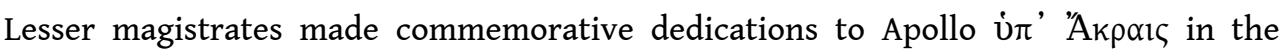
Imperial period ( $\mathrm{C} 45-\mathrm{C} 76$; most of these are inedita). Another large group commemorates victories in ephebic contests and in torch races (C124-C146). When the addressee is mentioned it usually is Hermes (C126, C128, C131, C132, C135-136) and in one case the Muses (C130). A few agonistic inscriptions record victories in various agonistic festivals that we cannot list here (C195-208, no inedita). The choregic monuments are also connected with the agonistic culture (C173-194). The most important among them is one that commemorates a victory of the Leontis (C187), possibly in a contest connected with the cult of Asklepios; part of the inscription quotes the text of a poem, probably composed by Sarapion, describing the duties of doctors (C187, late 1st cent. CE). The monument was re-dedicated in ca. 140-160 CE, when a portrait of Sarapion was set up; on that occasion, a paian composed by him was inscribed under his portrait (H377). Many monuments were military in character (C147-172: 156: to Demeter and Kore; C162*, 166, 168: to Heros Strategos). Honorific statues were dedicated to Demeter and Kore (H320, 323, 326, 330, 340, 351). Other texts that commemorate services and victories include dedications by Athenian cleruchs (C32*, C33-C34); dedications by magistrates, bodies of officials and civic subdivisions (C35-C44); dedications by prytaneis and civic, tribal, and deme magistrates (C77-112). Building inscriptions (C209-224) mention construction works pertaining to the Panathenaic Road (C 210), a building dedicated to Demeter and Kore (C216), a library

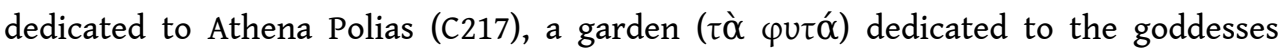
Posphoroi (C221), and a dedication to Athena (C222). The imperial cult is represented by altars dedicated to the emperors (H274-281: Augustus; H283: Nero; H284: Vespasian; H285-313: Hadrian; unidentified emperors: H282, H314-315). The texts mention a large number of cult officials: a priest of Artemis for life (H369), a priest of Hephaistos (C122),

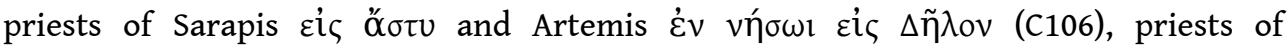


undetermined deities (C118, C122, C123, H319, H382), hierophantai (H359, H365), dadouchoi (H361) of the Eleusinian mysteries, an epimeletes of the mysteries (C101), a pyrphoros $\left(\mathrm{H} 385^{*}\right)$, exegetai $(\mathrm{C} 120, \mathrm{H} 380)$, a hieropoios (C79), a kanephoros of the Pythais (H330, 333) and the Epidauria (H348), zakoroi, kleidouchoi, kanephoroi, and hypozakoroi in the cult of Asklepios (C122, H348), a periegetes and priest of Zeus Polieus (C122), a

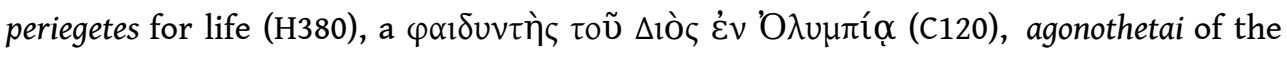
Eleusinia (H346), the Panhellenia (H402), the agon for emperor Claudius (H426), and an unknown contest (H496*); a boy that carried the eresione branch (H370); and the first high priest of the imperial cult in the province Gallia Narbonensis (H398).

56) S. GEORGOUd, "Comment régler des theia pragmata. Pour une étude de ce qu'on appelle "lois sacrées"', in Mètis NS 8 (2010), p. 39-54: G. points out that the modern term leges sacrae ('lois sacrées') is insufficient for the characterization of the texts usually assembled under this term, not only because of the heterogeneity of these documents with regard to content and the authority in which they originate, but also because the texts designated as ífoì vó $\mu$ oı (e.g. LSCG 154 A/B; LSCG Suppl. 45; I.Cret. III.iv.9; IG V.2.5; SEG XI 923) [a new attestation: IG XII.4.1.357] are a much smaller group of texts than what modern scholars call leges sacrae - e.g. the regulation of the mysteries of Andania is labeled as a $\delta i \alpha ́ \gamma \rho \alpha \mu \mu \alpha$; such hieroi nomoi often explained the ancestral customs (patria). The term 'règlement religieux' would be more appropriate [we use the term 'cult regulations', which is broader, since it comprises regulations concerning the funerary cult]; for such norms, both written and orally transmitted, the Greeks used

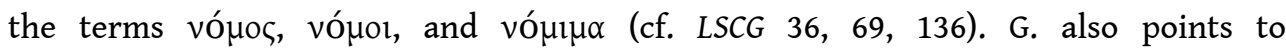
inconsistencies in the modern criteria used for the inclusion or exclusion of documents (e.g. the exclusion of I.Oropos 290). As problems related with the study of religious regulations, G. mentions the variety of content; the conditions under which a community (city, deme, association etc.) decided to write down the regulation (e.g. the re-organization of a cult; see LSCG 151; the introduction of new festivals; see LSAM 96 and 33; the financial re-organization of a cult; see LSCG 15); questions of space (where the regulation was published, where the cult took place; e.g. LSCG 18 and 70); questions of time (especially references to earlier regulations and later additions; e.g. LSCG 21).

57) S. GEORGOUDI, “Quelles victimes pour les dieux? À propos des animaux 'sacrifiables' dans le monde grec", in M.-T. CAM (ed.), La médecine vétérinaire antique. Sources écrites, archéologiques, iconographiques, Rennes, 2007, p.35-44: Based on the information provided by a large number of cult regulations, G. gives an overview of the criteria used for the selection of sacrificial animals (dokimasia, kritos/krite) [cf. EBGR 2010, 59]: physical integrity, beauty, color, age, the relation between a divinity and an animal, the economic possibilities and commercial capacity of a community and its ecosystem, as well as considerations of prestige.

58) F. GRAF, "Earthquakes and the Gods: Reflections on Graeco-Roman Responses to Catastrophic Events", in Myths, Martyrs, and Modernity, p. 95-112: The Greeks and Romans conceptualized natural disasters, such as earthquakes, as being sent by the gods, although earthquakes were not always attributed to divine anger. Certain divinities were attributed protective functions against earthquakes (Poseidon Asphaleios), but ideas concerning the divine origin of earthquakes were complex. In the context of a study of various aspects of Greek, Roman, and Christian responses to earthquakes (religious explanation, narratives), G. discusses in detail two inscriptions. A Delphic oracle from Tralleis (I.Tralleis 1) attributed an earthquake to the wrath of 
Zeus and instructed the erection of an altar of Poseidon, addressing him with a series of

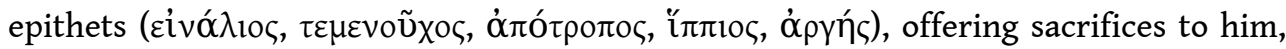
and addressing him in a hymn together with Zeus. A dedicatory epigram in Kos (ca. 200) records the rare occasion in which an earthquake threatened the celebration of the Thesmophoria on 11 Boedromion; the prayers of the dedicant made Demeter and Kore stop the disaster; the dedication was addressed to Demeter Soteira Kore, and Poseidon (R. HERZOG, "Zwei griechische Steinepigramme", Philologische Wochenschrift 52 [1932], 1014).

59) F. GRAF, "Ritual Restoration and Innovation in the Greek Cities of the Roman Imperium", in Ritual Dynamics in the Ancient Mediterranean, p. 105-117: G. discusses three different types of ritual change in the Roman East. 1) The governor Paullus Fabius Maximus proposed measure for the financial administration and the funding of the cult of Artemis in Ephesos (I.Ephesos 17-19, $44 \mathrm{CE}$ ). The costly professional hymnodoi should be replaced by chorus of ephebes; although this was the re-introduction of an old tradition, Paullus did not use tradition as an argument; he only posited economic and educational reasons. 2) In Akraiphia, the local benefactor Epameinondas restored the festival and contest of Apollo Ptoios (IG VII 2712, mid-1st cent. CE) after an interruption of thirty years [see EBGR 2010, 35 and 182]. In addition to performing sacrifices, the procession, and the traditional dance syrtoi ('those in long trailing robes'), Epameinondas expanded the scope of the festival by associating it also with the imperial cult. 'This manipulation of the ritual tradition, combining reconstruction with innovation, illustrates the ambivalent status of the new civic elite of the Greek cities: they furthered the status of their cities in a Greek world where the past was the most valuable commodity whilst at the same time furthering the interest of the new ruling power, Rome'. 3) With the procession established by C. Vibius Salutaris in Ephesos (I.Ephesos 27A, $104 \mathrm{CE}$ ) we have a case of a true innovation, the introduction of a new ritual staged by an Ephesian citizen with the rank of a Roman knight in order to display the political and ideological structure of Ephesos. His innovation did not lie in the cultic form - the procession - but in the intricate complexity of the representation. In all three cases, ritual was manipulated to respond to contemporary needs. The agents were a governor and wealthy citizens with close connections to Rome; they could mediate the complex interplay between city and court. While Epameinondas stressed the traditional nature of his restoration, Salutaris highlighted the proud self-display and self-assertion of a powerful city under the empire.

60) D. GRANINGER, "IG IX.2 1099B and the Komai of Demetrias", ZPE 177 (2011), p. 119-122 [BE 2012, 259]: A decree from Demetrias (IG IX.2.1099 B, 3rd cent.) concerns a sacrifice and a banquet; their performance is designated as 'a record for the polis' piety towards

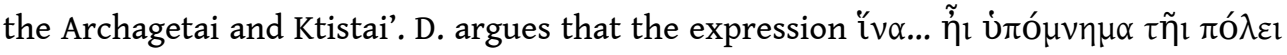

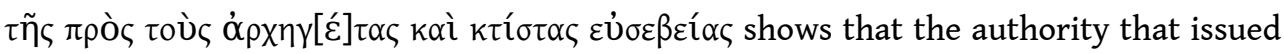
the decree and displayed piety was different from the polis; it may have been a village of Demetrias. [This interpretation is based on two misunderstandings. First, a text that distinguishes between those who display piety and the audience of their display clearly

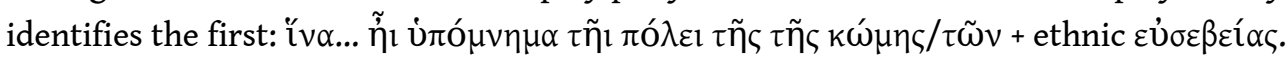
Since such an identification is missing, the piety can only be that of the polis; Demetrias

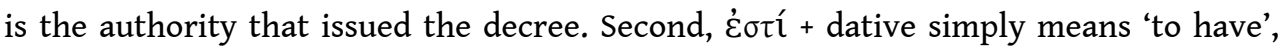
not to 'show to'. The translation is: 'so that the polis has a memorial of its piety towards the founders'; see also the critical remarks of J.-C. DECOURT, B. HELLY, BE 2012, 259]. 
61) D. GRANINGER, Cult and Koinon in Hellenistic Thessaly, Leiden, 2011 [BE 2013, 224]: G. examines the role played by cult in the construction of identity by the Thessalian Koinon in the 2nd and 1st cent. G. includes under the term 'Thessaly' the Tetrades of the Thessalians, the adjacent regions of Magnesia, Perhaibia, and Achaia Phthiotis, and the smaller ethne on the periphery of Thessaly. After reconstructing the history of 'broader Thessaly', G. studies the federal sanctuaries (p. 43-86), focusing on the importance of the cults of Athena Itonia at Philia and Zeus Eleutherios in Larisa for the regional identity of the Thessalians. G. then argues that the festival of Zeus Eleutherios was introduced not only as a celebration of the Thessalians' freedom but also as a conscious response to the Eleutheria of Plataia. The agonistic program of this festival, known from inscriptions, highlighted local traditions (e.g. the competition called a 'torch race on horseback' and the bull hunt). As regards the cult of Athena Itonia and the Itonia festival, G. explains why the sanctuary at Philia - and not another sanctuary of Athena Itonia - acquired federal status after 196 BCE thus: 'it lay near the mythic migration route of Thessaloi from southern Epiros and staked a strong claim to territory that in recent decades had been the site of friction between Macedon and Aitolia' (p. 44). [But contrary to G.'s assumption that Itonos was in Achaia Phthiotis (p. 55-58), it is now almost certain that Itonos is the ancient name of Philia and that this sanctuary had federal status already in the 3rd cent. BCE. This was the place whither the Koan theoroi to Thessaly were sent (SEG LIII 849, ca. $242 \mathrm{BCE}$ ) and, as a new text from Aigai informs us (EBGR 2009, 98; SEG LIX 1406; see infra ${ }^{\circ}$ 97), also the place where the Thessalian Koinon published its decree concerning the federal festival of Zeus Olympios]. In the chapter 'The Thessalian Calendars' (p. 87-114), G. discusses the development of a common calendar in 'tetradic Thessaly' shortly after $196 \mathrm{BCE}$ and its introduction to the ethne that were gradually incorporated into the Thessalian League. In the chapter 'International Religion' (p.115-151), G. studies the network of religious relations between the Thessalians and other Greeks (participation in the Delphic amphictyonic council, dispatch of sacred envoys, participation of Thessalians in panhellenic agonistic festivals, participation of foreigners in Thessalian festivals). G. argues that a sense of unity co-existed with clear differentiations between 'tetradic Thessaly' and the new members of the Thessalian Koinon. For instance, the latter did not attend the Itonia and Eleutheria; they sent their own amphictyones to Delphi; they reluctantly accepted the Thessalian calendar; and as the case of Ainais shows (p. 153-158), they kept their individual cultic traditions. In an Epigraphic Appendix (p. 159-182), G. presents critical editions, translations, and commentaries of seven victor lists at the Eleutheria of Larisa and a victor list for a dramatic festival in Larisa, which permit the reconstruction of the pentaeteric Eleutheria [for a detailed critical discussion see J.-C. DECOURT, B. HELLY, BE 2013, 224].

62) M. HAAKE, "Antigonos II. Gonatas und der Nemesistempel in Rhamnous. Zur Semantik göttlicher Ehren für einen hellenistischen König an einem athenischen 'lieu de mémoire"', in M. HAAKE, M. JUNG (eds.), Griechische Heiligtümer als Erinnerungsorte von der Archaik bis in den Hellenismus. Erträge einer internationalen Tagung in Münster, 20.-21 Januar 2006, Stuttgart, 2011, p. 109-127: A decree of Rhamnous (SEG XLI 75, ca. 262-240 BCE) established a sacrifice to King Antigonos Gonatas on 19 Hekatombaion, during the athletic contest of the Megala Nemesia. As $\mathrm{H}$. argues, the association of Antigonos with Nemesis had a political significance connected with the importance of her sanctuary as a place of memory: the goddess had punished the Persian hybris in the battle at Marathon. Only a few years earlier (ca. 267 BCE) the opponents of the Macedonians had 
assimilated Antigonos' policies with the Persian invasion. After his victory in the Chremonidean War, he was honored by the Rhamnountians as the man who had defeated the new barbarian aggressors, the Celts. His victory over the Celts was assimilated with the victory of the Athenians over the Persians.

63) A. HeLLER, "Les bêtises des Grecs". Conflits et rivalités entre cités d'Asie et de Bithynie à l'époque romaine (129 a.C.-235 p.C.), Bordeaux, 2006: A large part of H.'s study is dedicated to disputes concerning the title of the neokoros of the imperial cult and the title of the metropolis (p. 179-282).

64) S. HITCH, "Embedded Speech in the Attic Leges Sacrae", in Sacred Words, p. 113-141: Greek cult involved a lot of spoken communication, speech acts, prayers, and other oral performances, for which often no direct evidence exists [cf. EBGR 2010, 36, on acclamations]. $\mathrm{H}$. recognizes evidence for such oral performances in Attic cult

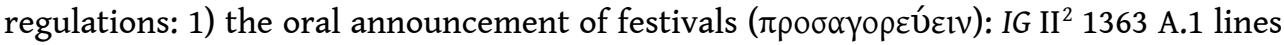
1-6 (Пропро́

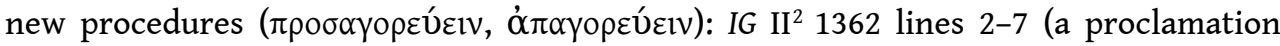
concerning measures against the deforestation of a sanctuary); 3) invitations to

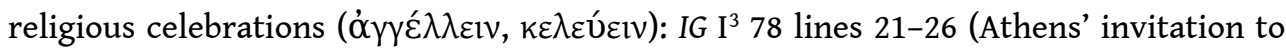
the Greeks to contribute to the aparche; cf. IG II ${ }^{2} 1235$ lines 2-7); 4) exegesis ( $\dot{\varepsilon} \xi \eta \gamma \varepsilon \tilde{\tau} \sigma \theta \alpha \mathrm{l}$, $\lambda \varepsilon \dot{\gamma \varepsilon I v): ~ I G ~} \mathrm{II}^{2} 47$ lines 23-30; 403 lines 16-20. 5) prayers and vows (inscriptions recording the performance of prayers on behalf of the Athenians): e.g. IG II ${ }^{2} 410$ lines 211. This evidence draws attention to the authoritative role of priests as ritual performers in Athens, and also to the importance of priesthoods of gene and oral traditions.

65) A. Hollmann, "A Curse Tablet from Antioch against Babylas the Greengrocer", ZPE 177 (2011), p. 157-165: Ed. pr. of a defixio from Antioch (3rd/4th cent.). The tablet is inscribed on both sides with two different curses against a greengrocer; the first curse uses a historiola, the second the similia similibus motif. That the historiola refers to Exodus 11-12 and 14-16 is not sufficient reason to identify the author of the defixio as a Jew [we present the Greek text in standard Greek orthography]. Side A: ' (Magical words) O

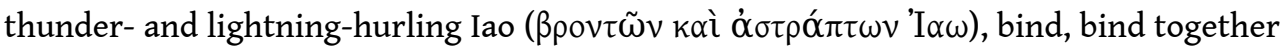

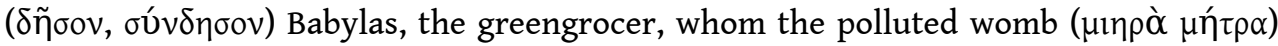
Dionysia, also called Hesychia, gave birth to and who lives in the neighborhood of the Mygdonites. As you struck the chariot of Pharaoh, so strike his offensiveness [M. ARBABZADAH, “A Lexicographical Note on a Curse Tablet from Antioch”, ZPE 179 (2011),

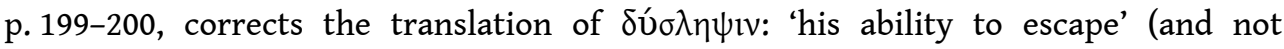
'offensiveness')]. $O$ thunder- and lightning-hurling Iao, as you cut down the firstborn of Egypt, cut down his [livestock] as much as [- - now and bind, bind down, bind together,

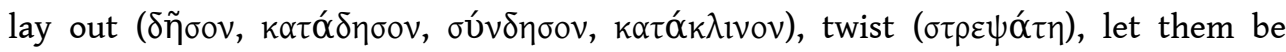
broken, let them not be able to move, the livestock of Babylas himself all the time from this hour and from this day, now, now, quickly, quickly, fill with evil fortune and

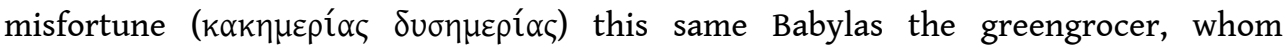

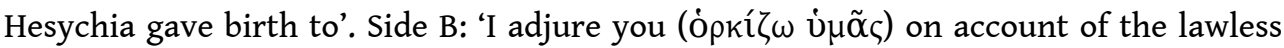

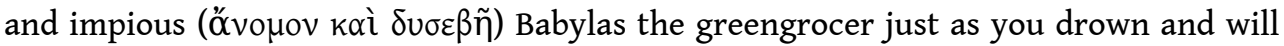
chill this tablet in the disused well, so too drown and chill the soul of Babylas ( $\beta \omega \lambda i$ í $\alpha \tau \varepsilon$

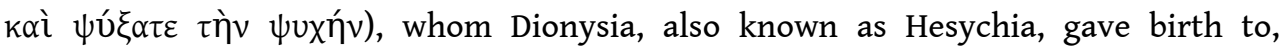

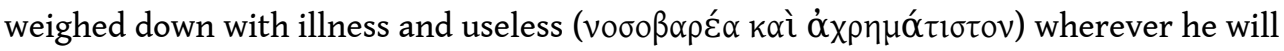

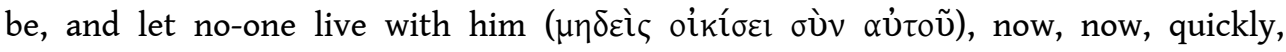




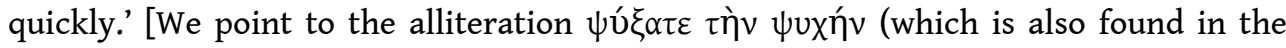
Orphic tablets) and to the effort of the author to justify the curse by characterizing the mother of Babylas as 'an impure womb' and Babylas as lawless and impious].

66) F. HUMER, G. KREMER (eds.), Götterbilder - Menschenbilder. Religion und Kulte in Carnuntum. Katalog zur Ausstellung im Rahmen der Niederösterreischen Landesausstellung 2011 im Archäologischen Museum Carnuntinum, Bad Deutsch-Altenburg 16. April bis 15. November 2012, Vienna, 2011: This catalogue contains two inedita: two lead round pendants with the representation of a demon with the head of a cock and legs of a

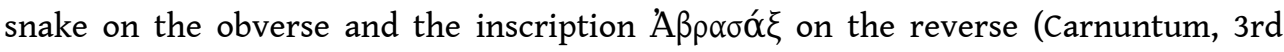
cent. CE).

67) J. HUPE, "Der Dedikantenkreis des Achilleus als ein Gradmesser von Akkulturationsprozessen im kaiserzeitlichen Olbia. Ein Beitrag zur olbischen Onomastik", in F. FLESS, M. TREISTER (eds.), Bilder und Objekte als Träger kultureller Identität und interkultureller Kommunikation im Schwarzmeergebiet, Rahden/West., 2005, p. 27-42: Olbian magistrates started making dedications to Achilles Pontarches from the late 1st cent. CE onwards; this cult was connected with the political and religious institution of Olbia. The dedications provide lists of names, mostly with Greek names. The presence of Iranian names became stronger after ca. $200 \mathrm{CE}$ because of intermarriage between Greek and Iranian population and other demographic developments, but the use of the Greek language and the loyalty towards the main civic cult indicate a high degree of Hellenization.

68) A. IVANTCHIK, "Greeks and Iranians in the Cimmerian Bosporus in the Second/First Century BC: New Epigraphic Data from Tanais", in S.M.R. DARBANDI, A. zouRnATzI (eds.), Ancient Greece and Ancient Iran. Cross-cultural Encounters, 1stInternational Conference (Athens, 11-13 November 2006), Athens, 2008, p. 93-107: In a discussion of the co-existence of Greeks and Iranians in Tanais, I. presents three inscriptions of cult associations (thiasoi, 2nd/1st cent.). The first decree mentions the officials of an association of thiasitai: priest (restored), pater synodou, philagathos, neokoros. I. discusses in detail the function of neokoroi in the Greek world. The second inscription seems to be connected

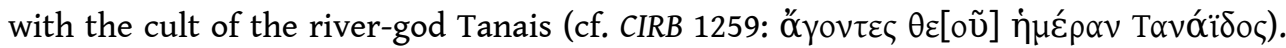
The third text is an honorary decree of a thiasos [for these inscriptions see A.I. IVANTCHIK, VDI 265 (2008), p. 57-72, and SEG LVIII 782-784].

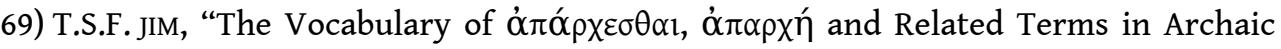
and Classical Greece", Kernos 24 (2011), p. 39-58: A study of the various uses of the

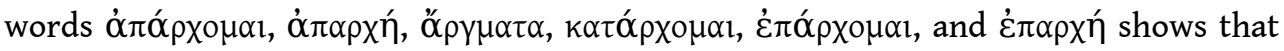
this vocabulary of offering the 'first portion' could be used in relation to sacrifice, dedications, and hair-offerings. The offering could be both a sacrificial portion and a first offering. The common denominator is the act of setting aside a portion as a symbolic offering expressing the precedence of the gods over humans. While

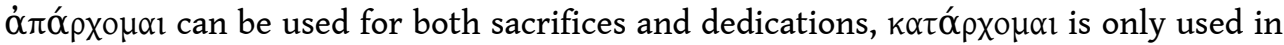
connection with sacrifice and $\dot{\alpha} \pi \alpha \rho x \eta ́$ is predominantly used in the context of dedications.

70) C.P. JONES, “An Apamean at Philippopolis”, ZPE 176 (2011), p. 96-98 [BE 2011, 437]: A funerary epigram from Philippopolis honors a certain Maximos of Apameia, buried near a statue of Apollo Kendrissos. N. Sharankov identified him with a homonymous Apamean poet, twice winner of the Hadriana Olympia in Kyzikos [EBGR 2007, 133]; he 
based his assumption that Maximos was a poet participating in agonistic festivals on

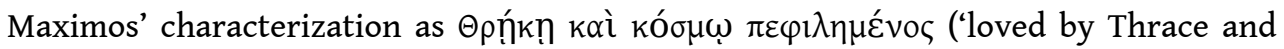
the world'). J. expresses doubts on both this identification and the assumption that Maximos was a poet: 'If he was a poet, the wretched versification would suggest that his command of meter had not passed to his son'. It is more likely that he was a trader. Maximos' fatherland must have been Apamea Myrleia (Mudanya, at the entrance of the Gulf of Kios).

71) C.P. Jones, “Cleopatra VII in Teos?”, Chiron 41 (2011), p. 41-53 [BE 2012, 356]: Ed. pr. of an inscribed altar copied by J. and L. Robert in Teos in 1955 (now probably lost). A woman dedicated an altar of Berenike Thea, Arsinoe Thea, Kleopatra Thea, and Queen Kleopatra. The mention of a dedicant shows that it was not used for a domestic cult. The letter-forms suggest a date between 125-25 BCE. The reigning queen most probably is Kleopatra VII and the date ca. 33 BCE. The deified relatives are probably Berenike I, Arsinoe II, and Kleopatra, the daughter of Ptolemy IV, who married three Seleucid kings. The existence of this 'elder' Kleopatra (worshipped in Ptolemais in Phoenicia as Kleopatra Thea Eueteria) explains the designation of Kleopatra VII as Neotera (the 'younger' Kleopatra). Kleopatra's association with her homonymous relative emphasized her claim to be a new Lagid queen in Syria. However, J. points out that other identifications of Thea Kleopatra (Kleopatra Tryphaina) cannot be excluded. As a seat of the Dionysiac artists, Teos had close connections with Marc Antony, the new Dionysos, and the Ptolemaic court. The inscription was found near Dionysos' temple. In an appendix, J. briefly discusses a dedication made to Aphrodite Epekoos by a priest on behalf of King Demetrios I of Syria, Queen Laodike, and their children (SEG L 1462; EBGR 2000, 78). J. suggests that the priest (of Aphrodite), who was worshipped as a patron of maternity in Teos, made the dedication to thank the goddess for blessing the royal couple with sons.

72) D.R. JORDAN, E. PACHOUMI, "A Gold-foil Phylactery from the Hermus Valley in the Manisa Museum", EA 44 (2011), p. 163-164 [BE 2013, 46]: An inscribed gold lamella in the Manisa Museum (I.Manisa 488), which has been tentatively interpreted as an Orphic

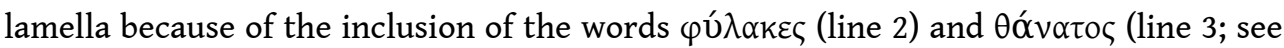
EBGR 1994/95, 225; 2000, 16), is in fact a phylactery. The text cannot be reconstructed,

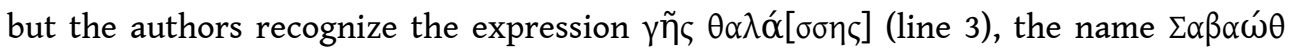

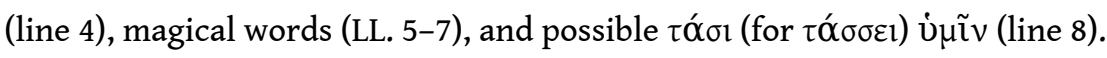

73) A. KLÖCKNER, “Women's Affairs? On a Group of Attic Votive Reliefs with Unusual Decoration", in Myths, Martyrs, and Modernity, p. 179-191: K. studies a group of six votive reliefs from Athens (Brauron, Rhamnous, Teithras?, Athens?, 4th cent.); a similar relief was found in Megara. The decoration consists of two oblong objects arranged in an X; there is a rounded knob in the middle, where they are joined together. At the curved ends, they usually have small crescent bulges. Some of them are inscribed. According to the inscriptions, they were dedicated by women, one on behalf of her child, another to Artemis, another one to the Eleusinian goddesses. The three reliefs from Rhamnous were probably dedicated in the Telesterion, another may be from the Koreion in Teithras. K. compares the enigmatic object with representations of cross-torches in Sicily. Such torches were supported by a long stick and burned on four ends; they seem to have been a requisite in the cult of Demeter, Kore, and Artemis [obviously used in nocturnal ceremonies]. 
74) S. KRAVARITOU, "Synoecism and Religious Interface in Demetrias", Kernos 24 (2011), p. 111-135 [BE 2013, 245]: K. examines the process of the creation of the city of Demetrias and the organization of the religious life of the new city. Traditional Thessalian cults were incorporated into the cults of Demetrias (Hermes Chthonios, Ennodia, Herakles, Artemis Iolkia) along with religious innovations, such as the amalgamation of Pasikrata with Ennodia, the introduction of new cults (Herakles Kynagidas, Demeter, Kore, and Plouton) and the ruler cult of Demetrios Poliorketes and Antigonos Gonatas as archegetai kai ktistai. The sanctuaries of Apollo Koropaios at Korope and Zeus Akraios and Chiron on Mt. Pelion continued to exist as extra-urban sanctuaries of Demetrias. In two tables, K. collects the evidence for cults in the area of Demetrias and Pagasai in the Archaic-Classical (p. 125-128) and Hellenistic-Imperial periods (p. 128-133).

75) G. LABARRE, Le dieu Mèn et son sanctuaire à Antioche de Pisidie, Brussels, 2010: L. summarizes the literary, archaeological, and epigraphic sources for the god Men (p. 2131) and discusses in detail his iconography and attributes, his epithets, which often refer to the founder of the cult or a place of worship, his functions as a protector of humans, his association with other gods, and the rituals in his cult (prayer, libations, offerings), and the origins of the cult (p.32-69). He also gives an overview of the topography and architecture of his sanctuary in Antiochia in Pisidia (p. 71-113), the cult personnel and the worshippers (p.115-146), and the diffusion of relevant theophoric names (p.146-154). In an appendix, he presents a small selection of relevant inscriptions.

252 76) E. LAfLI, E. CHRISTOV, "Der kaiserzeitliche Tempel von Asartepe/Kimistene in der Chora des paphlagonischen Hadrianopolis - Ergebnisse der Prospektion von 2005", MDAI (I) 61 (2011), p. 233-286: The authors present the epigraphic finds from Asartepe (ancient Kimistene in the territory of Hadrianopolis) [from the ethnic Kimestenos one may infer that the place name was Kimesta, not Kimestene]; new texts are marked with

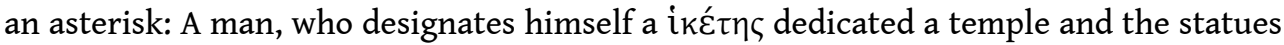

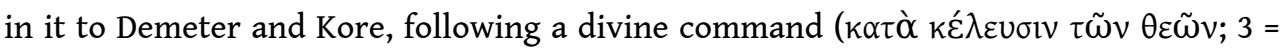
SEG XXXIII 1100, $196 \mathrm{CE}$ ). Other dedications are addressed to Zeus Kimistenos ( $4=$ SEG XXXIII 1099, 2nd cent. CE), Zeus Bronton (5*; dedication of a $\pi \lambda ı v \theta i ́ \varsigma$ and a $\kappa \alpha \mu \alpha ́ \rho \alpha)$ [a threshold and an arch or vault]. The remains of a temple, built in the late 2nd or early 3rd cent. CE, must be attributed to Zeus Kimestenos, whose cult is also attested through Greek and Latin inscriptions in Dacia.

77) B. LE GUEN, “Comment parler de l'argent des concours grecs ou 'à la grecque'?", in L'argent dans les concours, p. 21-34: L. gives an overview of the history of research on the economic aspects of Greek agonistic festivals and summarizes the main aspects of the subject (expenses for the organization of agones, private and public sources of funding, rewards for the victors).

78) V. LIAPIS, "The Thracian Cult of Rhesus and the Heros Equitans", Kernos 24 (2011), p. 95-104: L. associates the literary evidence for the cult of the Thracian king Rhesos (Ps.-Euripides, Rhesos 962-973; Philostratos, Heroikos 18.3-6) with the cult of the Thracian Rider. Admittedly, Rhesos is never given as the name of the Thracian Rider, but $\rho \tilde{\eta} \sigma o \varsigma$ probably is not a name but a designation meaning 'lord' (cf. the designation

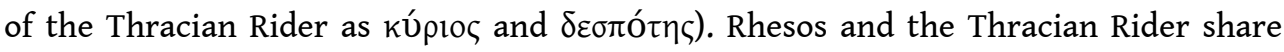
traits as healing deities, horse masters, hunters, and chthonic figures. Although the 
identification of the Thracian Rider with Rhesos cannot be proven on the basis of the existing evidence, it should not be ruled out.

79) J.-J. MAFFRE, A. TICHIT, "Quelles offrandes faisait-on à Artémis dans son sanctuaire de Thasos?", Kernos 24 (2011), p. 137-164: The authors give an overview of the dedications made to Artemis in her Thasian sanctuary. Although it is evident that the goddess was worshipped as a patron of women, the dedicatory objects do not show any specific connection with Artemis and do not permit a precise definition of her properties. The discovery of skyphoi and kylixes as well as of a dedication made by a man (Philon) reveals the participation of men in the cult. Some kylixes and skyphoi have dedicatory

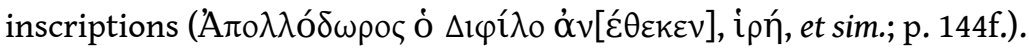

80) C. MAREK, "Zur Epigraphik von Pompeiopolis: Eine Zwischenbilanz", in L. SUMMERER (ed.), Pompeiopolis I: eine Zwischenbilanz aus der Metropole Paphlagoniens nach fünf Kampagnen (2006-2010), Langenweißbach, 2011, p. 189-191: M. gives an overview of the inscriptions of Pompeiopolis. 34 new finds can be added to the catalogue published in 1993 [see the summary in EBGR 1993/94, 153]. The main god of the city was Helios, associated with Zeus and Sarapis. M. presents three new finds. 1) A man offered a

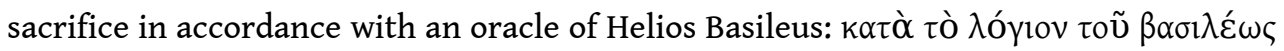

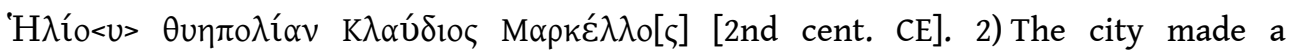

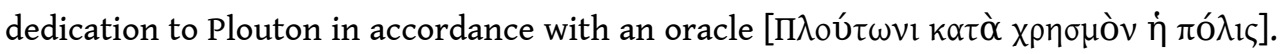

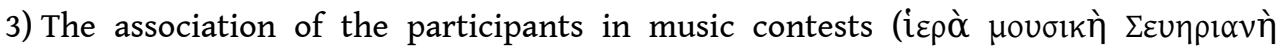

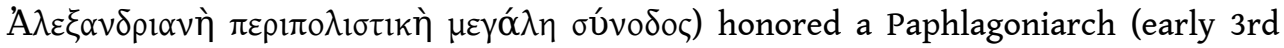
cent. CE).

81) Á. MARTÍNEZFERNÁNDEZ, "Una inscripción votiva inédita de Áptera", in F. CORTÉs GABAUDAN, J.V. MÉNDEZ DOSUNA (eds.), DIC MIHI, MUSA, VIRUM. Homenaje al prefesor Antonio López Eire, Salamanca, 2010, p. 413-418: Ed. pr. of a dedication to Hestia by a damiourgos,

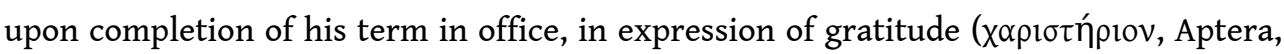
2nd cent.). The cult of Hestia is well attested in Crete. Dedications to Hestia by magistrates after their term in office are common: e.g. IG XI.4.1137/1138, 1140/1141; I.Ephesos 1065; TAM II.3.1185.

82) P. MARTZAvou, "Les cultes isiaques et les Italiens entre Délos, Thessalonique et l'Eubée", Pallas 84 (2010), p. 181-205 [BE 2011, 317; 2012, 220]: The strong presence of Italians among the worshippers of the Egyptian gods in Delos is attested through the epigraphic evidence. M. attributes the diffusion of specific forms of this cult to Euboia and Thessalonike to the migration of the Italian traders from Delos, after the disastrous attacks of Mithridates VI and the pirates ( 88 and $69 \mathrm{BCE}$ ). The evidence is very strong as regards Thessalonike: the presence of certain gentilicia, the presence of similar epithets, expressions, and forms of worship in both Delos and Thessalonike (Isis Nike, hydreion, representation of footprints and ears on reliefs), the existence of the office of $\dot{\varphi} \varphi 1 \varepsilon \rho \varepsilon \dot{v} \varsigma$ (attested in Delos, assumed for Thessalonike), and the iconography of Isis Pelagia ('Isis "à la voile"). The evidence that links Euboia with Delos and Thessalonike is less compelling: the presence of certain nomina gentilia in Euboia and Thessalonike (the Salarii and the Herennii), the worship of Sarapis and Osiris, the use of the expression

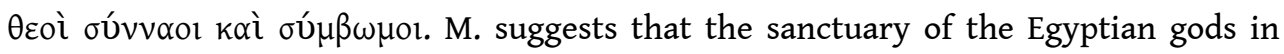
Eretria was abandoned when the Italici were attracted by the advantages offered by Thessalonike [see the critical remarks of D. KNOEPFLER, BE 2012, 220]. 
83) P. martzavou, "Priests and Priestly Roles in the Isiac Cults: Women as Agents in Religious Change in Late Hellenistic and Roman Athens", in Ritual Dynamics in the Ancient Mediterranean, p. 61-84: Focusing on the evidence for the cult of Isis in Athens and Delos, M. studies the complex issue of religious agency in this cult, as represented not only by the activities of priests and priestly officials but also that of devotees ('religious enthusiasts'). After inspection of the sources, M. argues that a significant portion of the Isis devotees assumed some sort of freelance priestly status ('sacerdotization') through ceremonies of initiatory character. This allowed them to be represented in their funerary reliefs as performers of rituals. M. discusses in detail the Athenian reliefs with women in the Isis dress, holding a sistrum; some of them were foreigners, possibly freedwomen. The sistrum suggests their involvement in rituals. Various attributes (garlands, cists) point to an internal differentiation and possibly the existence of a hierarchy. M. argues that the cists were a ritual element that was first elaborated on Delos and later influenced Athenian and Eleusinian imagery and practice. She recognizes similarities between Isiac and Eleusinian rituals also in the presence of kanephoroi and a possible case of hieronymy: in an inscribed altar from Delos (RICIS

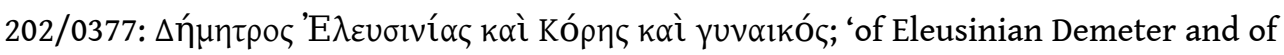
Kore and of (my) wife') the dedicant and his wife remain anonymous; in Eleusinian 'hieronymy' the name of the priest or priestly official was replaced by their title. The omission of the name in the Delian altar might even suggest that the wife of the dedicant was still alive at the moment of the dedication and received some sort of cultic honors. M. proposes the area near the city Eleusinion as the most likely location for the sanctuary if Isis, without excluding the possibility that initiates and 'priest-like' figures in the Isiac cult received intra-shrine burial.

84) V. MATHE, "Coût et financement des stades et des hippodromes", in L'argent, p. 189223: The expenses for stadia and hippodromes made an important part of the budget of ancient agonistic festivals. M. presents a very useful overview of the various expenses and the diverse ways they were covered. The primarily epigraphic evidence is summarized in 9 tables in an appendix (p. 204-223). The main expenses were caused by the construction of stadia and hippodromes, their facilities (e.g. starting mechanisms), and cleaning and repair before and after festivals. Funds were provided by cities, individual benefactors, kings and emperors, priests, gymnasiarchs, the Amphiktyony, and sacred funds of sanctuaries (Epidauros, Argos, Delos).

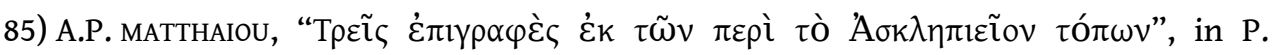

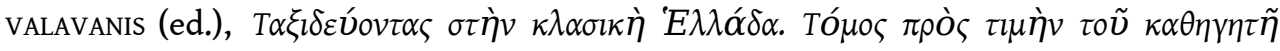

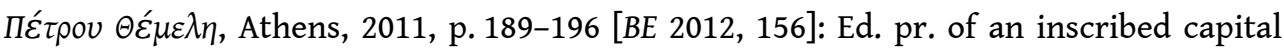
with a dedication to Asklepios (Asklepieion, Athens, ca. 375-350). The dedicant, Leodamas, is known as the dedicant of another dedication to Asklepios found in the south slope of the Acropolis (IG $\mathrm{II}^{2} 4381$ ). In the same article, M. republishes an opisthographic stele (IG I ${ }^{3}$ 1070) from the vicinity of the Asklepieion. Inscribed on the two sides of the stele are the boundary marker of the precinct ( $\left.\tau \varepsilon \dot{\mu} \mu v v_{0}\right)$ of an unknown god (6th/5th cent.) and a fragmentary cult regulation (late 6th cent.). The law forbids the use of a fountain's water for any other purpose than religious rituals (cf. Thuc. IV

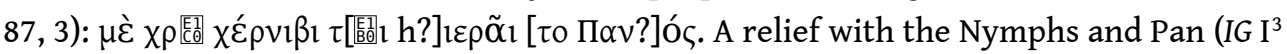
955) suggests the existence of a sanctuary of these deities in this area. If the restoration of the name of Pan is correct, the text must be later than the battle of Marathon. The 
fountain in question may be the Archaic predecessor of a fountain that existed in the Asklepieion (founded in $420 \mathrm{BCE}$ ).

86) J. MeIER, S. TRACY, in S. DIETZ, M. STAVRopoulou (eds.), Kalydon in Aitolia, Copenhagen, 2011 [BE 2012, 46; 2013, 217]: Ed. pr. of an inscription recording the dedication of

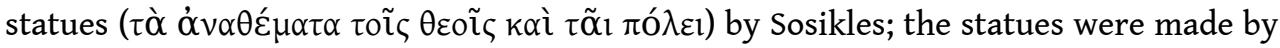
Alexarchos of Sikyon (Kalydon, ca. 150-100; p. 95-97, 122-125). A miniature altar was dedicated to Artemis (p. 147-149).

87) M. MICHALAKI-KOLLIA, "Dédicaces à Artémis Lochia et à Eileithyia à Astypalée. Rapport avec les 2750 enchytrismes des nouveau-nés?", in Epigrammata -- Susini, p. 279-298 [BE $2012,20]$ : The author reports the discovery of an area with more than 2750 vases containing burials of newly born babies, fetuses, and a few infants in Astypalaia (8th cent. BCE to the Imperial period). She associates this unusually large burial place for prematurely deceased babies with the cult of patrons of childbirth: Artemis Lochia and Eileithyia in Astypalaia. A small number of dedications to these goddesses is preserved: 1) Dedication of a temple of Artemis Lochia (early 4th cent.; I.Dor.Ins. 92). 2) Dedication of a statue to Eileithyia by a woman in fulfillment of a vow (IG XII.2.192, early 4th cent.). 3) Dedication to Eileithyia made by a priestess after her term in office (unpublished, 2nd cent.). In order to explain the unusually large number of enchytrismoi of babies, the author observes the presence of a foreign population on this island, as can be inferred from the cults of Atargatis (IG XII.3.178 and 188) and the existence of an association of Phrygians (I.Dor.Ins. 88). She wonders whether the cult regulation preventing entrance of impure people in a sanctuary (IG XII.3.183 = LSCG 130) may be referring to this

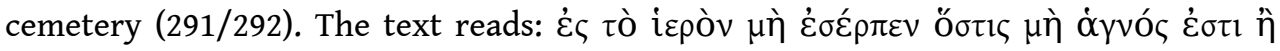

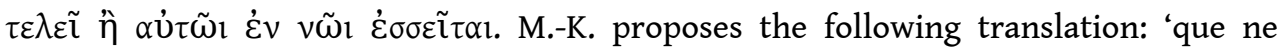
pénètre dans le sanctuaire qui est impur, que ce soit de fait, ou que ce soit en pensée (ou: avec l'intention de l'être)'. By this interpretation, the regulation refers to acts of exposure or abandonment of babies. She suspects that the area of the burials, outside the city wall, may have belonged to a sanctuary of Artemis Lochia, where women deposited their stillborn or prematurely deceased babies and placed them under her protection (p. 291f.). She speculates that this sanctuary was also designed for women who, having lost their children, were considered impure and had to be re-integrated into society (p. 294). [This find is indeed extraordinary and puzzling. However, the author's assumptions cannot be accepted. First, it is unlikely that a sanctuary included a place for burials. Second, the cult of a foreign deity (Atargatis) was not necessarily introduced or practiced by foreigners. Second, an association of the cult regulation with the intentional abandonment of babies is absolutely impossible. The text does not

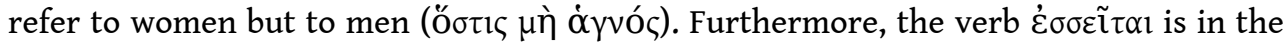
plural; therefore, it cannot refer to a person's condition when entering the sanctuary. It refers to the consequences of his/her action. In my view $\alpha \dot{U} \tau \tilde{\omega} l \dot{\varepsilon} v v \tilde{\omega} l \dot{\varepsilon} \sigma \sigma \varepsilon \tilde{\tau} \tau \alpha_{l}$

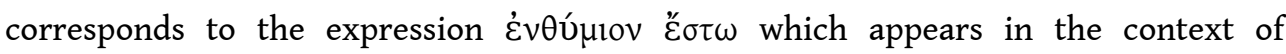
transgression and divine punishment in cult regulations and imprecations from Thasos, Kos, and Knidos, i.e., in the same geographical area. As K. Karila-Cohen has suggested, 'il s'agit d'un sentiment de danger impliquant l'action d'une puissance supérieure' (see EBGR 2010, 93, with reference to the sources). The correct interpretation was already

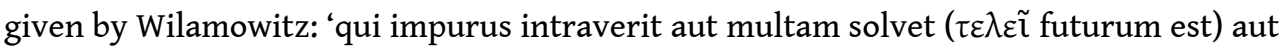

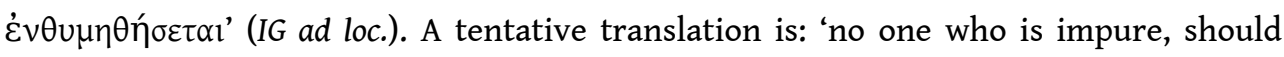
enter the sanctuary; otherwise he shall pay a fine or shall bear this in his conscience']. 
88) L. MigeotTE, "Le financement des concours dans les cités hellénistiques: essai de typologie", in L'argent dans les concours, p. 127-143 [BE 2011, 165]: Focusing on the epigraphic sources concerning the financial aspects of contests in Delos (Apollonia, Posideia), Amorgos (Itonia), Anaktorion (Aktia), Ilion (festival of Athena), Iasos (Dionysia), Bargylia (festival of Artemis Kindyas), Tanagra (Sarapieia), and Lebadeia (Basileia), M. gives a panorama of the various methods used for the funding of contests: use of sacred funds, endowed money, regular public budget, private contributions in the form of liturgies, individual dues, contributions by generous private sponsors.

89) M. MILI, "The Thessalian Ainians or the Ainians of Thessaly? Dedications and Games of Identity", ZPE 176 (2011), p. 169-176 [BE 2012, 258]: A series of dedications from Mikro Keserli in northeast Thessaly (2nd cent. BCE-1st cent. CE) reveal, according to M., an interest in local myths and cults connected with the tribe of the Ainians (IG IX. 2.1058, 1060-1063). Most dedications were made by guards. They are addressed to Aphrodite, Artemis and Artemis Phosphoros (4 texts), Asklepios, Dionysios Kaprios, Herakles, Zeus Perpheretas (3 texts), Leukatas (Apollo?), and the heroes Aineas (3 texts) and Dikaios. Although some of the recipients of the dedications (e.g. Aineas and Zeus Perpheratas) have connections with Macedonia and Thrace, M. argues that both the dedicants and the cults were local.

90) E. MIRANDA, F. GUIZZI, "Le iscrizione”, in T. RITTI, H.H. BAYSAL (eds.), Museo Archaeologico di Denizli-Hierapolis. Catalogo delle iscrizioni greche e latine. Distretto di Denizli, Naples, 2008, p. 33-336 [SEG LVIII 1505; BE 2010, 554]: M. and G. present a catalogue of the inscriptions in exhibition in the new Archaeological Museum of Denizli-Hierapolis. Except for a text from Priene (EBGR 1988, 114; SEG XXXVII 994), all the inscriptions are from Phrygia. We mention the inedita and a few important texts. Laodikeia: An honorific decree of Stratonikeia for Laodikeia (3; SEG LVIII 1541, 3rd/2nd cent.) grants the envoy from Laodikeia the privilege of prohedria in all musical contests [P. HAMON, BE 2010,554 , argues that the prohedria was granted to all the Laodikeians; the invitation was announced by the agonothetes or the hierokeryx]. Attouda: Honorific inscriptions for a priest of Apollo (55, 2nd cent. CE), for a victor at the local Pythia (60, 2nd cent. CE:

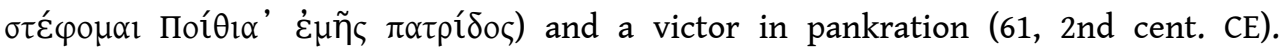
Herakleia Salbake: A relief is decorated with the representation of a male figure with

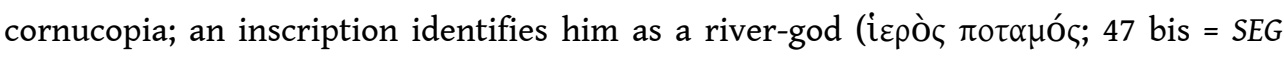
XXXI 933, 2nd cent. CE). Themisonion (?): A man dedicated to Theos Hypsistos the architrave and the threshold (of a shrine?) in fulfillment of a vow; the stone has the

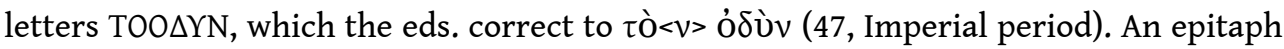

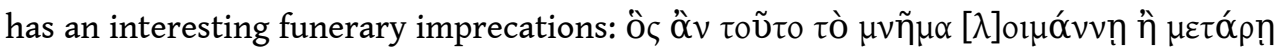

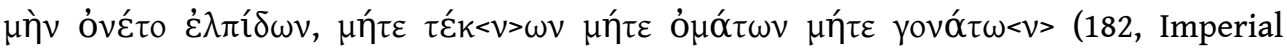
period) ['whoever pollutes or moves this memorial, let him have no luck in hopes, children, eyes, and knees']. The curse against the health of the knees is unattested

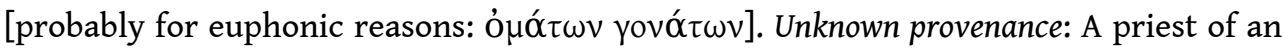
anonymous deity constructed and dedicated with his wife and children a temple and halls (23, 2nd cent. CE). A fragmentary inscription (46, Imperial period) seems to refer to a miraculous healing and to Asklepios. [Part of the text has been misread: 1. 2:

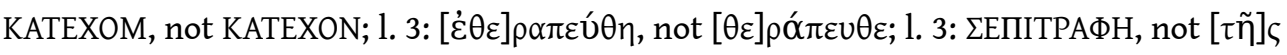

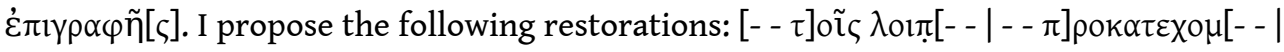

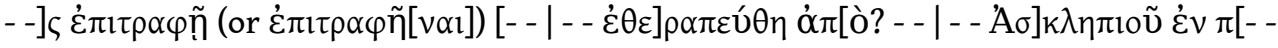

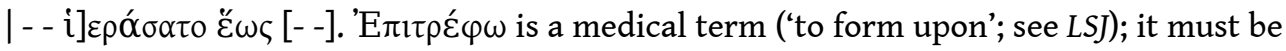




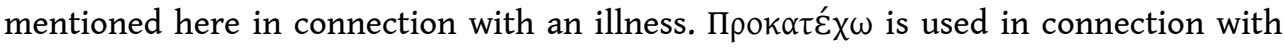

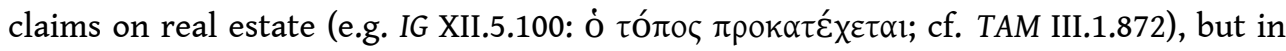
this context it is be used in connection with a disease, which 'had already gained possession of the body'. The text may be the narrative of a healing miracle or an honorific inscription for someone who served as priest (until his death?), after having been cured by the god.]. An epitaph contains an unusual funerary imprecation: 'whoever mutilates (the grave) shall be accountable in front of the one who gives light',

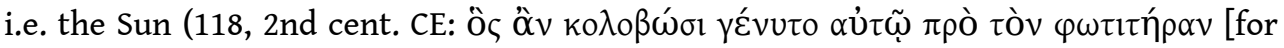

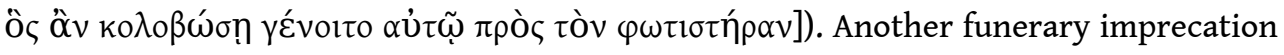
(184) is too fragmentary. The inscription with the invocation $\dot{\varepsilon} v o \rho \kappa i ́ \zeta o \mu[\alpha 1--] \Sigma 0[-]$ ПАNТ[- - ] is puzzling, since it is written on a small column with a Corinthian capital [probably invocation of a god (e.g. a form of $\pi \alpha v \tau[o \kappa \rho \alpha ́ \tau \omega \rho])$ rather than an invocation of the emperor].

91) J.-C. MORETTI, "Le coût et le financement des théâtres grecs", in L'argent, p. 147-187 [BE 2011, 294]: M. collects the mainly epigraphic evidence concerning the expenses connected with the existence of theaters in Greek cities (128 texts). The texts mainly concern the cost for the construction of theaters' facilities, infrastructure, and decoration. The various expenses were covered in different ways (public funds, sacred money, subscriptions, revenues from the leasing of the theater, donations by agonothetai, priests, kings, emperors, benefactors, and associations). The relevant material is summarized in three tables in an appendix. We single out the use of sacred money in Epidauros, Akraiphia, Bouthrotos, Delos ( $n^{\circ s} 13,22,34$ in the appendix).

92) P.M. NIGDELIS, “'Voluntary Associations' in Roman Thessalonike: In Search of Identity and Support in a Cosmopolitan Society", in L. NASRALLAH, C. BAKIRTZIS, S.J. FRIESEN (eds.), From Roman to Early Christian Thessalonike. Studies in Religion and Archaeology, Cambridge Ma., 2010, p. 13-47: N. studies the nature, membership, organization, and activities of 39 voluntary associations attested in Roman Thessalonike. Most associations (24) were cult associations; many of them were dedicated to Dionysos ( $\mu$

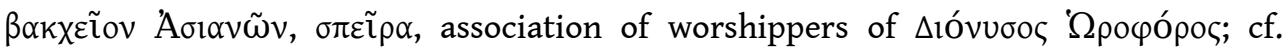

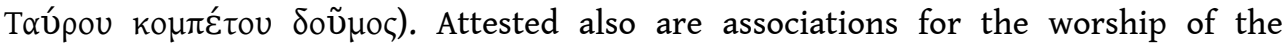

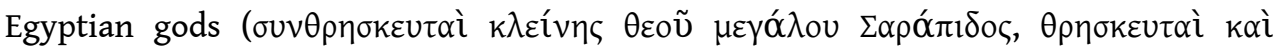

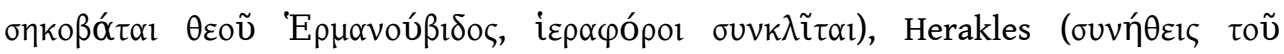

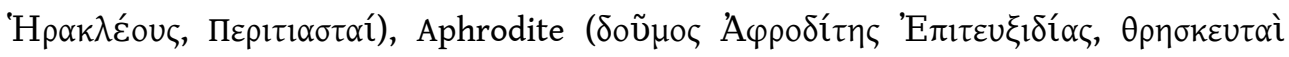

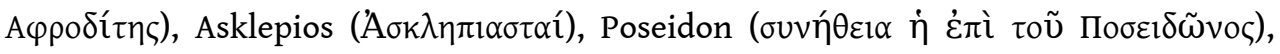

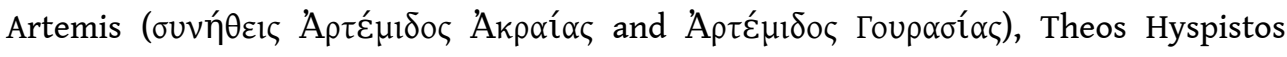

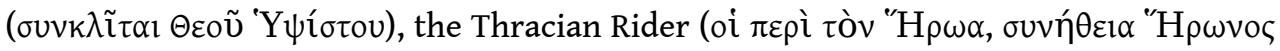

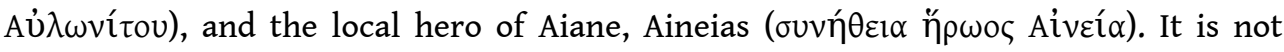

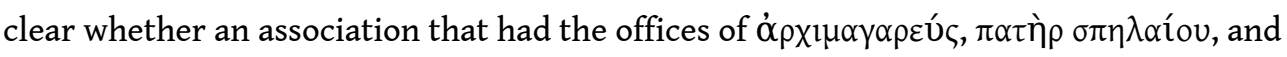

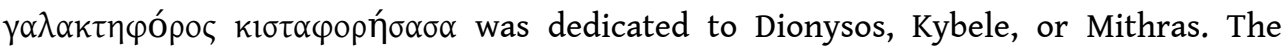
number of professional associations is smaller but many associations classified as religious were professional associations under the patronage of a particular god. The large number of associations in Thessalonike and the presence of many foreigners and descendants of immigrants among their members can be explained by the cosmopolitan character of the city and its importance for traffic. Membership was not limited to individuals of lower social status; the participation of women was very

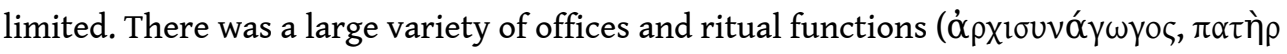




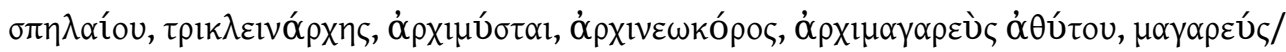

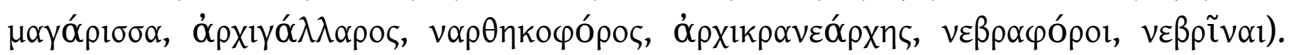
Common activities of the associations include the burial of their members, religious rituals, commemorative ceremonies, and feasts. Among the rituals, we single out the reenactment of Dionysiac myths in Dionysiac associations, the reenactment of a sacred

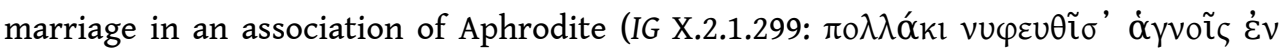

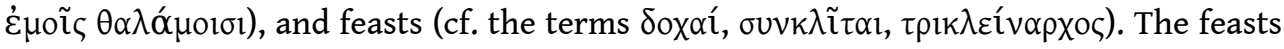
in connection with the cult of Zeus Dionysos Gongylos are of particular importance (IG X.2.1.259). An official donated a vineyard on condition that the association would continue performing ceremonial feasts on 19 Dystros (March), 13 Daisios (May), and 23

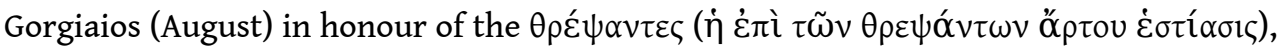
a group of deceased individuals, possibly the member's parents and relatives or the association's founders and patrons. These feasts were certainly connected with the funerary cult, as they seem to coincide with the Roman Parentalia (13-21 March) and the rosalia (13 Daisios, May), and possibly the Vinalia. For members of the middle and lower strata of society, participation in the life of an association offered an opportunity of conviviality, social integration, and collective identity.

93) C. PACE, "Aristofane a Rodi. Le Rane in un'iscrizione ellenistica", in Epigrammata -Susini, p. 299-330: An inscription from Rhodes (1st cent.; G. PUGLIESE CARRATELLI, Dionyso 8, 1940, p. 3-7), gives, under the heading 'Of Aristophanes', the text of Aristophanes', Frogs lines 454-459, part of the initiates' song. P. discusses in detail the phrase iहpòv $\varphi \varepsilon ́ \gamma \gamma o \zeta$, which should be seen in the context of initiatic rituals and the life of the initiates after death (Frogs 307-314). These verses were selected for epigraphic publication because of their religious meaning. According to Pugliese Carratelli, the inscription was set up in the context of a Dionysiac association but also because of the importance of the cult of Helios in Rhodes. But since the stone was found near the gymnasion, P. prefers the gymnasion, which possessed a library, as the most probable place for the stone's display. The explicit mention of Aristophanes shows that this quotation was selected for its literary value, as quotation of a 'Classic', in a city with a strong interest in theatrical performances. In the context of the gymnasion, the text served educational aims, both as a literary and a religious text. One cannot determine what the statuette supported by this base represented (Dionysos, Helios, or Aristophanes).

94) E. PACHoumi, "Resurrection of the Body in the Greek Magical Papyri", Numen 58 (2011), p. 729-740: Four spells in magical handbooks (PMG IV 1928-2005, 2006-2125, and 2145-2240; XIII 277-283) prescribe procedures involving the manipulation of the bodies of individuals who died prematurely or violently. A detailed study of these spells suggests that they imply more than the invocation of the spirits of the dead; they imply

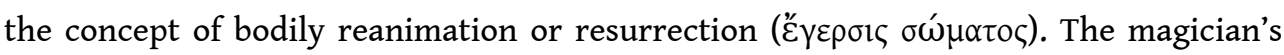

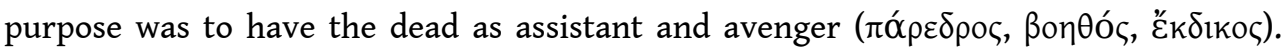
Examples of bodily resurrection are also known from literary sources (e.g. Lucan, Pharsalia 6.654-827; Lucian, Philopseudes 11, 13). The bodily resurrection connected with significant problems such as the duration of the resurrection and the relation between body and spirit.

95) O. PALAGIA, "The Grave Relief of Adea, Daughter of Cassander and Cynnana", in T. HOWE, J. REAMES (eds.), Macedonian Legacies: Studies in Ancient Macedonian History and Culture in Honor of Eugene N. Borza, Claremont, CA, 2009, p. 195-214 [SEG LIX 655]: P. 
presents a new interpretation for a grave relief and grave epigram from Beroia (I.Beroia 391). The relief represents a woman with chiton and petassos, identified as Hadea, daughter of Kassandros and Kynnana, the deceased woman to whom the monument was dedicated, and a girl holding a book roll and accompanied by Hermes Chthonios. On stylistic grounds, P. proposes a date in the late 4th cent. BCE (not late 3rd cent. BCE). She identifies the deceased Hadea as the infant and the woman with the petassos as a personification of Macedonia. The book roll is not a sign of education but the sacred book of an initiate into the Orphic mysteries: 'if Adea was too young for it [the initiation], her parents presumably were initiates and could therefore furnish her with a passport to the Underworld, held by her as a talisman' (p. 201). As regards prosopography, P. speculates that the parents of Hadea were Kynnana, the daughter of Amyntas IV and Kynnana, Alexander's sister, and Kassandros, the future king of Macedonia. [Kynnana, daughter of Amyntas, is not attested by any source. Personifications of regions are not attested in funerary reliefs. It is impossible that a man, who was not yet king of Macedonia, honored his infant girl with a funerary monument featuring a deified representation of Macedonia. There are no sources that attest that an infant could be accepted into the place of the underworld reserved for the initiates without personal initiation and only through the initiation of her parents. There is no doubt that the deceased Hadea is the woman over whom the name A $\delta \varepsilon^{\prime} \alpha$ has been inscribed, to whom the viewer's gaze is directed, and next to whom female attributes are represented (mirror, hat, fan, jewelry box)].

96) R. PARKER, "New Problems in Athenian Religion: The 'Sacred Law' from Aixone”, in Myths, Martyrs, and Modernity, p. 193-208: P. provides an English translation of the cult regulation from Aixone, summarizes its content, and discusses several problems of interpretation (ca. 400-375; SEG LIV 214; EBGR 2004, 256; 2010, 1-2) [cf. supra $\mathrm{n}^{\circ} 1$ ]. It was believed that Athenian demes had a limited number of priesthoods; according to the new text (and literary evidence), Aixone would have twelve or more. For this reason P. considers the possibility that the regulation was not that of the deme but of an unidentifiable genos based in Aixone. In that case, the priesthoods of the genos need not concern cults only in Aixone; the priests would have served cults scattered throughout Attica. The existence of pentekostyes rather favors the assumption that the document originates in the deme. In that case, the priests were recruited from and paid by the deme. The amounts mentioned in the text must represent an annual payment. As regards the identity of the Hagne Theos, the most likely candidate is Kore (cf. IGDS 38). It is remarkable that Kore was served by both a priest and a priestess (cf. Artemis Leukophryene, the gods of Andania, Artemis Hymnia); a parallel is provided by the joint activities of the priestess and the hierophant in the Eleusinian cult of Demeter and Kore. The regulation presents small variations with regard to sacrifices. A puzzling detail is that the sacrifice to Dionysos Anthios was sparser than the others; for this sacrifice the priestess did not receive compensation for the preparation of sacrificial cakes or for kindling; the latter detail may be connected with the association of Dionysos with $\omega \mu$ بо $\alpha \gamma i$ ' $\alpha$, 'raw meat eating' (cf. LSAM 48). What seems to be missing in this sacrifice is also the division of the rest of the meat, after the god's share had been placed on the altar, into equal portions with a double portion for the priestess; perhaps each participant cut off by chance a limb from the victim, as in an Arcadian ritual described by Pausanias (8.37.8). In an Appendix, P. discusses an honorific decree of a cult association of worshippers of the Agathe Theos for a woman from Kallatis (SEG LVI 203, 3rd cent.) [EBGR 2008, 155]. This goddess is only attested in a dedication from 
Piraeus (IG $\mathrm{II}^{2}$ 4589). This inscription was found close to a spot that has yielded inscriptions pertaining to the cult of Kalliste, whom Pausanias identified with Artemis (1.29.2). Agathe Thea and Kalliste may be epithets describing Artemis' nature. The

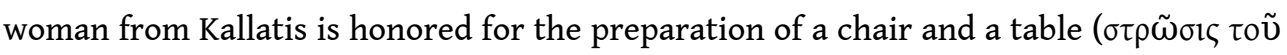

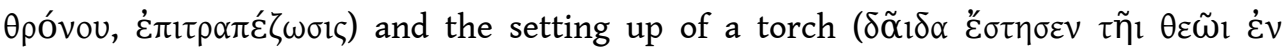

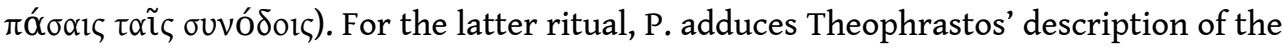
chatterbox (Characters 3.3), who set up a huge torch during the mysteries. The same ritual is also attested as an honor paid to the statue of Ariarathes by the Dionysiac artists, who were to crown the statue, burn incense, and set up a torch (IG $\mathrm{II}^{2} 1330$, ca. $130 \mathrm{BCE}$ ). Unfortunately, it is not clear what the ritual entailed and how it was related to the nature of the Agathe Theos. [Both in the Eleusinian context and in the context of the meetings of the association it seems that we are dealing with nocturnal ceremonies; they make sense in connection with both the Eleusinian goddesses and with Artemis. It is very probable that the context also of the rituals for Ariarathes' statue is that of nocturnal celebrations of the Dionysiac artists].

97) R. PARKER, “The Thessalian Olympia”, ZPE 177 (2011), p. 111-118: A Thessalian decree from Aigai in Asia Minor attests the celebration of the festival Olympia in Thessaly [EBGR 2009, 98; SEG LIX 1406; BE 2012, 253]. Because of the mention of 'the Thessalians', i.e. a Thessalian federation, P. dates the decree to ca. $280 \mathrm{BCE}$, before Antigonos Gonatas gained control over Thessaly. The sanctuary of Zeus Olympios (Olympion) cannot have been a sanctuary on top of Mt. Olympos but probably a sanctuary on Larisean territory. The Aiolians, Koans, and Magnesians were honored because they performed a rite and a sacrifice to Olympian Zeus and the hero Thettalos. This cannot have taken place in a place in Asia Minor but at the Thessalian Olympia. This corresponds to the custom of Hellenistic cities and koina to invite to festivals cities and koina with whom they were connected with kinship [see also the observations of J.-C. DECOURT, B. HELLY, BE 2012, 253].

274 98) I. PATERA, "Changes and Arrangements in a Traditional Cult: The Case of the Eleusinian Rituals", in RitualDynamics in the Ancient Mediterranean, p.119-137: P. presents a panorama of changes in ritual practices in a very traditional and conservative cult: the cult of Demeter and Kore in Eleusis (5th cent. BCE - 3rd cent. CE). Through a study of the epigraphic and archaeological evidence she shows that changes or arrangements were decided at critical moments in order to overcome temporary difficulties. Changes are attested both in the ritual norms and in the actual performance of the rituals. P. examines the following developments: the extension of participation, temporary changes in the calendar of initiation in favor of monarchs (I.Eleusis 483), the introduction of Asklepios' cult (IG II ${ }^{2} 4960$ ), the restoration of ancestral sacrifices (IG II $^{2}$ 1338), temporary interruptions of the cult because of wars,

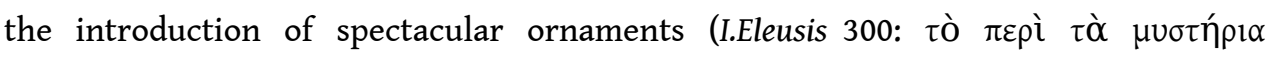

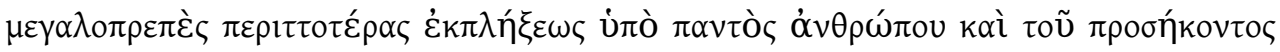

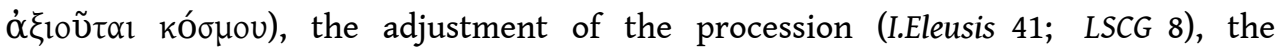
administration of the cult (truce and finances: IG I $I^{3} 6=$ I.Eleusis $19=$ LSCG Suppl. 3; firstfruits offerings: IG $\mathrm{I}^{3} 78$ = I.Eleusis 28; aparche: I.Eleusis 142 = LSCG Suppl. 13; hieropoioi and epistatai: IG $\mathrm{I}^{3} 32$ and 391), conflicts concerning the jurisdiction over the sanctuary, and changes regarding pyres, the use of kernoi and plemochoai, the Sacred House, and the eschatological aspects of the mysteries. The factors that led to changes include Athens' imperial aspirations, its political subordination to ambitious statesmen and monarchs, 
the opposition between the sacred officials of Eleusis and the Athenian state, the introduction of new cults, wars, and the personal initiatives of individuals.

99) S. PERROT, "Récompenses et rémunérations des musiciens à Delphes", in L'argent dans les concours,p. 283-299: P. studies the various expenses and material rewards of musicians in Delphi, adducing inscriptions that refer to the activities of musicians during contests (Pythia, Soteria), during recitals (F.Delphes III.4.361 = CID IV 49), and in the regular cult service. P. also collects information for the organization of musicians in groups and the diverse attitudes towards money rewards. An interesting phenomenon that reveals the reservation towards money awards is the erasure of passages recording the payment of money in some inscriptions (F.Delphes III.1.249; Syll. ${ }^{3} 689,737$ ).

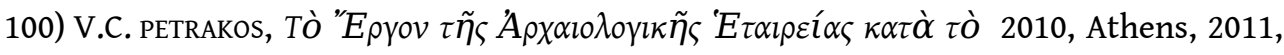
22. During excavations of a building of religious function (temple?) in Thouria (Messenia), a treasure-box was discovered. An inscription gives the names of two hierothytai and three damiourgoi, under whom the treasure-box was made, as well as the name of the architect Theodoros (late 4th/early 3rd cent.).

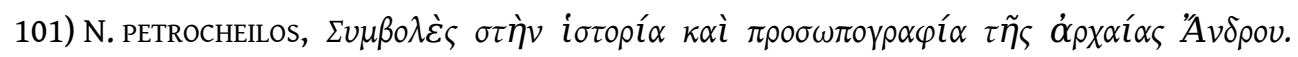

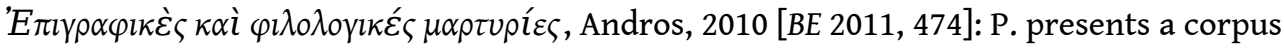
of the 219 inscriptions hitherto known from the island (inedita are marked with an asterisk). Cult regulations: For a rock-cut regulation concerning a festival on the 14th of

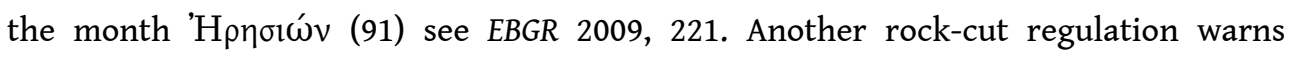
women not to defecate in the area of a sanctuary (96). Festivals and rituals: A document provides rules for the organization of the Andrian theoria sent to Delphi (CID I $7=1$, ca. 425). An Andrian decree concerns the acceptance of the Soteria [see EBGR 2008, 124]. An honorific decree for a gymnasiarchos (9, ca. 175-159) provides information on the celebrations that took place in the gymnasion (procession and sacrifice on the birthday of Eumenes II; sacrifices to Asklepios, Hygieia, Hermes, and Herakles). An honorific decree for a priest mentions a banquet to which he invited not only citizens but also freedmen and foreigners (18, 1st cent.) [cf. EBGR 2010, 182]. Cult officials: Inscriptions mention the daughter of a high priest (52), a priest of Zeus Ma[--] (*101), priests (55, 56), a priestess (58), and a priestess of Dionysos (121). Ruler cult: Numerous altars were dedicated to Hadrian $\left(74-80,{ }^{*} 81-{ }^{*} 83,84\right)$; a building (macellum?) was dedicated to Antoninus Pius, Lucius Verus, and Faustina (85). Dedications to: Artemis (118), Demeter and Kore (98), Dionysos Megas (119), Eileithyia (97), Herakles (90; a votive relief), Hermes (100, dedication of the doors and side-doors of a building by the agoranomoi), Homonoia (*110), Meter Theon (*103) [see EBGR 2010, 149], Mithras (124, by a praetorian soldier), Nemesis (104, an altar), Nemesis and Adrasteia (108), the Nymphs

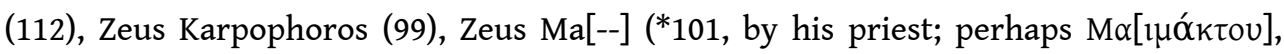

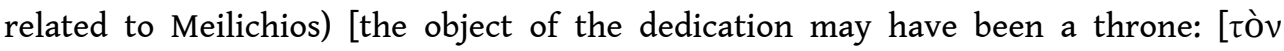
$\theta$ ?]póvov], the Katachthonioi Theoi (114), an unknown goddess (109), and unknown deities $\left(111,115,116,{ }^{*} 122\right.$ ?). The cult of the Egyptian gods is attested through the famous hymn to Isis (128). $\mathrm{n}^{\circ} 113$ mentions statues of Hestia Boulaia and Apollo Patroios (restored). A relief that mentions Sosineos is identified by P. as a representation of Poseidon (95: $\Sigma \omega \sigma i ́ v \varepsilon \omega$, 4th cent.); the cult of Poseidon Sosineos is attested in Pantikapaion (CIRB 30). [The text seems to be later (3rd cent.). To judge from the photo, the relief does not represent Poseidon but a reclining man in a funerary banquet scene. Sosineos is attested as a personal name (LGPN II, s.v.). The inscription more likely refers to a deceased man than to a hero; the cult of $\Sigma \omega \sigma i ́ v \varepsilon \omega \varsigma$ (a hero?) is 
attested in the sacrificial calendar of Thorikos (SEG XXXIII $147=$ NGSL 1 lines 50)]. A text is restored as a dedication to Heros Prophylax (116 = IG XII Suppl. 269: [n้ $\rho \omega I]$

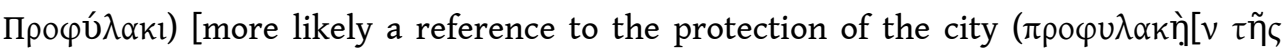
$\pi$ ó $\lambda \varepsilon \omega$ c; cf. I.Histriae 15 l. 50 and 55; IG XII.4.99 line 27]. There is a votive relief with the Thracian Rider $(125=$ CIG 2054) [but not from Andros. This is a pierre errante from Thrace or Macedonia (see SEG XXXVI 769)]. Sanctuaries: The boundaries of sanctuaries were marked through rock-cut boundary markers of the sanctuaries of Zeus Meilichios

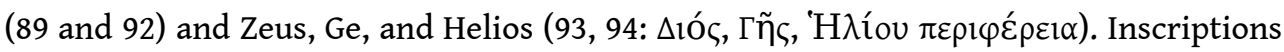
refer to the dedication of a building as aparche (only restored: $120=$ IG XII.5.736), the restoration of a building by a priestess of Dionysos (1st cent. AD; 121), and repairs in a temple and a pronaos (123, 2nd cent. CE). Zagora: The graffiti on vases from Zagora include dedications to Athena Polias (199, late 6th cent.) and Herakles (201, late 5th cent.).

102) G. PETZL, "Keine Szepter auf Gräbern”, ZPE 177 (2011), p. 123-126: Both 'confession inscriptions' and grave inscriptions attest to the erection of scepters, as symbols of divine power, in order to prevent crimes (e.g. TAM V.1.159, 160, 167a, 172; SEG XXVIII 917; XXXII 1222; XXXIII 1029-1030; XXXIV 1231; XL 1100; LIII 1344); those who ignored them were threated with divine wrath. Two new grave inscriptions attest this practice (EBGR 2009, 5; SEG LVIII 1359). The scepters were not erected near the graves but in sanctuaries, where the imprecations took place.

103) P. PILHofer, Neues aus der Welt der frühen Christen, Stuttgart, 2011: P.'s collection of studies on subjects relating to early Christianity includes the discussion of several inscriptions. On p. 18-22, he discusses the similarity in expression between New Testament sources and polytheistic inscriptions as regards divine instructions given in

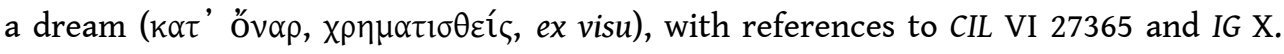
2.1.67 (ph.). In a discussion of the addresses of Paul's Epistle to the Galatians, P. studies the origin of the priests of the emperor cult in Ankyra (p.111-125: text; German translation); he doubts S. Mitchell's view that most if not all the priests were Celts or had strong Celtic connections.

104) J.-L. PoDvin, Luminaire et cultes isiaques, Montagnac, 2011: P. presents a detailed study of lamps with Isiac iconographic themes and discusses the use of lamps in Isiac rituals. The subjects discussed include the types of lamps, their iconography (representations of Isis, Sarapis, and other Egyptian gods and groups of gods, lamps in the form of a ship and a mummy), the production and circulation of lamps, the domestic, public, and religious places in which they are discovered, and the use of

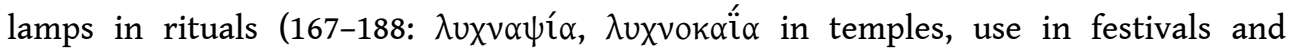
processions, initiation ceremonies, funerary cult, and pilgrimages, dedication of lamps). For the study of the rituals, P. adduces the epigraphic sources; many lamps were inscribed with acclamations.

105) A.H. RASmussen, "A Note on the Appointment of Priests in Attic Gene", ZPE 176 (2011), p. 120-125 [BE 2012, 161]: Responding to the study of J.H. Blok and S.D. Lambert on the priests of Athenian gene (EBGR 2009, 23), R. discusses the priesthoods of Athena Polias and Poseidon Erechtheus. He argues that Ps.-Plutarch, Life of Lykourgos (842f-843c) does not prove that the priesthood of Poseidon Erechtheus was monopolized by a special family branch, that of Lykourgos. Similarly, an inscription commemorating the priestess Lysimache (IG $\mathrm{II}^{2} 3455$ ) cannot be regarded as proof that a particular branch of the Eteoboutadai, coming from the deme Bate, monopolized the 
priesthood of Athena Polias. The evidence concerning the Salaminioi shows that priests were appointed by lot from among all the members of a genos.

106) S. REMIJSEN, “The So-Called 'Crown-Games': Terminology and Historical Context of the Ancient Categories for Agones", ZPE 177 (2011), p. 97-109 [BE 2012, 131]: R. discusses the chronological development of the various designations of agonistic festivals as

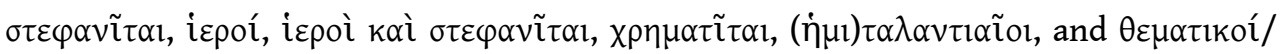
$\theta \varepsilon \mu \alpha \tau \tilde{\imath} \tau \alpha$. Her main conclusions are that one should distinguish between the descriptive categories of 'crown-games' and 'prize-games' found in literary sources, and the technical categories of festivals attested in inscriptions. The modern dichotomy between 'crown-games' and 'prize-games' does not correspond to an ancient contrast

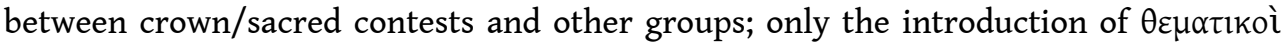
$\dot{\alpha} \gamma \tilde{\omega} v \varepsilon \zeta$ in the 2nd and 3rd cent. created a new distinct category of contests, for which funds were laid down for a regular organization. The award of a material prize was never a criterion for the technical categorization of festivals in inscriptions; a technical categorization developed in the mid-3rd cent. and was subject to further evolution. The

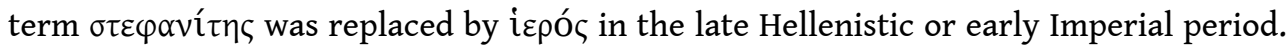
In the Hellenistic period each city decided for itself which contests were stephanitic and which were not, whereas in the Imperial period the emperor decided about the grant of the title 'sacred' to an agon.

107) G.H. RENBERG, W.S. BUBELIS, "The Epistolary Rhetoric of Zoilos of Aspendos and the Early Cult of Sarapis: Re-Reading P.Cair.Zen. I 59034", ZPE 177 (2011), p. 169-200: The letter of Zenon to the dioiketes Apollonios (P.Cair.Zen. I 59034, 257 BCE) is one of our most important sources for the promotion of an ancient cult, in this case the cult of Sarapis. The authors present a new edition and translation of the letter and examine in great detail the strategies used by Zenon in order to gain Apollonios' support for the construction of a sanctuary for Sarapis, at which members of the Greek and Macedonian community could worship the Hellenized version of Sarapis in his own right. Zenon's dream, in which Sarapis gave him instructions, can be placed in a contemporary religious context of epiphanic dreams; it did not require incubation.

108) J. REYNOLDS, "A New Inscription from Ptolemais in Libya", in Onomatologos, p. 119-

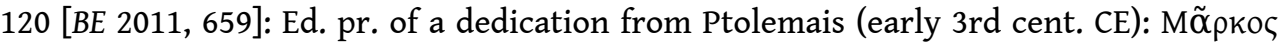

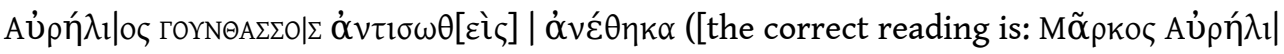

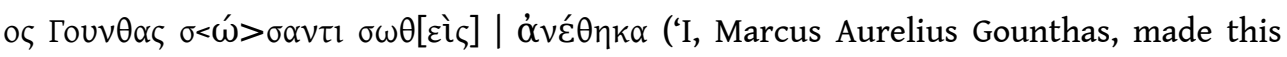
dedication to the [god] who saved me, after I have been saved'); see É. PERRINSAMINADAYAR, An.Ép. 2010, 1764].

109) K. RIGSBY, “The New Lamella from Pherae", RhM 154 (2011), p. 61-67: R. discusses the new metrical lamella from Pherai (SEG LV 612; EBGR 2005, 117; 2009, 20, 58), which has been associated with Dionysiac-Orphic initiation. He proposes to restore the last

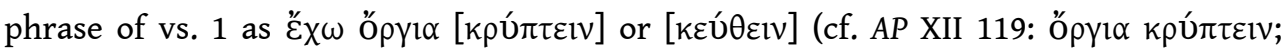

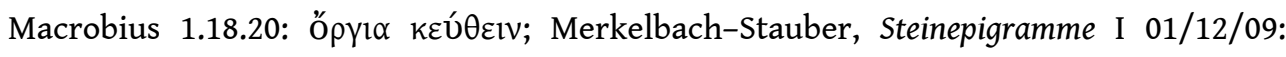

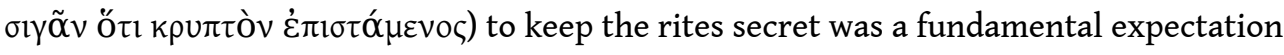
for an initiate. This is why the text does not clearly identify the cult into which the bearer was initiated. The text states: 'send me to the congregations of the initiates. I can keep the rites secret, the ceremonies of Demeter Chthonia and the Mountain Mother'. In this restoration, which eliminates a reference to Dionysos, a living initiate identified himself before his ceremonious entry to the community of initiates (cf. Plautus, Miles Gloriosus 1016, for a reference to a signum Baccharum); the speaker is not a 
dead initiate identifying himself to the guardians of the underworld. The private cult in question, dedicated to the syncretic figure of Demeter and Meter Oreia, drew its ideas and utterances from diverse celebratory precedents.

110) I. RUTHERFORD, "The Koan-Delian Ritual Complex: Apollo and Theoria in a Sacred Law from Kos", in L. ATHANASSAKI, R.P. MARTIN, J.F. MILleR (eds.), Apolline Politics and Poetics, Athens, 2009, p. 655-687: R. discusses in detail a fragmentary cult regulation from Kos (LSCG 156; Insc.Cos ED 55, 4th cent.) [IG XII.4.1332], which refers to the cult of Apollo Delios, whose worship is well attested on Kos (PH 125; Iscr.Cos ED 45; LSCG 155 D). The text refers to sacrifices, those who were to perform them, the purpose, the offering, the prerogatives of the priest, and, in some cases, prohibitions against removal of meat ( $\dot{\varepsilon} \xi \alpha \gamma \omega \gamma \eta$ ) from Kos (not from the venue of the sacrifice). R. distinguishes six entries: 1) a sacrifice to Apollo (Dalios?); 2) a sacrifice for good omens and fair winds for the theoroi sent to Apollo Delios; 3) an undetermined sacrifice; 4) a sacrifice offered by the Knidians; 5) an offering on the occasion of theoriai sent to Delphi; 6) a sacrifice on behalf of the Amphiareidai. Given that the theoriai sent to Delos represented the Koan state, $R$. infers that the festival took place in the main polis, not at the Dalion presumably located in Halasarna. The reference to Knidians and other groups suggests that there was an interstate network or amphictyony that sent offerings to a common sanctuary; possible members of such an amphictyony would include Koan demes (Isthmos, Halasarna), Kalymnos, Rhodes, Kasos, Nisyros, and Telos. The main activity of such an amphictyony was the sending of theoriai to Delos and Delphi (or a single theoria sent to both sanctuaries). The deme of Isthmos had a special place in this festival and in the theoria;possibly it had been the primary point of contacts with Delos. The embassy was led by the Amphiareidai and included a group of nine girls (’’ $\gamma \rho \varepsilon \tau \alpha$ ) $)$, possibly representing nine subdivisions of the city, representatives of the Pamphyloi, and non-Koans. The decree was probably passed on the occasion of the Koan synoecism of $366 \mathrm{BCE}$ and articulated the new political unity.

111) P. SÄNGER, "Neue Inscriften aus der nördlichen Außenmauer des ephesischen Theaters", Tyche 26 (2011), p. 235-246 [BE 2012, 23]: Ed. pr. of a dedication of a statue of Hygieia (Ephesos, late 2nd/early 3rd cent.).

112) C. SÁNChez natalías, “The Bologna defixio(nes) Revisited”, ZPE 179 (2011), p. 201217: S. presents new critical editions of two Latin defixiones acquired by the Museo Archaeologico Civico di Bologna and published by A. Olivieri in 1899 ("Tavolette plumbee bolognesi di defixiones", Studi Italiani di Filologia Classica 7 [1899], p. 193-198), considered lost until 2009. The author discusses in detail the formulas used by the defigens. We present the translations of the two texts (4th/5th cent.): 1) 'Porcello. Porcello the veterinarian. Porcello the physician. The veterinarian. Destroy his entire body, his head, teeth, eyes --. Let Porcello and his wife, Maurilla, be --. May all Porcello's body, limbs, entrails -- disintegrate, languish, and collapse. Porcello the veterinarian and Maurilla his wife. Porcello. Porcello. Veterinarian (?) Porcello the veterinarian. Destroy, crush, kill, strangle Porcello and his wife Maurilla. Their soul, heart, buttocks, liver --'. 2) '-- tertian, quartan fevers -- pallor, cold, disease -- Porcello the veterinarian -- fire'.

113) H.G. SARADI, D. eliopoulos, "Late Paganism and Christianisation in Greece", in Late Antique Paganism, p. 263-309: The authors summarize the archaeological and epigraphic evidence for the continuation of the traditional religious practices in Late Antique Greece, especially in Athens, Eleusis, and Phyla (evidence for taurobolium: IG II $^{2} 4841$ - 
4842), Corinth, Argos, Delphi, and Olympia. They also discuss the use of 'pagan' statuary in Christian contexts. They briefly discuss the epitaph of Nikandros in Edessa (Feisseil, Recueil $\mathrm{n}^{\circ}$ 5), a convert to Christianity; the epitaph refers to resurrection and baptism but also uses the 'pagan' metaphor of the ascent of the soul to the ethereal aeons'

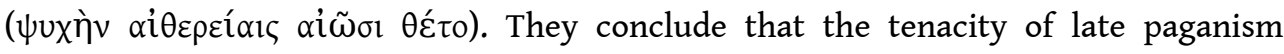
differed from one site to another. Often, the causes of the destruction of temples and statues cannot be determined with certainty. The ritual activity continued into the late 4 th cent. The late 4 th and early 5 th cent. were periods of struggle. Christian churches were spreading from the mid-5th cent.

114) M. SARTRE, Inscriptions grecques et latines de la Syrie. Tome XIII. Fascicule 2. Bostra (Supplément) et la Plaine de la Nuqrah, Beyrouth, 2011 (avec la collaboration d'A. SARTEFAURIAT) [BE 2012, 480-483]: The new volume of this corpus presents addenda to the incriptions of Bostra and the plain of Nuqrah. Bostra: Dedications are addressed to

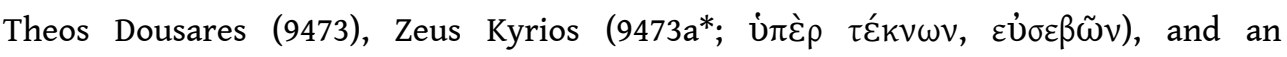

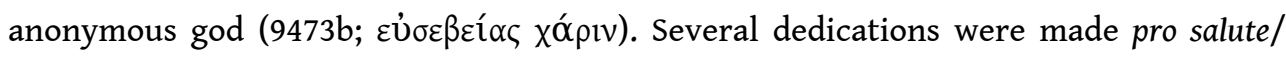

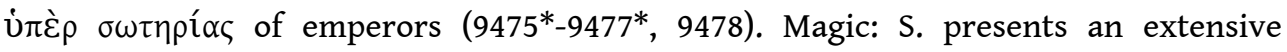
commentary on a defixio included in EBGR 1991, 128. Deir: A dedication to the Tyche of a

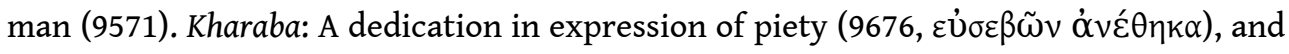
a dedication to Zeus on behalf of emperor Gordian (9677a*). Al-Ghariyyeh al-Sharqiyyeh: A dedication for the god of Ameros (9768a). An inscription records the acclamation $\varepsilon \tilde{i} \varsigma$

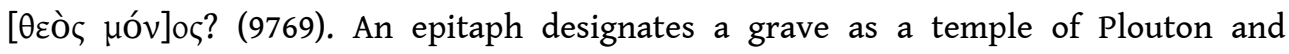

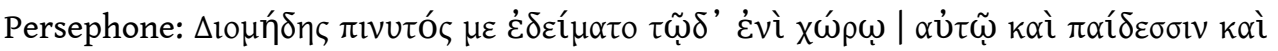

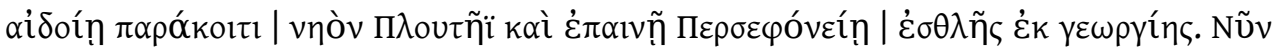

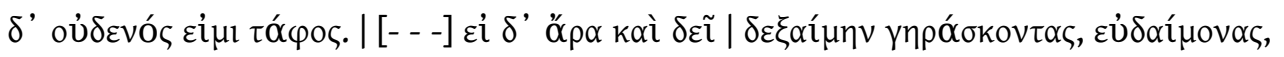
$\tau \varepsilon \kappa v \omega ́ \sigma \alpha \nu \tau \alpha \varsigma$ ('l'avisé Diomèdès m'a construit en ce lieu pour lui-même, ses enfants et sa vénérable épouse, temple pour Pluton et la redoutable Perséphone, grâce à la riche agriculture. Maintenant, je ne suis le tombeau de personne [---] Mais si donc il le faut, puissé-je les recevoir âgés, heureux, et pourvus d'enfants'). The same text was inscribed a second time, probably for a different grave (9774). Another epitaph (9775) compares

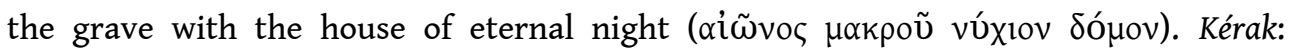

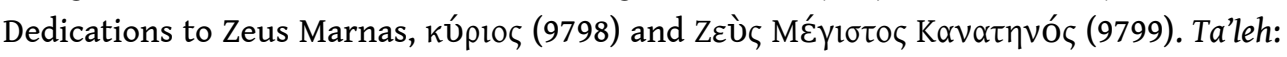

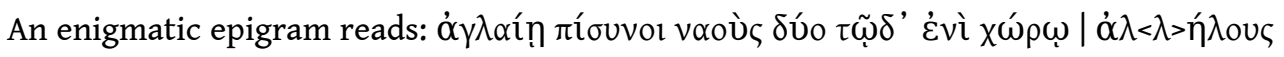

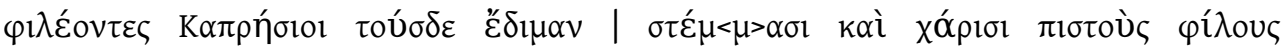

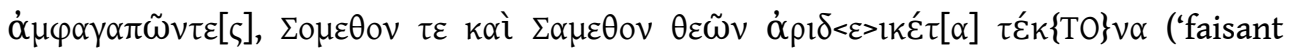
confiance à la beauté, les Kaprèsioi qui s'aiment les uns les autres ont construit ces deux sanctuaires en ce lieu-ci, entourant de leur affection par des couronnes et des marques d'égard leurs amis fidèles, Somethos et Samethos, remarquables enfants des dieux'). Without entirely excluding a Christian context, S. wonders why two associated temples were dedicated to Somethos and Samethos, designated as 'sons of the gods' (9822*). Al-Tireh: Three commemorative inscriptions (with the formula $\mu \nu \eta \sigma \theta \tilde{n}$ ) record dedications in a sanctuary (9842a-c). Two men dedicated a $\pi \tilde{\omega} \lambda$ oৎ (a statuette? or an

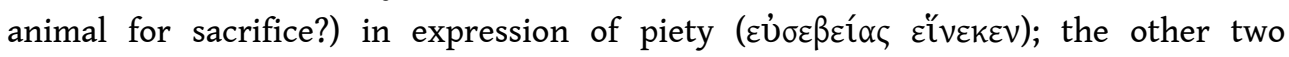
dedications record the construction of lintels ( $\dot{\tilde{z}} \varepsilon \dot{\varepsilon} \rho v \rho \alpha)$. Saama': A man constructed a

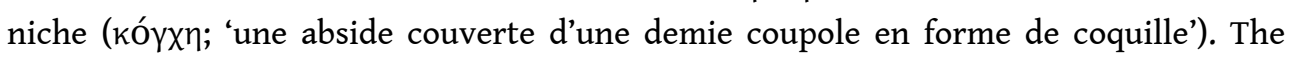

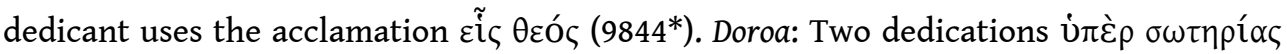
of emperors $\left(9847,9848^{*}\right)$. Mleihat Sharqiyyeh: The acclamation $\varepsilon \tilde{i} \varsigma \theta \varepsilon$ $\theta$ ک is used in an epitaph (9862). Sawara: A building inscription records the restoration and construction 
of 'the Great Fortune of the village', i.e. of a temple of Tyche (9882). Another inscription

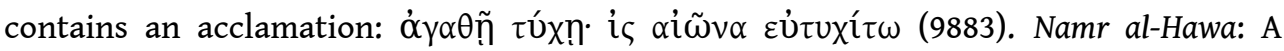

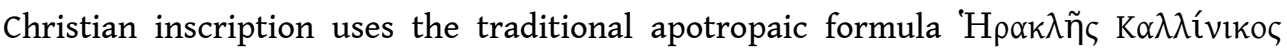

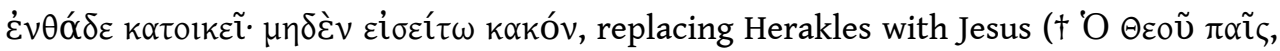

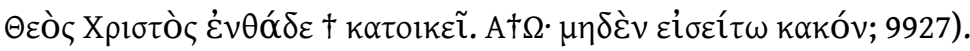

115) H. sCHWARZER, Altertümer von Pergamon XV. Die Stadtgrabung. Teil 4. Das Gebäude mit dem Podiensaal in der Stadtgrabung von Pergamon. Studien zu sakralen Banketträumen mit Liegepodien in der Antike, Berlin, 2008: The publication of the 'Podiensaalgebäude' in Pergamon, which was used for ritual banquets of a Dionysiac association of boukoloi (p. 92-103), includes several inscriptions (p. 235-237 and 243): a small fragment with a form of the word $\mu v \sigma \tau n ́ p l \alpha ~(S 12,2$ nd cent. CE; SEG LVIII 1409); a dedication to Dionysos (S13, 2nd/1st cent.; SEG LVIII 1391); dedications to Dionysos Kathegemon (S18, late 1st cent.; SEG LVIII 1392) and Augustus (S19; SEG LVIII 1384) by an archiboukolos; a dedication to the Korybantes (S20, Imperial period; SEG LIX 1396); an altar dedicated to Attalos Soter (Attalos I, late 3rd cent.; SEG LVIII 1382); a small altar dedicated to Hera (S17, 2nd cent. CE; SEG LVIII 1394); a dedication to Hadrian Olympios (U3; SEG LVIII 1385). In a discussion of the association of boukoloi, S. republishes the relevant inscriptions (98-102: I.Pergamon 222, 485-488).

116) C.-G. SCHWENTZEL, "Théocraties et rois clients: Antiochos Ier de Commagène et Hérode le Grand", DHA 36/1 (2010), p. 119-136: Both Antiochos I of Kommagene, with his cult reforms, and Herod the Great in Judaea promoted the idea of a divine origin of their rule as a unifying factor in their realms. Despite the differences, which originated in the different religious tradition of the two kingdoms, there are similarities, especially in the extensive building programs. S. examines theocratic aspects in the cult reforms of Antiochos and the relevant inscriptions (esp. OGIS 383): the introduction of the ruler's cult, his presentation as a transmitter of divine words and divine norms, the consecration of his image, the appointment of priests belonging to the aristocracy, and the creation of a network of sanctuaries (hierothesia) in his kingdom.

117) G. STAAB, "Das Grabepigramm des Euelpistos aus Tomi”, ZPE 179 (2011), p. 97-102: See supra $\mathrm{n}^{\circ} 8$.

118) E. STAVRIANopoulou, "'Promises of Continuity: The Role of Tradition in the Forming of Rituals in Ancient Greece", in Ritual Dynamics in the Ancient Mediterranean,p. 85-103: S. examines how 'tradition' was used as an argument in favour of or against transformations in ritual practice by looking at the codification of ritual practice in stone. She examines two cases: the speech of Lysias Against Nikomachos (30), concerning the addition of sacrifices in the Athenian sacrificial calendar, and the Athenian decree on the renewal of the Thargelia (LSCG Suppl. 14, 129/8 BCE). As her analysis shows, the latter text provides an instructive example of the preservation of traditional ritual actions and, at the same time, of their alteration. The 'original' status of the festival, celebrated by phratries, is displayed vaguely through such expressions as 'norm of the forefathers', 'custom of the Athenian demos', and 'ancestral tradition'. In the past, Apollo, reinterpreted as a 'god of the fatherland and of the forefathers', had prescribed the resumption of his cult and the performance of sacrifices. These stipulations 'stated in the earlier decrees' were now improved by means of the new decree. Great emphasis is now given to the organisation and arrangement of the festivities (processions, prayers, sacrifices). All these changes come under the heading of 'maintenance of the ancestral customs and norms'. 
119) D. SummA, Inscriptiones Graecae Graeciae Septentrionalis. Pars I. Inscriptiones Phocidis, Locridis, Aetoliae, Acarnaniae, Insularum Maris Ionii. Editio altera. Fasciculus V. Inscriptiones Locridis Orientalis, Berlin, 2011 [BE 2012, 245]: The corpus of the inscriptions of Eastern Lokris contains several inscriptions of religious interest (new texts are marked with an asterisk). Martino: A dedication (of an honorific statue?) to the gods (1843 = IG VII 4166). Halai: A catalogue of the individuals responsible for a festival (1864, late 3rd cent.) mentions the choregoi of comedies, the weavers of robes, probably for the statue of

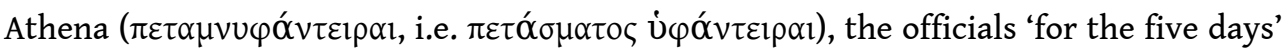

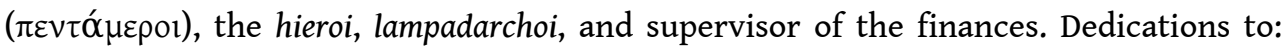
Athena (1867-1870, 1890*, 1896*) and the gods (1871). Kyrtona: Two men dedicated to Demeter and Kore the statue of their mother after she had served as a priestess (1907, 2nd cent.). Opous: The Isthmian and Nemean branch of the association of the Dionysiac artists whose seat was in Opous honored Soteles for his support and his piety towards the gods. Soteles and his wife had given an endowment to Apollo, Hermes, and the

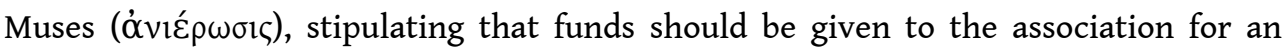
annual sacrifice to these gods (1918, 2nd cent.). A small fragment contains a copy of the dossier of documents concerning the conviction of officialsfor financial mismanagement of Apollo's sanctuary in Delphi (CID IV 119 A-H; 1921, ca. 117 BCE) [see EBGR 2010, 186]. Dedications to: Zeus Patroos and Athena (1926, ca. 350 BCE), Artemis Ennodia (1929, 1st cent; by her priest), Hermes and Herakles (1936-1937, 1st cent. CE; honorific statues of a gymnasiarchos and benefactor), and the gods (honorific statues: 1935, 1st cent.; 1940, Imperial period). An altar was set up for sacrifices to Zeus Patroios and Athena, and Zeus Soter and Athena (1927, 4th cent.) [for such altars see EBGR 2010, 144]. Theopompos dedicated images of Dionysos, Apollo and other gods (1928, 4th cent.). Cn. Calpurnius Helix, priest of Augustus and agonothetes of the trieteric Dionysia dedicated a fountain to the Populus Romanus, Augustus, and the Demos (1930, reign of Augustus). L. Allius Tauros made a donation to the gymnasia for the Gens Augustorum ( $\ulcorner\varepsilon ́ v \varepsilon l ~ \Sigma \varepsilon \beta \alpha \sigma \tau \tilde{\omega} v)$ and the city (1931, 1st cent. CE). Kynos: A vase dedicated to the gods (?, 1996, 5th cent.). Alope: A dedication to the gods (2003*, 4th cent.). Naryx: A letter of Hadrian refers to the local mythical heroes (2018, 138 CE; see EBGR 2006, 67). Komnina: A dedication to Eileithyia (2029, Hellenistic). Anavra: A sacred manumission in the form of dedication to Sarapis $\left(2030^{*}\right.$, 2nd cent.). Unknown provenance: An inscribed wheel dedicated by a pediarches to Apollo (2042, 6th cent., from Galaxidi?).

120) D. summa, "Ricerche sulla vita teatrale e il suo finanziamento in Locride", in L'argent dans les concours, p. 107-125 [BE 2011, 309]: The evidence for musical performances in western Lokris is almost non-existent (the poetess Aristodama: IG IX ${ }^{2}$. 1.3.740), although there is some evidence for the cult of Dionysos (Naupaktos: Dionysia; Physkos: month Dionysios; Dionysiac thiasos: IG IX ${ }^{2} .1 .3 .624,670$ ). The office of the agonothetes in Physkos is related with the festival Rhieia or, more probably, with the federal festival of Athena Ilias (cf. IG IX ${ }^{2}$.1.3.688). In eastern Lokris, the evidence is more abundant. In addition to a theater in Naryx, where the festival Aianteia is attested (cf. IG IX ${ }^{2}$.1.3.706; IG IV ${ }^{2}$.1.629), there is evidence for numerous victors in musical and dramatic contests originating mainly from Opous. Dramatic festivals existed in Halai and Opous. With regard to the funding of contests, the Aianteia were publicly funded, whereas private sponsors are attested for a contest of comedies in Halai (2 choregoi) and for the trieteric Dionysia in Opous (an agonothetes). A decree of the Dionysiac artists in Opous honors a local benefactor (IG IX 2 1.5.1918). 
121) P. talloen, L. vercauteren, “The Fate of Temples in Late Antique Anatolia”, in Late Antique Paganism, p. 347-387: The authors discuss the primarily archaeological evidence for the very diverse fate of temples in Late Antique Asia Minor: decay because of lack of financial backing and deteriorating legal status, violent destruction, use as quarries for building projects, secular and religious conversion. The rather scanty evidence for religious violence includes a 2nd-cent. CE dedicatory inscription from the sanctuary of Demeter and Kore in Sagalassos (Sagalassos IV, Leuven, 1997, p. 147 and 149), which was violently removed and re-used to cover a sewer; the Christian acclamation 'One God' was carved on the mutilated relief (p. 352f.).

122) P. themelis, "Die Agora von Messene", in H. frielinghaus, J. StroszeK (eds.), Neue Forschungen zu griechischen Städten und Heiligtümern. Festschrift für Burkhardt Wesenberg zum 65. Geburtstag, Möhnesee, 2010, p. 105-125: T. summarizes the results of excavations in the agora of Messene. Literary sources, archaeological finds and inscriptions attest the existence of sanctuaries of Poseidon, Zeus Soter, Aphrodite, and Meter Theon. T. presents already published dedications to Aphrodite, Apollo Agyieus, Megale Meter, Poseidon, Zeus, Zeus Soter, Zeus Kasios, inscribed roof tiles with the name of Zeus, and a boundary marker of the sanctuary of Aphrodite. He also mentions the following inedita: two dedications of votive reliefs depicting a hand by a certain Zoilos, one to Zeus, the other to Artemis; a dedication to Apollo Agyieus; and a dedication to Zeus Soter by a former agonothetes (3rd cent).

123) S.R. токHTASIEv, "De nouvelles données sur l'histoire de la koiné dans le Nord de la Mer Noire", in G. votTÉRo (ed.), Le grec du monde colonial antique. I.Le N. et N.-O. de la Mer Noire. Actes de la Table ronde de Nancy, 28-29 septembre 2007, Nancy, 2009, p. 33-49 [SEG LIX 844]: Ed. pr. of an inscription from Pantikapaion (1st cent. CE, p. 36 note 11). The text is

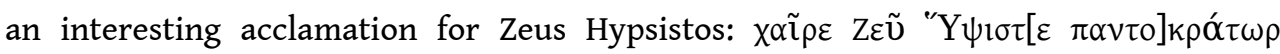

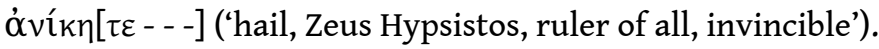

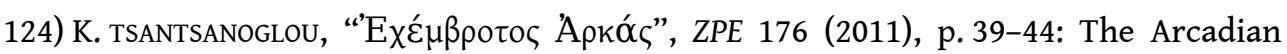
Echembrotos won the aulodic contest in the first Pythia in 586 BCE. However, after his victory the competition in this discipline was abolished. Echembrotos dedicated the prize, a tripod, to Herakles in Thebes. The metrical structure of his dedicatory epigram, known from Pausanias $(X 7,6)$, has puzzled scholars. T. proposes an emendation of the

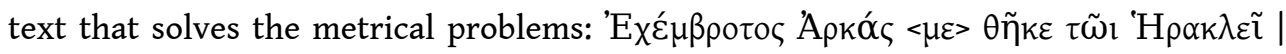

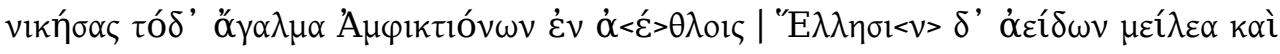
$\dot{\varepsilon} \lambda \dot{\varepsilon}$ youc. According to this emendation, the poem consisted of an iambic trimeter followed by an elegiac distich. Such a combination characterized amusing and witty poetry. Echembrotos' joke consisted in dedicating the tripod that he had won in Delphi to Herakles in Thebes. In this way he alluded to the famous mythological quarrel between Apollo and Herakles in Delphi, when Herakles tried to snatch Apollo's propetic tripod. Since the sanctuary of Herakles in Thebes bordered that of Apollo Ismenios, the provocation was more obvious. The dedication was made as an act of bitter resentment against the decision of the Amphiktyones who regarded aulody as mournful and

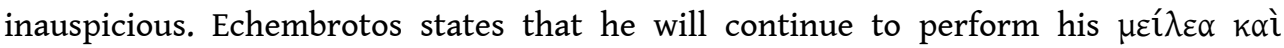
$\dot{\varepsilon} \lambda \varepsilon$ you before all the Greeks. Echembrotos' wit is also expressed in the poem's

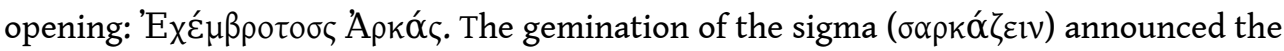
poet's origins and the ironical and scornful nature of his poem.

125) E.B. TSIGARIDA, "The Sanctuary of Zeus Ammon at Kallithea (Chalkidike)", Kernos 24 (2011), p. 165-181: T. summarizes the history of an important sanctuary at Kallithea 
(Chalkidike). A cult of Dionysos and the Nymphs was practiced in a cave from the late 8th cent. Fragments of vases inscribed with the name of the god have made the identification of the cult possible. The cult of Zeus Ammon was introduced in the early 4th cent., followed by the introduction of the cult of Asklepios (SEG XLIII 353); the existence of water resources was important for all these cults.

126) G. VAlLARINO, "Nikandre e Nausicaa: due korai archaiche", in Epigrammata -- Susini, p. 331-344 [BE 2012, 51]: V. presents an excellent analysis of the metrical dedication on the statue of the Naxian Nikandre dedicated to Artemis in Delos (I.Délos 2; IG XII. 5.1425b; CEG 403; ca. 625-600). The text is arranged in such a manner that a reader

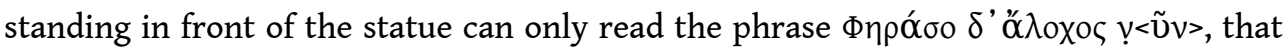
is, a phrase that highlights Nikandre's status as a wife. Her statue was probably dedicated on the occasion of her wedding commemorating her passage from the status

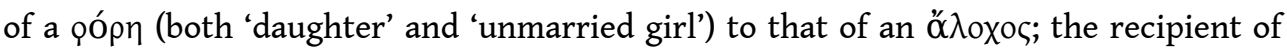
the dedication, Artemis, is a patron of women. The text is closely connected with the encounter between Nausikaa and Odysseus (Odyssey 6.102-109 and 145-159). In both texts Artemis is called ioxéaıpo. Nausikaa is compared with Artemis, the goddess to whom Nikandre made her dedication. In the epigram, Nikandre's social position is

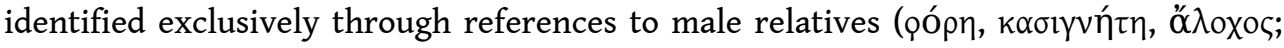
similarly, in his praise of Nausikaa Odysseus refers to her father and brothers, and

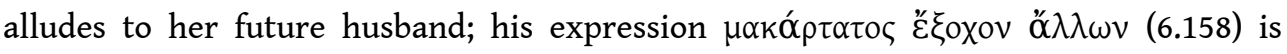
paralleled by $\varepsilon$ $\xi o x \circ \varsigma \dot{\alpha} \lambda$ ńov in Nikandre's epigram. Finally, Odysseus refers to Delos, the place of Nikandre's dedication, when he states that only a young branch of the palm tree near the altar of Apollo in Delos surpassed Nausikaa's beauty. This Homeric scene served as the ideological and literary model for Nikandre's poem, who dedicated her statue to Artemis, after her wedding, representing herself as a new Nausikaa.

127) P. van MinNen, "Contracting Caterers on Keos", in Myths, Martyrs, and Modernity, p. 209-218: A cult regulation from Koresia on Keos (IG XII.5.647 = LSCG 98, late 3rd/early 2nd cent.) provides information on the practicalities of the organization of a festival and the banquet at the end of the year. Rejecting R. OSBORNE's understanding of the text as evidence for how sacrifice reinforced the social structure of the city (Classical Landscape with Figures, London, 1987, p. 180f.), getting the victims from its territory and distributing the meat to those who are important to the city, v.M. discusses in detail the clauses and translates the text. As v.M. points out, O. omitted the first lines, which refer to the duty of the chief magistrates in office to 'contract' ( $\dot{\varepsilon} \gamma \delta_{1} \delta$ óval) with an individual who would provide the victims and other foodstuffs for the festival. There is no indication that the meat had to come from the island; the caterer might have come from Athens, with which Keos had close contacts; the inscription was cut by an Athenian mason (S.V. TRACY, Attic Letter-Cutters of 229 to 86 B.C., Berkeley, 1990, p. 66). The text does not prescribe the sacrifice of only one mature ox and one sheep as Osborne and other scholars assumed. It simply states that any ox and any female sheep he slaughtered had to be mature; if he slaughtered a pig, it had to be older than 18 months. The caterer must have estimated the amount of meat needed in Koresia (and possibly other cities that celebrated a festival at the same time) and provided it. 'He had to provide a feast for the citizens, for those invited by the city, for resident foreigners and all freemen who pay their taxes to Koresia' (Osborne's translation: 'and for all that pay taxes to Koresia'); the text also mentions other foodstuffs to be used during the feast. All the entrails were consumed (not 'part of the entrails'). The text 
lists the responsibilities of the magistrates in the examination of the victims and

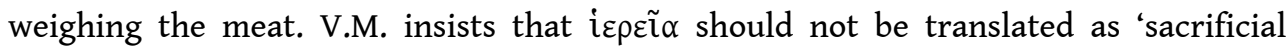

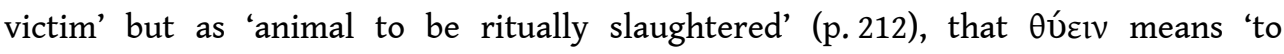
slaughter', not 'to sacrifice' (since the caterer could not perform a religious ritual; p. 213), and that $\tau \tilde{\omega} v$ i $\varepsilon \rho \tilde{\omega} v \pi \rho \circ \hat{i} \sigma \tau \alpha \sigma \theta \alpha \mathrm{l}$ means that the chief magistrates performed

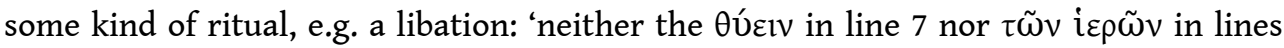
15-16 have anything to do with sacrifice' (p. 215; Osborne's translation: 'preside at the sacrifice'). The caterer served the evening meal until sunset, and if he performed all the duties as agreed, he received the rest of his payment. The text is an 'administrative law', not a law about sacrifice. [v.M. is right in the assumption the caterer did not perform a sacrifice himself; it is also striking that no god is mentioned; but $\tau \tilde{\omega} v i \varepsilon \rho \tilde{\omega} v$ $\pi p o i ́ \sigma \tau \alpha \sigma \theta \alpha$ l probably means more than 'say grace' (p. 215), rather: 'preside over the

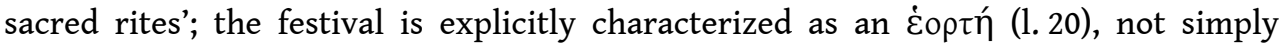
$\pi \alpha v \eta$ үupıৎ or $\dot{\varepsilon} \sigma \tau i \alpha \sigma ı \zeta$; it is a religious festival; the lack of reference to a particular god can easily be explained if this decree supplements an existing law. The law was not

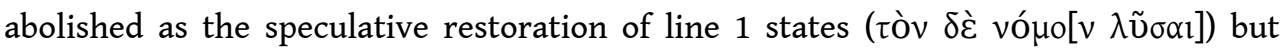
probably confirmed and supplemented with additional measures concerning the supply of animals].

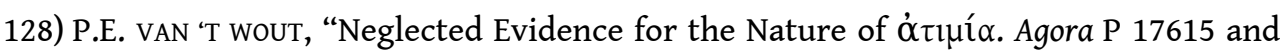
DTA 107", ZPE 176 (2011), p. 126-134: The author discusses an Attic judiciary defixio that

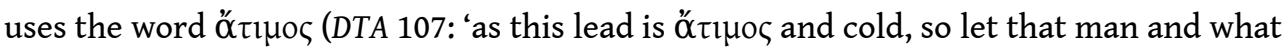
belongs to him be ö $\tau 1 \mu \alpha$ and cold'; 5th/4th cent.). A comparison with other curse tablets leads to the conclusion that the intended effect was the victim's inability to manifest himself successfully as a litigant (cf. Aristophanes, Wasps 946).

129) J. VERDEJO MANCHADO, B. ANTELA-BERNÁRDEZ, "IG II ${ }^{2}$ 1334: A Crown for Onaso and the Archon Athenion", ZPE 177 (2011), p. 91-96: The authors republish with detailed commentary the honorific decree of a cult association (orgeones) of Meter Theon for the priestess Onaso ( $I G \mathrm{II}^{2} 1334$, ca. $70 \mathrm{BCE}$ ). The text gives a summary of the duties of the priestess (selection by lot, care for order in the sanctuary, offering sacrifices). Onaso served twice as priestess, the second time during the archonship of Athenion, whom the authors identify as the Athenian supporter of Mithridates VI. [Both the restoration [A] $\theta_{\eta} \eta i^{\prime} \omega v O \zeta$ and the proposed identification are plausibly rejected by S.V. TRACY, "Line 6 of IG II 1334 Revisited", ZPE 179 (2011), p. 139-140].

130) D. VIVIERS, “Élites et processions dans les cités. Une géometrie variable?", in La cité et ses élites, p. 163-181: V. reflects on the social and political importance of religious processions in Greek cities, pointing to the large variety of criteria applied for the participation and position of individuals. He stresses that processions did not only serve the prestige of the rich but also expressed order, social cohesion (e.g. the Panathenaic procession), and concord. He addresses the following aspects: 1) Rank:

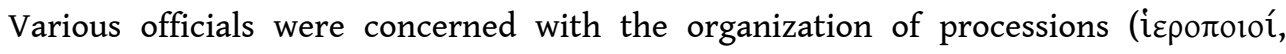

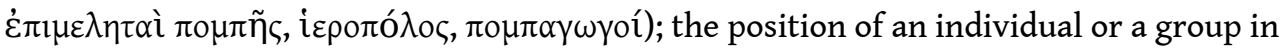
a procession was subject to diverse criteria, ranging from function or social rank to tribal membership (e.g. IG II $334=$ LSCG 33; IG I3 82 = LSCG 13; I.Ilion 52 = LSAM 9; IG V. 1.1390; F.Delphes III.3.238 = LSCG Suppl. 44; I.Ilion 31; I.Ilion 52 = LSAM 9). In this context, V. summarizes the content of a still unpublished inscription from Itanos on Crete (1st cent.); it lists the names of a chorus of ten girls led by the priestess of Leukothea, who was accompanied by two attendants; the chorus participated in a procession in honor 
of Leukothea in exactly the order in which their names appeared on the inscription

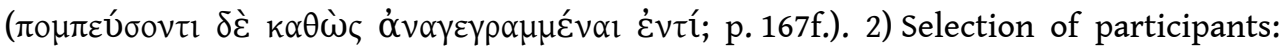
The selection of participants was a strategy of social distinction; the modes of selection varied (by lot, ancestry, physical beauty and strength, etc.), reflecting certain aspects of a community's ideology (references to: IG V.1.1390; I.Ilion 52; IG II ${ }^{2}$ 1006; IG XII.9.194). [On Hellenistic processions see now A. CHANIOTIS, "Processions in Hellenistic Cities: Contemporary Discources and Ritual Dynamics", in R. ALSTON, O.M. VAN NIJF, C.G. WiLliamson (eds.), Cults, Creeds and Contests, Louvain, 2013, p. 21-47].

131) J. wallensten, J. PAKKANen, "A New Inscribed Statue Base from the Sanctuary of Poseidon at Kalaureia", OAth 2 (2009), p. 155-165 [SEG LX 367]: Ed. pr. of an inscribed statue base from the sanctuary of Poseidon at Kalaureia (ca. 270-246 BCE?). The inscription records the dedication to Ptolemy II and Arsinoe to Poseidon; the dedicant was the city of Methana, renamed to Arsinoe. The authors suggest a date after Arsinoe's death and during the Chremonidean War.

132) B.L. WICKKISER, "IG II 4963 and the priesthood of Asklepios in Athens", ZPE 179 (2011), p. 123-125 [BE 2012, 163]: A fragmentary inscription from Athens records building activity in the sanctuary of Asklepios ( $\mathrm{IG} \mathrm{II}^{2}$ 4963, ca. 400-350). W. observes

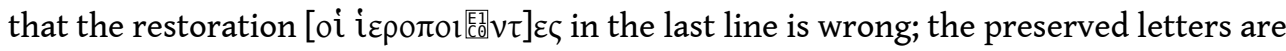
$\Xi I \Sigma$; also this line is separated with a vacat from the rest of the text and was written later. Consequently, this text cannot be used as the (only) proof for the appointment of hieropoioi by the state.

133) P. WILSON, "How Did the Athenian Demes Fund their Theatre?", in L'argent dans les concours, p. 37-82: Theatrical performances at the Dionysia organized by the Athenian demes were a very elaborate and expensive activity. Of the 18 deme Dionysia for which evidence exists 15 included theatrical events. Small demes, with quota of fewer than 3 bouleutai, presumably did not organize theatrical performances. The most important method of funding was the choregia, attested in 11 demes, usually in the form of collaboration between family members who jointly contributed the funds (synchoregia). Information is provided by honorific decrees for choregoi (e.g. from the deme of the Aixoneis: IG II ${ }^{2} 1198,1200,1202$; SEG XXXVI 186). Also men who were not demesmen occasionally served as choregoi. Honorific inscriptions for both demarchoi and choregoi (e.g. IG II ${ }^{2} 1173,1178$ ) show that the deme's officials and the choregoi collaborated in the organization of the festival. Demarchoi sometimes contributed private funds for the festivities (I.Eleusis 101, for a sacrifice). Additional funding came from the deme's funds (e.g. in Ikarion: $I G I^{3} 253$ ) and from revenues from the leasing of theaters (Piraeus: Agora XIX L13; Acharnai: IG II ${ }^{2} 1206$, for which see EBGR 2007, 106; cf. the security horos IG II ${ }^{2}$ 2767, which mentions Dionysos as beneficiary, possibly of the leasing of a theatre in Hagnous). W. argues that a fragmentary decree from Thorikos (SEG XXXIV 107; cf. EBGR $2007,146)$ established a kind of auction of the right to serve as choregos, that is, turning the appointment of the choregos to a contest in benefaction (cf. IG I 254 lines 1-5); these choregoi funded all the dramatic productions of a single festival and not a single chorus (cf. IG $\mathrm{I}^{3} 258$ bis and SEG XXXIV 174). In an appendix, W. discusses two decrees of Acharnai (SEG XLIII $26 \mathrm{~A}$ and B, 315/4 BCE) as evidence for the interventions of the city of Athens in the local Dionysia during the regime of Demetrios of Phaleron. The city appointed an epimeletes of the Dionysia and the local treasurer also handled funds provided by both deme and city; the surplus of this joint budget was kept by the deme. 
310 134) P. WILSON, “Dionysos in Hagnous”, ZPE 177 (2011), p. 79-89: The fragmentary decree of the demos Hagnous in Athens (IG II $^{2} 1183$, ca. 325-300) includes inter alia provisions to permit deme priests to offer loans on the security of real estate (lines 27-32; on p. 84f., discussion of possible restorations). The name of the god whose money had been offered was to be inscribed on the security marker-stone placed in the mortgaged property. If the priest failed to place the marker-stone, he would be personally responsible for any money lost and his property would be mortgaged. W. identifies in

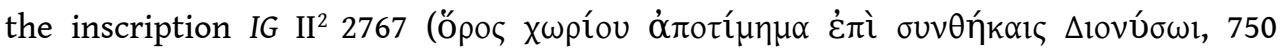
drachmas) such a marker-stone from Hagnous for a loan given under the conditions of the deme decree. The cult of Dionysos was prominent in this deme (cf. IG II ${ }^{2} 1183$ on the local Dionysia). In an Appendix (p. 85-87), W. discusses the provisions for the distribution of sacrificial meat after the sacrifice at the festival Plerosia: $\tau$ ĩ $\varsigma \pi[\alpha \rho o \tilde{\sigma} \sigma \mathrm{lv}$

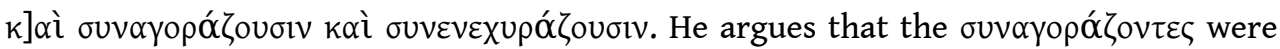
large-scale purchasers of produce welcomed to the festival to which a market-fair was

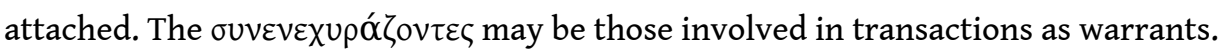

135) M. WÖRRLE, "Neue Inschriftenfunde aus Aizanoi VI: Aizanoi und Rom II", Chiron 41 (2011), p. 357-376 [BE 2012, 406]: Improved edition of a fragmentary letter of the proconsul C. Norbannus Flaccus to Aizanoi (MAMA IX 13). The proconsul reports that the envoys of Aizanoi had given him a letter of an emperor (probably Augustus), who allowed them to hold an assembly in order to discuss the grant of tax exemption to the priest of an undetermined cult; this would compensate him for the burden of

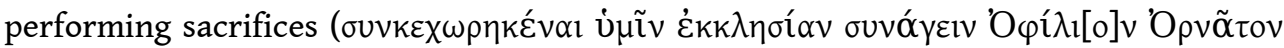

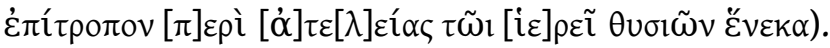

136) M. WÖRRLE, "Epigraphische Forschungen zur Geschichte Lykiens X: Limyra in seleukidischer Hand", Chiron 41 (2011), p. 377-415 [BE 2012, 397]: Ed. pr. of an important document from Limyra, a letter of an official in the service of Antiochos III responding to an embassy of the city (ca. 197-189). Although the letter deals with problems arising from the presence of Seleucid troops, it contains an important piece of information

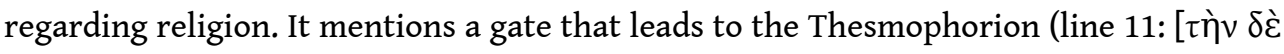

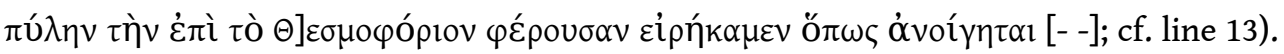
This is the only attestation of a Thesmophorion in Lykia and it suggest that the cult of Demeter Thesmophoros must have been imported relatively early in the Hellenistic period. The text refers to the Thesmophorion only in connection with a gate that the Seleucid troops kept closed. Following the general pattern, the Thesmophorion was located outside the city-wall. In an appendix, W. publishes a fragmentary dedicatation made by a priest to Demeter Thesmophoros; the text refers to $\dot{\eta} \mu i ́ \theta \varepsilon o 1$. 


\section{AUTHOR}

\section{ANGELOS CHANIOTIS}

School of Historical Studies Institute for Advanced Study

Einstein Drive

Princeton, NJ 08540

achaniotis@ias.edu 